\title{
Pathophysiology and Therapeutic Potential of Purinergic Signaling
}

\author{
GEOFFREY BURNSTOCK \\ Autonomic Neuroscience Centre, Royal Free and University College Medical School, London, United Kingdom
}

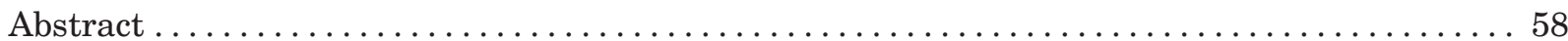

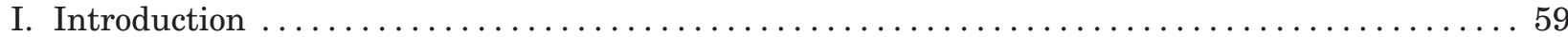

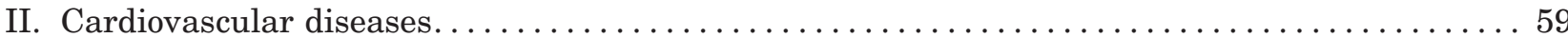

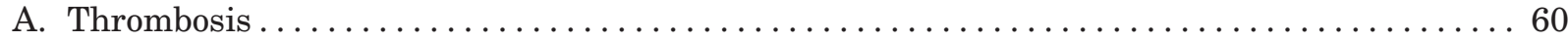

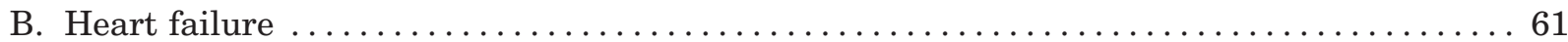

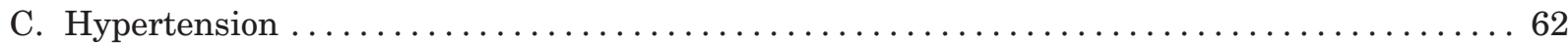

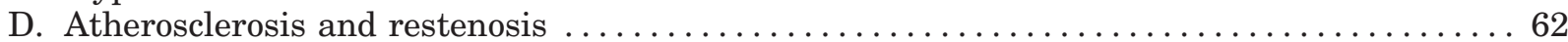

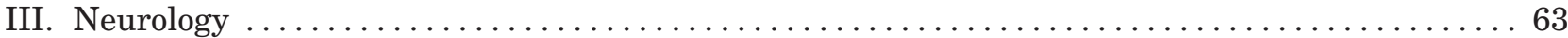

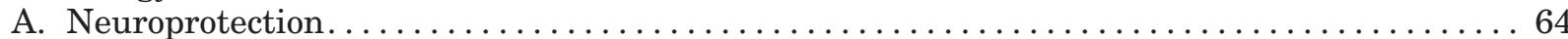

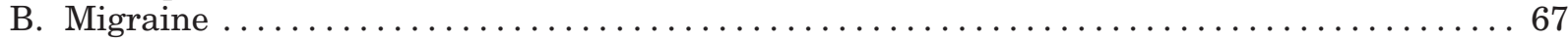

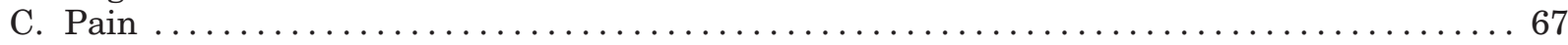

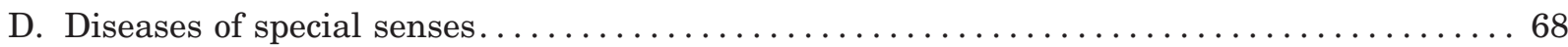

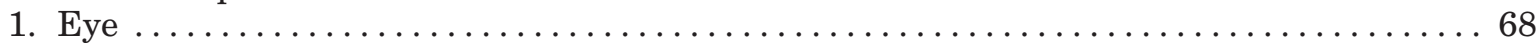

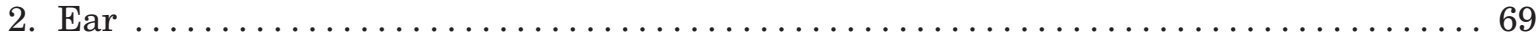

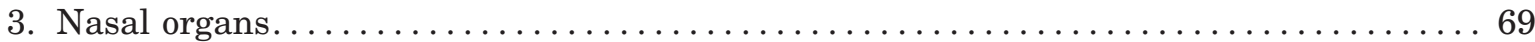

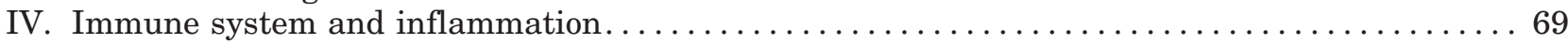

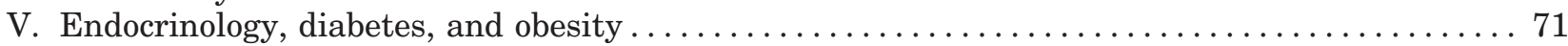

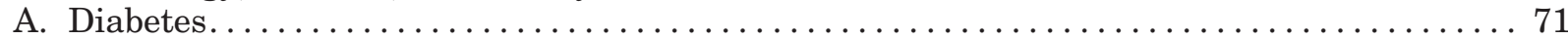

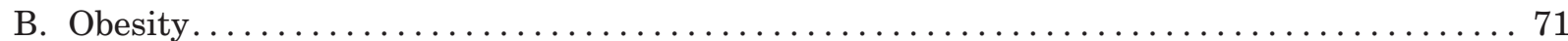

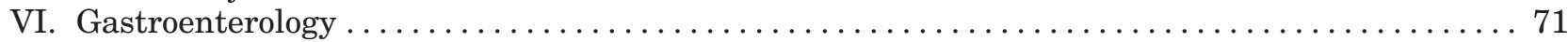

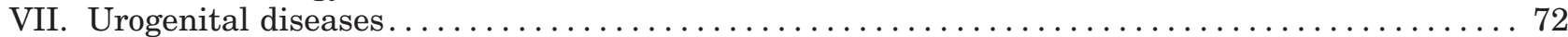

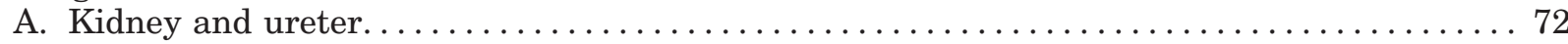

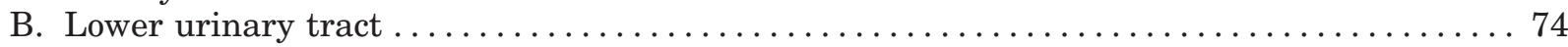

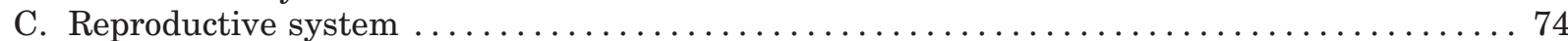

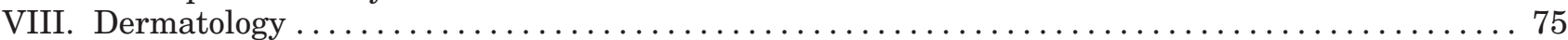

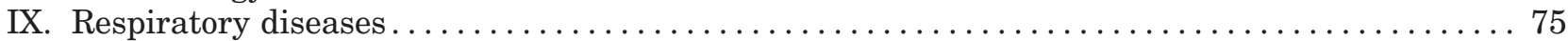

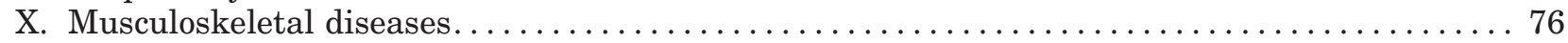

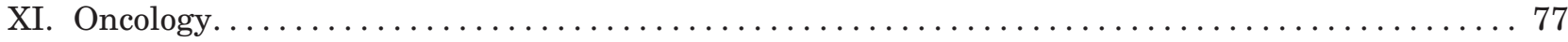

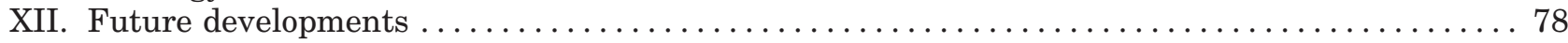

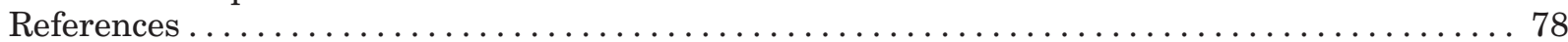

\begin{abstract}
The concept of a purinergic signaling system, using purine nucleotides and nucleosides as extracellular messengers, was first proposed over 30 years ago. After a brief introduction and update of purinoceptor subtypes, this article focuses on the diverse pathophysiological roles of purines and pyrimidines as signaling molecules. These molecules mediate short-term (acute) signaling functions in neurotransmission, mechanosensory transduction, secretion and vasodilatation,
\end{abstract}

and long-term (chronic) signaling functions in cell proliferation, differentiation, and death involved in development and regeneration. Plasticity of purinoceptor expression in pathological conditions is frequently observed, including an increase in the purinergic component of autonomic cotransmission. Recent advances in therapies using purinergic-related drugs in a wide range of pathological conditions will be addressed with speculation on future developments in the field.

Address correspondence to: Prof. Geoffrey Burnstock, Autonomic Neuroscience Centre, Royal Free and University College Medical School, London NW3 2PF, UK. E-mail: g.burnstock@ucl.ac.uk

Article, publication date, and citation information can be found at http://pharmrev.aspetjournals.org.

doi:10.1124/pr.58.1.5. 


\section{Introduction}

A seminal article by Drury and Szent-Györgi in 1929 described the potent actions of purine nucleotides and nucleosides, ATP, and adenosine on the heart and blood vessels. Then, in 1970, evidence was presented for ATP as a neurotransmitter in nonadrenergic, noncholinergic $\left(\mathrm{NANC}^{1}\right)$ nerves supplying the gut (Burnstock et al., 1970) and in 1972 the word "purinergic" was coined and the purinergic neurotransmission hypothesis was proposed by Burnstock (Burnstock, 1972). This concept met with considerable resistance for many years, because ATP had been established as an intracellular energy source involved in various metabolic cycles, and it was thought that such a ubiquitous molecule was unlikely to be involved in selective extracellular signaling. However, the concept is now widely accepted. Later, it was established that ATP was a cotransmitter with classic transmitters in both the peripheral and central nervous systems and that purines are also powerful extracellular messengers to non-neuronal cells, including exocrine and endocrine, secretory, endothelial, musculoskeletal, immune, and inflammatory cells (Burnstock and Knight, 2004).

Implicit in the purinergic hypothesis was the presence of purinoceptors (Ralevic and Burnstock, 1998). A basis for distinguishing P1 (adenosine) from P2 (ATP/ADP) receptors was proposed by Burnstock in 1978. This helped resolve some of the ambiguities in earlier reports, which were complicated by the breakdown of ATP to adenosine by ectoenzymes so that some of the actions of ATP were directly on P2 receptors, whereas others were due to indirect action via $\mathrm{P} 1$ receptors. Four subtypes of $\mathrm{P} 1$ receptors were cloned, namely, $\mathrm{A}_{1}, \mathrm{~A}_{2 \mathrm{~A}}, \mathrm{~A}_{2 \mathrm{~B}}$, and $\mathrm{A}_{3}$. In 1985, Burnstock and Kennedy proposed a basis for distinguishing two types of P2 purinoceptor, namely, P2X and P2Y, based largely on pharmacological criteria. In the early 1990s, studies of transduction mechanisms and cloning of both $\mathrm{P} 2 \mathrm{X}$ and $\mathrm{P} 2 \mathrm{Y}$ receptors were carried out, which led Abbracchio and Burnstock to put forward a new nomenclature system in 1994, which is now widely accepted (Fredholm et al., 1994; Schwiebert, 2003). They proposed that there were two families of P2 receptors, namely, P2X ionotropic ligand-gated ion channel receptors and P2Y metabotropic G protein-coupled receptors. This framework has allowed a logical expan-

\footnotetext{
${ }^{1}$ Abbreviations: NANC, nonadrenergic, noncholinergic; NO, nitric oxide; E-NTPDase, ectonucleoside triphosphate diphosphohydrolase; NA, noradrenaline; DRG, dorsal root ganglia; PPADS; pyridoxal-5' phosphate-6-azophenyl-2',4' disulfonic acid; TNP, trinitrophenyl; NMDA, $N$-methyl-D-aspartate; AIT-082, 4-[[3-(1,6-dihydro-6-oxo-9purin-9-yl)-1-oxopropyl]amino] benzoic acid; LTP, long-term potentiation; NTS, nucleus tractus solitarius; $\mathrm{Ap}_{4} \mathrm{~A}$, diadenosine tetraphosphate; IL, interleukin; COX, cyclooxygenase; CNS, central nervous system; IB4, isolectin B4; IBD, inflammatory bowel disease; MRS2500, 2-iodo- $N^{6}$-methyl-( $\left.N\right)$-methanocarba-20-deoxyadenosine30,50-bisphosphate; A-317491, 5-([(3-phenoxybenzyl)[(1S)-1,2,3,4tetrahydro-1-naphthalenyl] amino]carbonyl)-1,2,4-benzenetricarboxylic acid; INS37217, $\mathrm{P}_{1}$-(uridine $\left.5^{\prime}\right)-\mathrm{P}_{4}$-(2'-deoxycytidine $\left.5^{\prime}\right)$ tetraphosphate, tetrasodium salt.
}

sion as new receptors were identified. Currently seven subtypes of P2X receptors and eight subtypes of $\mathrm{P} 2 \mathrm{Y}$ receptors are clearly established (Table 1$)$. It is recognized that the pyrimidine UTP is equipotent with ATP at $\mathrm{P} 2 \mathrm{Y}_{2}$ and $\mathrm{P} 2 \mathrm{Y}_{4}$ receptors and $\mathrm{UDP}$ is a potent agonist at $\mathrm{P} 2 \mathrm{Y}_{6}$ receptors. The distribution and functional roles of $\mathrm{P} 2$ receptors in many cell types in the body have been described (Burnstock and Knight, 2004).

Purinergic signaling is rapid in synaptic neurotransmission, in neuromuscular transmission leading to contraction or relaxation of smooth muscle, and in exocrine or endocrine secretion. However, there are now many examples of purinergic signaling regulating long-term events such as cell proliferation, differentiation, migration, and death in development, regeneration, and wound healing. Both P2X and $\mathrm{P} 2 \mathrm{Y}$ receptors play prominent roles both directly and by modulation of other signaling systems in embryonic development, including the nervous system, cartilage in limb buds, the mesonephros, retina, myotubes, and neuromuscular junctions (Burnstock, 2001a).

There is increasing interest in the therapeutic potential of purinergic compounds (including receptor agonists and antagonists, ectoenzyme inhibitors and enhancers, and ATP transport inhibitors and enhancers) in a wide range of disease conditions in relation to both $\mathrm{P} 1$ and $\mathrm{P} 2$ receptors. A number of purine-related compounds have been patented. The autonomic nervous system shows marked plasticity. Dramatic changes occur in the expression of cotransmitters and receptors during development and aging, in nerves that remain after trauma or surgery and in disease conditions. There are several pathological conditions in which the purinergic component of cotransmission is increased (Burnstock, 2002b). The emphasis in this article is on the pathophysiology and therapeutic potential of P2 receptors (see also Burnstock and Williams, 2000; Boeynaems et al., 2001; Yerxa, 2001; Burnstock, 2002a; Jacobson et al., 2002; Ralevic and Burnstock, 2003) and readers are referred to recent reviews about the therapeutic potential of $\mathrm{P} 1$ receptors (Fredholm et al., 2002, 2005; Okusa, 2002; Pelleg et al., 2002; Dhalla et al., 2003; Ribeiro et al., 2003; Hutchinson and Scammells, 2004; McCallion et al., 2004).

\section{Cardiovascular Diseases}

ATP and adenosine are very much involved in the mechanisms underlying local control of vessel tone (Burnstock and Ralevic, 1994) (Fig. 1) as well as cell migration, proliferation, differentiation, and death during angiogenesis, atherosclerosis, and restenosis following angioplasty (Erlinge et al., 1998; Burnstock, 2002b). ATP, released as a cotransmitter from sympathetic nerves, constricts vascular smooth muscle via P2X receptors, whereas ATP released from sensory-motor nerves during "axon reflex" activity dilates or constricts 
TABLE 1

Characteristics of purine-mediated receptors

Table modified from Burnstock (2003a), with permission from Elsevier (New York, NY).

\begin{tabular}{|c|c|c|c|c|}
\hline Receptor & Main Distribution & Agonists & Antagonists & Transduction Mechanisms \\
\hline \multicolumn{5}{|l|}{ P2X } \\
\hline $\mathrm{P} 2 \mathrm{X}_{1}$ & $\begin{array}{l}\text { Smooth muscle, platelets, } \\
\text { cerebellum, dorsal horn spinal } \\
\text { neurones }\end{array}$ & $\begin{array}{l}\alpha, \beta-\text { meATP }=\text { ATP }=2 \text {-MeSATP } \\
\quad(\text { rapid desensitization })\end{array}$ & TNP-ATP, IP $_{5} \mathrm{I}, \mathrm{NF} 023, \mathrm{NF} 449$ & $\begin{array}{l}\text { Intrinsic cation channel }\left(\mathrm{Ca}^{2+}\right. \\
\left.\text { and } \mathrm{Na}^{+}\right)\end{array}$ \\
\hline $\mathrm{P} 2 \mathrm{X}_{2}$ & $\begin{array}{l}\text { Smooth muscle, CNS, retina, } \\
\text { chromaffin cells, autonomic } \\
\text { and sensory ganglia }\end{array}$ & $\begin{array}{l}\text { ATP } \geq \text { ATP } \gamma \mathrm{S} \geq 2 \text {-MeSATP } \gg \\
\alpha, \beta \text {-meATP }(\mathrm{pH}+\text { zinc- } \\
\text { sensitive })\end{array}$ & $\begin{array}{l}\text { Suramin, isoPPADS, RB2, } \\
\quad \text { NF770 }\end{array}$ & $\begin{array}{l}\text { Intrinsic ion channel } \\
\quad\left(\text { particularly } \mathrm{Ca}^{2+}\right)\end{array}$ \\
\hline $\mathrm{P} 2 \mathrm{X}_{3}$ & $\begin{array}{l}\text { Sensory neurons, NTS, some } \\
\text { sympathetic neurones }\end{array}$ & $\begin{array}{l}\text { 2-MeSATP } \geq \mathrm{ATP} \geq \alpha, \beta- \\
\text { meATP } \geq \mathrm{Ap}_{4} \mathrm{~A} \text { (rapid } \\
\text { desensitization) }\end{array}$ & $\begin{array}{l}\text { TNP-ATP, PPADS, A317491, } \\
\text { NF110 }\end{array}$ & Intrinsic cation channel \\
\hline $\mathrm{P}_{2} \mathrm{X}_{4}$ & CNS, testis, colon & $\begin{array}{l}\mathrm{ATP} \gg \alpha, \beta \text {-meATP; CTP, } \\
\text { Ivermectin }\end{array}$ & TNP-ATP (weak), BBG (weak) & $\begin{array}{l}\text { Intrinsic ion channel (especially } \\
\left(\mathrm{Ca}^{2+} \text { ) }\right.\end{array}$ \\
\hline $\mathrm{P} 2 \mathrm{X}_{5}$ & $\begin{array}{l}\text { Proliferating cells in skin, gut, } \\
\text { bladder, thymus, spinal cord }\end{array}$ & $\mathrm{ATP} \gg \alpha, \beta$-meATP; ATP $\gamma \mathrm{S}$ & Suramin, PPADS, BBG & Intrinsic ion channel \\
\hline $\mathrm{P} 2 \mathrm{X}_{6}$ & $\begin{array}{l}\text { CNS, motor neurones in spinal } \\
\text { cord }\end{array}$ & $\begin{array}{l}\text { Does not function as } \\
\text { homomultimer }\end{array}$ & & Intrinsic ion channel \\
\hline $\mathrm{P} 2 \mathrm{X}_{7}$ & $\begin{array}{l}\text { Apoptotic cells in, for example, } \\
\text { immune cells, pancreas, skin }\end{array}$ & $\begin{array}{l}\text { BzATP }>\text { ATP } \\
\alpha, \beta \text {-meATP }\end{array}$ & $\begin{array}{l}\text { KN62, KN04, MRS2427, } \\
\text { Coomassie brilliant blue G }\end{array}$ & $\begin{array}{l}\text { Intrinsic cation channel and a } \\
\text { large pore with prolonged } \\
\text { activation }\end{array}$ \\
\hline \multicolumn{5}{|r|}{ activation the the the } \\
\hline $\mathrm{P}_{2} \mathrm{Y}_{1}$ & $\begin{array}{l}\text { Epithelial and endothelial cells, } \\
\text { platelets, immune cells, } \\
\text { osteoclasts }\end{array}$ & $\begin{array}{l}\text { 2-MeSADP > 2-MeSATP }=\text { ADP } \\
\quad>\text { ATP; MRS2365 }\end{array}$ & MRS2179, MRS2500 & $\mathrm{G}_{\mathrm{q}} / \mathrm{G}_{11} ;$ PLC- $\beta$ activation \\
\hline $\mathrm{P}_{2} \mathrm{Y}_{2}$ & $\begin{array}{l}\text { Immune cells, epithelial and } \\
\text { endothelial cells, kidney } \\
\text { tubules, osteoblasts }\end{array}$ & $\mathrm{UTP}=\mathrm{ATP}, \mathrm{UTP} \gamma \mathrm{S} ;$ INS 37217 & Suramin > RB2 ARC126313 & $\begin{array}{l}\mathrm{G}_{\mathrm{q}} / \mathrm{G}_{11} \text { and possibly } \mathrm{G}_{\mathrm{i}} ; \text { PLC- } \beta \\
\quad \text { activation }\end{array}$ \\
\hline $\mathrm{P}_{2} \mathrm{Y}_{4}$ & Endothelial cells & $\mathrm{UTP} \geq \mathrm{ATP}, \mathrm{UTP} \gamma \mathrm{S}$ & $\mathrm{RB} 2>$ suramin & $\begin{array}{l}\mathrm{G}_{\mathrm{q}} / \mathrm{G}_{11} \text { and possibly } \mathrm{G}_{\mathrm{i}} ; \text { PLC- } \beta \\
\text { activation }\end{array}$ \\
\hline $\mathrm{P}_{2} \mathrm{Y}_{6}$ & $\begin{array}{l}\text { Some epithelial cells, placenta, } \mathrm{T} \\
\text { cells, thymus }\end{array}$ & $\mathrm{UDP}>\mathrm{UTP} \gg \mathrm{ATP} ; \mathrm{UDP} \beta \mathrm{S}$ & MRS2578 & $\mathrm{G}_{\mathrm{q}} / \mathrm{G}_{11} ;$ PLC- $\beta$ activation \\
\hline $\mathrm{P} 2 \mathrm{Y}_{11}$ & Spleen, intestine, granulocytes & $\begin{array}{l}\text { ARC67085MX }>\text { BzATP } \\
\quad \geq \operatorname{ATP} \gamma \mathrm{S}>\text { ATP }\end{array}$ & Suramin $>$ RB2, NF157 & $\mathrm{G}_{\mathrm{q}} / \mathrm{G}_{11}$ and $\mathrm{G}_{\mathrm{S}} ;$ PLC- $\beta$ activation \\
\hline $\mathrm{P} \mathrm{Y}_{12}$ & Platelets, glial cells & 2-MeSADP $\geq \mathrm{ADP} \gg \mathrm{ATP}$ & $\begin{array}{l}\text { CT50547, ARC69931MX, } \\
\text { INS49266, AZD6140, } \\
\text { PSB0413 }\end{array}$ & $\begin{array}{l}\mathrm{G}_{\mathrm{i}}\left(\mathrm{G}_{\mathrm{o}}\right) ; \text { inhibition of adenylate } \\
\text { cyclase }\end{array}$ \\
\hline $\mathrm{P} \mathrm{Y}_{13}$ & $\begin{array}{l}\text { Spleen, brain, lymph nodes, } \\
\text { bone marrow }\end{array}$ & $\begin{array}{l}\mathrm{ADP}=2-\mathrm{MeSADP} \gg \mathrm{ATP} \text { and } \\
\text { 2-MeSATP }\end{array}$ & MRS2211 & $\mathrm{G}_{\mathrm{i}} / \mathrm{G}_{\mathrm{o}}$ \\
\hline $\mathrm{P} \mathrm{Y}_{14}$ & $\begin{array}{l}\text { Placenta, adipose tissue, } \\
\text { stomach, intestine, discrete } \\
\text { brain regions }\end{array}$ & UDP glucose = UDP-galactose & & $\mathrm{G}_{\mathrm{q}} / \mathrm{G}_{11}$ \\
\hline
\end{tabular}

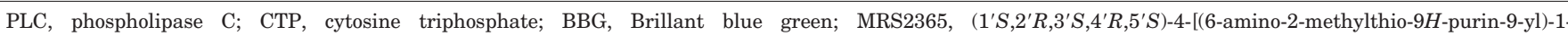

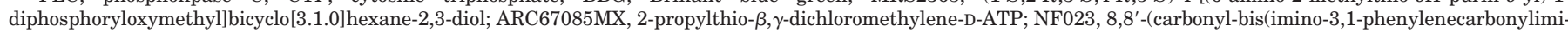

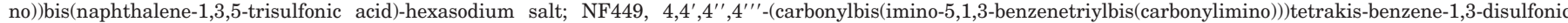

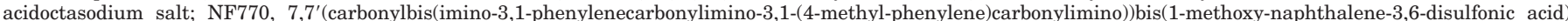

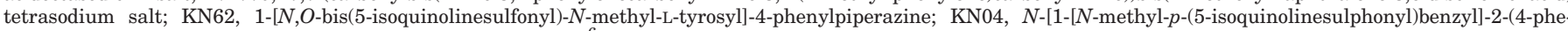

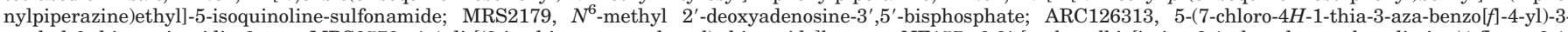

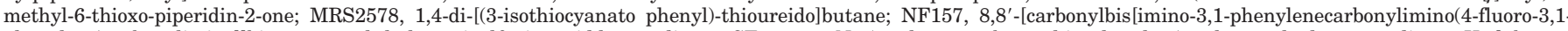

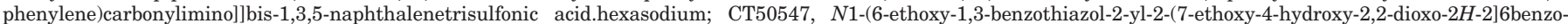

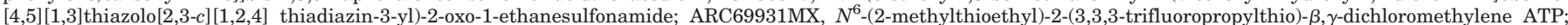

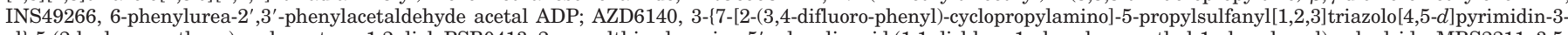

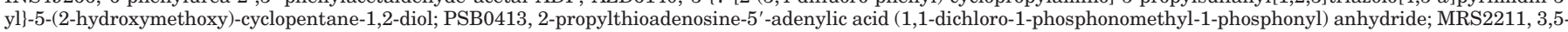
diethyl-2-methyl-4-(trans-2-(4-nitrophenyl)vinyl)-6-phenyl-1,4-dihydropyridine-3,5-dicarboxilate.

some vessels. Furthermore, ATP released from endothelial cells during changes in flow (shear stress) or hypoxia acts on P2Y receptors in endothelial cells to release nitric oxide (NO), resulting in relaxation. Adenosine produced by the breakdown of extracellular ATP causes vasodilatation via smooth muscle $\mathrm{P} 1$ receptors. $\mathrm{P} 2 \mathrm{X}$ receptors are also present on endothelial cells and appear to be associated with cell adhesion and permeability. ATP release from red blood cells is increased in pathological conditions such as subarachnoid hemorrhage, largely because there is widespread blood cell lysis (Sprague et al., 2003). This leads to transient constriction of arterioles via P2X receptors and sustained constriction of large cerebral vessels, largely through $\mathrm{P}_{2} \mathrm{Y}_{2}$ receptors. The differences in purinergic receptor distri- bution between macro- and microvessels in the cerebral circulation are likely to have important consequences in pathological conditions.

\section{A. Thrombosis}

There have been very promising developments concerning purinergic antithrombotic drugs. Platelets are known to express $\mathrm{P} 2 \mathrm{Y}_{1}, \mathrm{P}_{2} \mathrm{Y}_{12}$, and $\mathrm{P}_{2} \mathrm{X}_{1}$ receptors (Hollopeter et al., 2001). "Mega" clinical trials CAPRIE (CAPRIE Steering Committee, 2001), CURE (Yusuf et al., 2001), and CREDO (Beinart et al., 2005) have provided clear evidence that the purinergic antithrombotic drugs clopidogrel and ticlopidine reduce the risks of recurrent strokes and heart attacks, especially when combined with aspirin (Kam and Nethery, 2003; Kunapuli et al., 


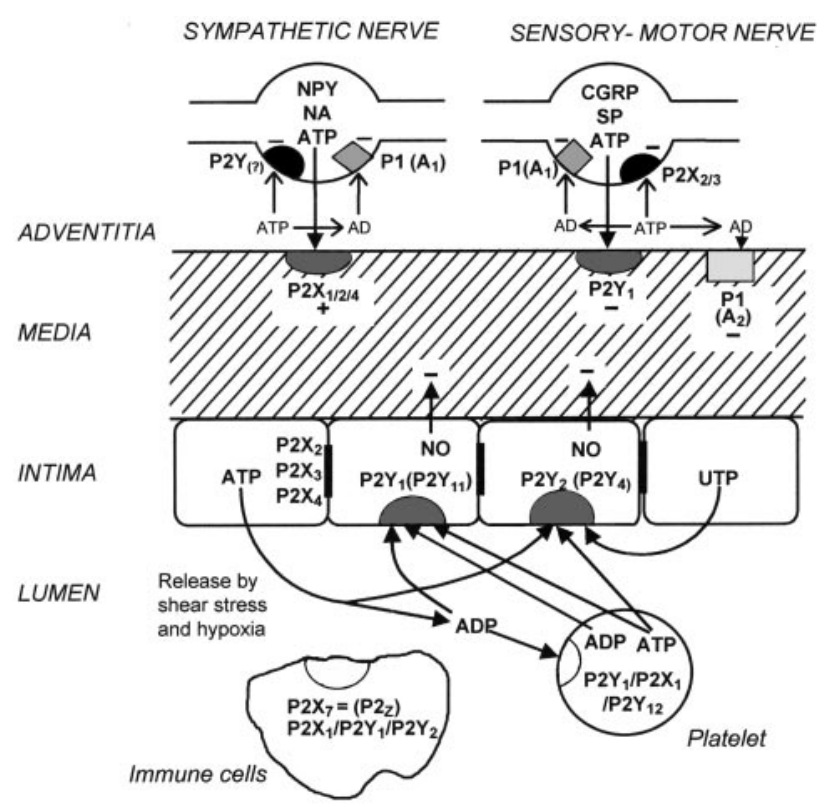

FIG. 1. Short-term (acute) purinergic signaling controlling vascular tone. Schematic diagram illustrating the main receptor subtypes for purine and pyrimidines present in most blood vessels. Perivascular nerves in the adventitia release ATP as a cotransmitter: ATP is released with NA and neuropeptide Y (NPY) from sympathetic nerves to act on smooth muscle $\mathrm{P} 2 \mathrm{X}_{1}$ and in some vessels $\mathrm{P} 2 \mathrm{X}_{2}, \mathrm{P}_{2} \mathrm{X}_{4}$, and $\mathrm{P}_{2} \mathrm{Y}_{2}$ purinoceptors, resulting in vasoconstriction; it is released with calcitonin generelated peptide (CGRP) and substance $\mathrm{P}(\mathrm{SP})$ from sensory nerves during "axon reflex" activity to act on smooth muscle P2Y-purinoceptors in some regions of some vessels, resulting in vasodilatation. $\mathrm{P} 1\left(\mathrm{~A}_{1}\right)$-purinoceptors on nerve terminals of sympathetic and sensory nerves mediate adenosine (arising from enzymatic breakdown of ATP) modulation of transmitter release. $\mathrm{P} 2 \mathrm{X}_{3}$ purinoceptors are present on a subpopulation of sensory nerve terminals. $\mathrm{P} 1\left(\mathrm{~A}_{2}\right)$-purinoceptors on vascular smooth muscle mediate vasodilatation. Endothelial cells release ATP and UTP during shear stress and hypoxia to act on $\mathrm{P}_{2} \mathrm{Y}_{1}, \mathrm{P}_{2} \mathrm{Y}_{2}$, and sometimes $\mathrm{P}_{2} \mathrm{Y}_{4}$ purinoceptors, leading to the production of $\mathrm{NO}$ and subsequent vasodilatation. ATP, following its release from aggregating platelets, also acts on these endothelial receptors. Blood-borne platelets possess $\mathrm{P}_{2} \mathrm{Y}_{1}$ and $\mathrm{P}_{2} \mathrm{Y}_{12}$ $\mathrm{ADP}$-selective purinoceptors as well as $\mathrm{P}_{2} \mathrm{X}_{1}$ receptors, whereas immune cells of various kinds possess $\mathrm{P}_{2} \mathrm{X}_{7}$, as well as $\mathrm{P} 2 \mathrm{X}_{1}, \mathrm{P}_{2} \mathrm{Y}_{1}$, and $\mathrm{P} 2 \mathrm{X}_{2}$ purinoceptors. $\mathrm{P} 2 \mathrm{X}_{2}, \mathrm{P} 2 \mathrm{X}_{3}$, and $\mathrm{P} 2 \mathrm{X}_{4}$ receptors have also been identified on endothelial cell membranes. Reproduced from Burnstock (2002a), with permission from Lippincott Williams \& Wilkins (Philadelphia, PA).

2003; Boeynaems et al., 2005). These drugs are antagonists to the $\mathrm{P}_{2} \mathrm{Y}_{12}$ receptor that mediates platelet aggregation (Gachet, 2001). MRS2500, a highly potent and selective antagonist for the $\mathrm{P}_{2} \mathrm{Y}_{1}$ receptor, has also been shown recently to have antiaggregating activity on human platelets (Cattaneo et al., 2004). There are genetic variations in $\mathrm{P}_{2} \mathrm{Y}_{1}$ and $\mathrm{P} 2 \mathrm{Y}_{12}$ receptor gene sequences in healthy subjects that explain variations in the platelet response to $\mathrm{ADP}$; this may reflect individual variation in atherothrombotic risk and the efficacy of purinergic antithrombotic drugs (Fontana et al., 2003; Hetherington et al., 2004). A recent study has shown that there is a synergistic inhibition of ADP-induced platelet activation via $\mathrm{P}_{2} \mathrm{Y}_{1}$ and $\mathrm{P}_{2} \mathrm{Y}_{12}$ receptors and for thrombin and $\mathrm{P}_{2} \mathrm{Y}_{12}$ inhibition; it is suggested that there may be clinical benefit by combining these inhibitors, providing that bleeding problems do not outweigh this benefit $(\mathrm{Ny}-$ lander et al., 2004). Postoperative carotid thrombosis is a significant risk for stroke; it seems likely that clopi- dogrel or ticlopidine may provide an avenue for targeted antiplatelet therapy following vascular intervention (Hayes et al., 2003). Platelet aggregation in response to ADP is significantly inhibited in patients with peripheral vascular disease 2 to $4 \mathrm{~h}$ after a loading dose of clopidogrel, and ADP-induced platelet shape change is significantly inhibited following ingestion of clopidogrel (Matsagas et al., 2003). There is a synergistic interaction between ATP and noradrenaline in stimulating platelet aggregation, which suggests a prothrombotic role for ATP in stress (Birk et al., 2003). Platelet activation that occurs in human acute malaria infection is associated with elevated plasma ATP concentrations (Essien and White, 1998).

Much is now known about the ectonucleotidases that break down ATP released from non-neural cells as well as neurons (Zimmermann, 2001; Vorhoff et al., 2005). Several enzyme families are involved: ectonucleoside triphosphate diphosphohydrolases (E-NTPDases), of which NTPDase1, 2, 3, and 8 are extracellular; ectonucleotide pyrophosphatase of three subtypes; alkaline phosphatases, ecto-5'-nucleotidase and ectonucleoside diphosphokinase. NTPDase1 hydrolyzes ATP directly to AMP and UTP to UDP, whereas NTPDase2 hydrolyzes ATP to ADP and 5'-nucleotidase AMP to adenosine. Ectonucleotidases are expressed by vascular endothelium, accessory vascular cells (e.g., monocytes, pericytes, and vascular smooth muscle cells), and dendritic cells; these are predominantly NTPDase1 and NTPDase2 (Sevigny et al., 2002). NTPDase1 hydrolyzes both triand diphosphonucleosides and blocks platelet aggregation responses to ADP. In contrast, NTPDase2, a preferential nucleoside triphosphatase, activates platelets by converting the competitive antagonist (ATP) of platelet ADP receptors to the specific agonist. Vascular NTPDase1 biochemical activity is rapidly lost from the endothelium of vascularized cardiac grafts subjected to oxidant stress. These changes are associated with thrombotic injury and platelet sequestration at sites of injury.

\section{B. Heart Failure}

Up-regulation of $\mathrm{P} 2 \mathrm{X}_{1}$ and $\mathrm{P}_{2} \mathrm{Y}_{2}$ receptor mRNA in the hearts of rats with congestive heart failure has been reported (Hou et al., 1999) and an increase in expression of $\mathrm{P}_{2} \mathrm{X}_{1}$ receptors in the atria of patients suffering from dilated cardiomyopathy (Berry et al., 1999). In congestive heat failure, the muscle mechanoreflex is accentuated and appears to be associated with enhanced P2X receptor-mediated responses of sensory nerves to $\alpha, \beta$ methylene ATP (Sinoway and Li, 2005). The positive inotropic response to ATP and ATP-induced increases in $\left[\mathrm{Ca}^{2+}\right]_{\mathrm{i}}$ in cardiomyocytes are impaired in heart failure due to myocardial infarction; imidapril partially reverses this impairment (Saini et al., 2005). ATP and adenosine are widely used for the treatment of paroxysmal supraventricular tachycardia in both infants and 
adults (Belhassen and Pelleg, 1985; Vassort, 2001). The substantial enhancement of mechanical performance with 2-deoxy-ATP in cardiac muscle suggests that it may be a better substrate for contractility than ATP and suggests that ribonucleotide reductase may be a target for therapy in heart failure (Regnier et al., 2000).

Enhanced sympathetic nerve activity causes cardiac dysfunction, arrhythmias, and sudden cardiac death in myocardial ischemia. ATP is coreleased with noradrenaline (NA) and enhances NA release from sympathetic nerve terminals. A role for the ectonucleotidase, E-NTPDase1 at sympathetic nerve terminals may offer a novel therapeutic approach to hyperadrenergic states such as myocardial ischemia (Sesti et al., 2002). Because NTPDase1 also inhibits platelet aggregation, it is proposed for the treatment of thrombotic diatheses (Marcus et al., 2003). To examine the role of NTPDases after cardiac transplantation and grafts, several techniques to manipulate NTPDase1 expression have been used, for example, deletion of this enzyme in mice. These mutant mice exhibit major perturbations of $\mathrm{P} 2$ receptor-mediated signaling in the vasculature and immune systems and show hemostatic defects, thromboregulatory disturbances, and heightened acute inflammatory responses with a failure to generate cellular responses (Enjyoji et al., 1999); NTPDase1-null hearts have been shown to develop diffuse thrombotic infarcts and undergo rejection more rapidly than control grafts when transplanted into wild-type mice or into rats. In contrast, transgenic organs or cardiac grafts in which NTPDase1 has been up-regulated by gene therapy vectors enjoy a survival advantage post-transplantation (Imai et al., 2000).

ATP is routinely used to terminate spontaneous ventricular tachycardia, but it is not always successful, although no difference in efficacy was found between ischemic and nonischemic cardiomyopathy (Kouakam et al., 2003). By using transgenic overexpression of human $\mathrm{P}_{2} \mathrm{X}_{4}$ receptors, cardiac $\mathrm{P} 2 \mathrm{X}_{4}$ receptors have been shown to have a beneficial life-prolonging role in heart failure; increased expression or activation of these ATP-stimulated receptor channels may represent a new therapeutic approach to the treatment of heart failure (Yang et al., 2004). Administration of ATP during sinus rhythm has been suggested as a useful bedside test for identifying patients with a concealed accessory pathway who are prone to develop atrioventricular reentrant tachycardia (Belhassen et al., 2000). The negative chronotropic effect of ATP on sinus node is much more pronounced in patients with sick sinus syndrome (Tan et al., 2004).

Magnesium-ATP has been recommended for the treatment of ischemia, radiation injury, shock, and sepsis for many years (Harkema and Chaudry, 1992; Nalos et al., 2003). A recent study suggests that the protective effect of ATP on renal ischemic injury is, in part, related to inhibition of the inducible transcription factor, nuclear factor- $\kappa \beta$, via P2Y receptors in proximal tubule cells (Lee and Han, 2005). ATP was shown to inhibit atrio- ventricular conduction rather than the firing rate of sinoatrial nodes in patients with ischemic heart disease; injection of ATP is used only when a transient cardiac standstill is needed, such as for endovascular grafting surgery (Watanabe et al., 2002). Treatment of myocardial ischemia and reperfusion by ATP- $\mathrm{MgCl}_{2}$ is still recommended (Katircioglu et al., 2000), but many reports suggest that adenosine (a breakdown product of ATP) also mediates this effect (Liang and Jacobson, 1999; Broadley, 2000; Sommerschild and Kirkeboen, 2000; Thompson et al., 2002).

\section{Hypertension}

ATP plays a significant cotransmitter role in sympathetic nerves supplying hypertensive blood vessels. The purinergic component is increased in spontaneously hypertensive rats (Ralevic and Burnstock, 1998). The increase in sympathetic nerve activity in hypertension is well established, and there is an associated hyperplasia and hypertrophy of arterial walls (Julius and Nesbitt, 1996). ATP is a rapidly acting hypotensive agent that compares favorably with sodium nitroprusside (Kien et al., 1987). ATP- $\mathrm{MgCl}_{2}$ is a safe, effective, and preferential pulmonary vasodilator in children with pulmonary hypertension secondary to congenital heart defects; it has also been used for treating pulmonary hypertension after cardiac surgery (Brook et al., 1994). Red blood cells of humans with primary pulmonary hypertension fail to release ATP in response to mechanical deformation (Sprague et al., 2001). This is likely to result in the loss of local control of total pulmonary vascular resistance in the lung. Low-dose ATP exerts mitogenic actions on human pulmonary artery smooth muscle cells, which may be relevant to the pathophysiological basis of severe pulmonary hypertension (Zhang et al., 2004b). Pulmonary hypertension can be a problem in patients with chronic obstructive pulmonary disease, which also has other causes; it is a life-threatening condition, and intravenous ATP infusion produces a significant decrease in mean pulmonary arterial pressure and pulmonary vascular resistance without changing the mean systemic arterial pressure (Brook et al., 1994). ATP has been used to treat meconium aspiration-induced pulmonary hypertension in pigs (Kääpä et al., 1997). Eicosapentaenoic acid, one of the active components in fish oil that has antihypertensive effects, increases the release of ATP from vascular endothelial cells, leading to reduction of the blood pressure rise characteristic of aging (Hashimoto et al., 1998). It has been proposed that there is prognostic value of stress myocardial perfusion imaging using ATP at the beginning of hemodialysis treatment in patients with end-stage renal disease (Hase et al., 2004). $\mathrm{P}_{2} \mathrm{X}_{4}$ receptors are localized in the syncytiotrophoblast, stroma, and fetal capillary endothelial cells of human placenta. Placental P2X $\mathrm{X}_{4}$ receptors are significantly upregulated in mild preeclampsia (Roberts et al., 2005). The authors hypothesized that with preeclampsia, in 
which there is an increased potential for ATP release, $\mathrm{P}_{2} \mathrm{X}_{4}$ receptors may mediate a change in cellular homeostasis to limit cell damage.

\section{Atherosclerosis and Restenosis}

An early study reported that adenosine produces changes in cAMP and DNA synthesis in cultured arterial smooth muscle cells and suggested that this might result in the regulation of cell proliferation (Jonzon et al., 1985). The authors speculated that adenosine could be one of several regulatory factors in the development of atherosclerosis and might also regulate the release of a smooth muscle mitogen, platelet-derived growth factor. There is now good evidence that adenosine does regulate smooth muscle cell proliferation, but its properties differ from those for ATP and ADP (Burnstock, 2002a; Di Virgilio and Solini, 2002). Vascular injury represents a critical initiating event in the pathogenesis of various vascular diseases. Large amounts of ATP are released from injured cells and ATP and adenosine have potent actions in smooth muscle and endothelial cell growth, migration, proliferation, and death (Burnstock, 2002a). Apoptotic cell death is recognized to occur in a number of vascular diseases, including atherosclerosis and restenosis. Vascular endothelial cells are continuously exposed to variations in blood flow, which plays an important role in vessel growth or regression and in the local development of atherosclerosis. The shear stress that occurs during changes in blood flow leads to substantial release of ATP (and UTP) from endothelial cells (Burnstock, 1999), and these purines might mediate alterations in the balance between proliferation and apoptosis. Atherosclerotic damage results in the disappearance of endothelium-dependent responses to ATP. The release of ATP from endothelial cells has also been claimed to be impaired in atherosclerotic arteries and long-term supplementation with a high cholesterol diet decreases the release of ATP. In restenosis following balloon angioplasty, there is a peak in the proliferation and apoptosis of vascular smooth muscle cells at approximately 14 days. Clinical trials with clopidogrel and ticlopidine $\left(\mathrm{P} 2 \mathrm{Y}_{12}\right.$ receptor antagonists) in patients with atherosclerotic disease have shown significant benefit compared with aspirin.

Saphenous vein, internal mammary, and radial arteries have been used as grafts for coronary bypass surgery; the level of endothelial $\mathrm{P}_{2} \mathrm{Y}_{2}$ receptors is comparable in all three vessels, but endothelial $\mathrm{P}_{2} \mathrm{X}_{4}$ receptors vary from high in saphenous vein to significantly lower in the other two vessels. It has been suggested that P2X $\mathrm{X}_{4}$ receptors play a more significant role in intense proliferation in arteriosclerosis and restenosis than $\mathrm{P}_{2} \mathrm{Y}_{2}$ receptors, as reflected by the susceptibility of saphenous vein grafts to atherosclerosis compared with internal mammary arteries (Ray et al., 2002). In another study, $\mathrm{P}_{2} \mathrm{X}_{1}$ and $\mathrm{P}_{2} \mathrm{Y}_{6}$ receptors mediated more prominent contractions in the saphenous vein compared with the internal mammary artery; it has been suggested that selective antagonists to these receptors may prevent vasospasm and restenosis in the saphenous vein during and after revascularization surgery (Borna et al., 2003). A novel role for $\mathrm{P}_{2} \mathrm{Y}_{2}$ receptors in the development of atherosclerosis has been suggested, whereby UTP induces vascular cell adhesion molecule- 1 expression in coronary artery endothelial cells that mediate the recruitment of monocytes (Seye et al., 2003). The long-term (trophic) roles of purinergic signaling in vascular smooth muscle and endothelial cell proliferation and death have been implicated in atherosclerosis and restenosis and suggest the exploration of therapeutic strategies in relation to these events (Erlinge et al., 1998; Burnstock, 2002b; Hou et al., 2002; Wang et al., 2003b).

Newly developing vascular endothelia express very high levels of NTPDase1, also seen under hypoxic conditions (Eltzschig et al., 2003). Angiogenesis requires the dynamic interaction of endothelial cell proliferation and differentiation with orchestrated interactions between extracellular matrix and surrounding cells (such as vascular smooth muscle and/or pericytes). Such interactions could be coordinated by interplay between nucleotide release, P2 receptor modulation, and altered NTPDase expression (Goepfert et al., 2001). The role for adenosine in growth regulation in angiogenesis has been reviewed recently (Adair, 2005).

Varicose veins are characterized by hypoxia, inflammation, and cell death, all likely to lead to increases in extracellular ATP. $\mathrm{P}_{2} \mathrm{X}_{1}$ and $\mathrm{P}_{2} \mathrm{X}_{7}$ receptors are expressed by saphenous vein smooth muscle, and it has been suggested that the resultant $\mathrm{P} 2 \mathrm{X}_{7}$ receptor activation contributes to the decrease in contractile myocytes and resulting disorganization of the vessel wall (CarioToumaniantz et al., 1998).

\section{Neurology}

Functional implications for purinergic signaling in the nervous system include neuron-glia interactions, differentiation of stem cells, diseases of the nervous system and responses to injury, neuroimmune and neurovascular interactions, sympathetic transmission and plasticity, glial cell differentiation, intercellular communication between glia, and myelination (Fields and Stevens, 2000; Burnstock, 2003b; Newman, 2003; Pascual and Haydon, 2003; Bowser and Khakh, 2004; Mulligan and MacVicar, 2004; Davalos et al., 2005; Köles et al., 2005).

ATP is a cotransmitter in many nerve types, probably reflecting the early evolutionary presence of purinergic signaling (Burnstock, 1996a, 2004). There is evidence for the action of ATP as a cotransmitter with NA and neuropeptide $\mathrm{Y}$ in sympathetic nerves, with acetylcholine and vasoactive intestinal peptide in some parasympathetic nerves, with $\mathrm{NO}$ and vasoactive intestinal peptide in enteric NANC inhibitory nerves, and with calcitonin gene-related peptide (CGRP) and substance P in senso- 
ry-motor nerves. There is also evidence for the cotransmission of ATP with GABA in retinal nerves, and with glutamate, 5-hydroxytryptamine (serotonin), NA, or dopamine in nerves in the brain (Burnstock, 2003b). In sympathetically innervated tissues, such as the vas deferens or blood vessels, ATP produces fast responses mediated by P2X receptors, followed by a slower component mediated by $\mathrm{G}$ protein-coupled $\alpha$-adrenoceptors. Similarly, in the parasympathetic nerves supplying the urinary bladder, ATP provokes a fast transient response via P2X receptors, whereas the slower component is mediated by $\mathrm{G}$ protein-coupled muscarinic receptors. There are differences in the proportion of cotransmitters between species in development and aging and in different pathophysiological conditions. $\mathrm{P}_{2} \mathrm{X}_{3}$ and $\mathrm{P} 2 \mathrm{X}_{2 / 3}$ receptors are selectively localized on sensory neurons in trigeminal, nodose, and dorsal root ganglia (DRG), and the terminals of these nociceptive neurons in the skin and visceral organs represent unique targets for novel analgesic agents that function as $\mathrm{P}_{2} \mathrm{X}_{3}$ and $\mathrm{P}_{2} \mathrm{X}_{2 / 3}$ receptor antagonists. Nonspecific P2 receptor antagonists, e.g., suramin and pyridoxal-5'-phosphate-6-azophenyl$2^{\prime}, 4^{\prime}$ disulfonic acid (PPADS), are antinociceptive, and $\mathrm{P}_{2} \mathrm{X}_{3}$ receptor-knockout mice reduce nociceptive inflammatory responses (Cockayne et al., 2000; Burnstock, 2001b).

The first clear evidence for nerve-nerve purinergic synaptic transmission was published in 1992 (Edwards et al., 1992; Evans et al., 1992; Silinsky et al., 1992). Synaptic potentials in the celiac ganglion and in the medial habenula in the brain were reversibly antagonized by suramin. Since then, many articles have described either the distribution of various P2 receptor subtypes in the brain and spinal cord or electrophysiological studies of the effects of purines in brain slices, isolated nerves, and glial cells (Burnstock, 2003b). Synaptic transmission has also been demonstrated in the myenteric plexus and in various sensory, sympathetic, and pelvic ganglia (Dunn et al., 2001). Adenosine, produced following ectoenzymatic breakdown of ATP, acts through presynaptic $\mathrm{P} 1$ receptors to inhibit the release of excitatory neurotransmitters in both the peripheral and the central nervous systems. P2Y receptors are expressed on both nonmyelinating and myelinating Schwann cells.

\section{A. Neuroprotection}

In the brain, $\mathrm{P} 2$ purinergic signaling is involved in the regulation of a variety of physiological and pathophysiological processes, including development and nervous tissue remodeling following trauma, stroke, ischemia, or neurodegenerative disorders (Burnstock, 2003a; Neary et al., 2004). Agonists and antagonists of adenosine and inhibitors of adenosine kinase are also being explored as therapeutic neuroprotective agents as well as for a number of other neurological conditions including epilepsy, sleep apnoea, pain, inflammation, aggression, anxiety, and memory loss (Kowaluk and Jarvis, 2000; Ribeiro et al., 2003; Fredholm et al., 2005; Köles et al., 2005). Microinjection of ATP analogs into the prepiriform cortex induces generalized motor seizures (Knutsen and Murray, 1997). $\mathrm{P} 2 \mathrm{X}_{2}, \mathrm{P}_{2} \mathrm{X}_{4}$, and $\mathrm{P} 2 \mathrm{X}_{6}$ receptors are expressed in the prepiriform cortex, suggesting that $\mathrm{P} 2 \mathrm{X}$ receptor antagonists may have potential as neuroleptic agents. The hippocampus of chronic epileptic rats shows abnormal responses to ATP associated with increased expression of $\mathrm{P} 2 \mathrm{X}_{7}$ receptors; it has been suggested that $\mathrm{P} 2 \mathrm{X}_{7}$ receptors (perhaps on microglia) may participate in the pathophysiology of temporal lobe epilepsy (Vianna et al., 2002).

In nervous tissue, trophic factors ensure neuronal viability and regeneration. Neuronal injury releases fibroblast growth factor, epidermal growth factor, and platelet-derived growth factor (Neary et al., 1999). In combination with these growth factors, ATP can stimulate astrocyte proliferation, contributing to the process of reactive astrogliosis, and to hypertrophic/hyperplastic responses. P2Y receptor antagonists have been proposed as potential neuroprotective agents in the cortex, hippocampus, and cerebellum by modulation of kainate and $\alpha$-amino-3-hydroxy-5-methyl-4-isoxazolepropionic acidinduced currents, excessive activation of glutamate receptor systems being implicated in neuronal cell death associated with stroke, epileptic seizures, and neurodegenerative diseases such as Alzheimer's, Parkinson's, Huntington's, and amyotrophic lateral scoliosis (Zona et al., 2000). Release of ATP from disrupted cells may cause cell death in neighboring cells expressing $\mathrm{P}_{2} \mathrm{X}_{7}$ receptors, leading to a necrotic volume increase, which has been proposed as a cellular mechanism in the pathogenesis of Parkinson's disease (Jun and Kim, 2004). Guanine nucleotides inhibit NMDA and kainate-induced neurotoxicity in cultured rat hippocampal and neocortical neurons and may be candidates for antagonizing glutamate receptor-mediated neurotoxicity (Morciano et al., 2004). P2 receptors have been claimed to mediate neuroprotective effects in the cerebellum and the possible therapeutic use of $\mathrm{P} 2$ receptor agonists as neuroprotective agents has been raised (Volonte et al., 1999, 2003). It has been suggested that adenine is involved in the control of Purkinje cell survival (Watanabe et al., 2003). Up-regulation of $\mathrm{P} 2 \mathrm{X}_{1}$ and $\mathrm{P} 2 \mathrm{X}_{2}$ receptors after cerebellar lesions has been reported (Florenzano et al., 2002). Purine derivatives are in clinical trials as memory-enhancing agents in Alzheimer's disease; two of these, propentofylline and AIT-082, appear to act as trophic effectors, increasing the production of neurotrophic factors in brain and spinal cord (Rathbone et al., 1999). It has been reported that aluminum can produce Alzheimer-like symptoms, and a mechanism has been proposed whereby the aluminum binds to ATP to act on P2 purinoceptors leading to formation of amyloid fibrils (Exley and Korchazhkina, 2001). The therapeutic potential of adenosine $\mathrm{A}_{2 \mathrm{~A}}$ receptor antagonists in Parkinson's 
disease is being explored (Simola et al., 2004; Xu et al., 2005).

ATP inhibits the release of the excitatory transmitter, glutamate, and stimulates release of the inhibitory transmitter, GABA, from hippocampal nerves, thus serving a protective role (Inoue, 1998). In addition, ATP coreleased with glutamate induces long-term potentiation (LTP) in CA1 neurons associated with learning and memory (Fujii et al., 1999; Mori et al., 2001). Nanomolar concentrations of ATP induce long-lasting enhancement of LTP in hippocampal neurons; the P2 antagonist, suramin, inhibited activity of the ectoenzyme, apyrase, which has been shown to participate in the mechanisms of memory acquisition (Bonan et al., 1999). It has been suggested that ATP coreleased with glutamate activates CA1 pyramidal hippocampal neurons, allowing calcium to enter postsynaptic cells and thereby inhibiting the effectiveness of NMDA receptors in inducing LTP (Pankratov et al., 2002). Because P2X receptors contribute to synaptic transmission, mainly at low frequencies of stimulation, they may act as a dynamic low-frequency filter, preventing weak stimuli from inducing long-lasting changes in synaptic efficacy. It has also been claimed that ATP analogs can facilitate LTP through P2 receptor activation that triggers adenosine release, leading to activation of $\mathrm{P} 1\left(\mathrm{~A}_{2 \mathrm{~A}}\right)$ receptors (Almeida et al., 2003). Large rises in $\left[\mathrm{Ca}^{2+}\right]_{\mathrm{i}}$ in CA1 neurons induce LTP, but small rises induce long-term depression (Yamazaki et al., 2002). ATP and activation of glutamate NMDA receptors leads to potentiation of LTP in CA1 neurons (Fujii et al., 2002) in keeping with the synergism that often occurs between cotransmitters (Burnstock, 2004). There is expression of functional P2X receptor channels in the axons of CA3 neurons branching to their postsynaptic targets and predominantly in nerve terminals forming synapses with interneurons (Khakh et al., 2003).

ATP, released from astrocytes, acts as an activitydependent signaling molecule in neuron-glia communication, resulting in astrocyte $\mathrm{Ca}^{2+}$ waves and synaptic modulation; neuron-glia cross talk may represent an integral part of activity-dependent plasticity of neural networks (Zhang et al., 2003). Clearly there are multiple roles for $\mathrm{P} 2$ and $\mathrm{P} 1$ receptors in relation to learning and memory, but the way that therapeutic manipulation of purinergic mechanisms can be used to improve these functions is still unresolved. Higher order cognitive functions, including learning and memory in the prefrontal cortex appear to involve P2Y receptor signaling (Wirkner et al., 2003).

ATP injected into the supraoptic nucleus of the hypothalamus has antidiuretic effects (Mori et al., 1994). Purinergic and adrenergic synergism for vasopressin and oxytocin release is consistent with ATP cotransmission in the hypothalamus (Kapoor and Sladek, 2000). Purinergic signaling appears to play a significant role in the regulation of body temperature during fever by cen- tral hypothalamic and brainstem nuclei (Gourine et al., 2002, 2004). Functional interactions seem likely to occur between purinergic and nitrergic neurotransmitter systems; they may be important for regulation of hormone secretion and body temperature at the hypothalamic level and for cardiovascular and respiratory control at the level of the brainstem (Yao et al., 2003). ATP is coreleased with GABA or NA to act on P2 receptors, which are strongly expressed in most nuclei in the hypothalamus, including arcuate, paraventricular, retrochiasmatic, supraoptic, ventromedial, and dorsomedial (Matsumoto et al., 2004).

$\mathrm{P} 2 \mathrm{X}$ and $\mathrm{GABA}_{\mathrm{A}}$ receptors play an important role in $\mathrm{CO}_{2}$ chemoreception and are involved in mediation of the ventilatory response to hypercapnia (Gourine and Spyer, 2003). P2X receptors expressed in neurons in the trigeminal mesencephalic nucleus may be involved in the processing of proprioceptive information (Khakh et al., 1997). The nucleus tractus solitarius (NTS) is a major integrative center in the brainstem that is involved in reflex control of the cardiovascular system; stimulation of P2X receptors in the NTS evokes hypotension with decreases in both cardiac output and total peripheral resistance (Kitchen et al., 2001). Different NTS purinoceptor subtypes may contribute to patterned autonomic responses observed in specific physiological or pathological situations (Scislo et al., 2001). Evaluation of the roles of purinergic signaling in processing of the sympathoexcitatory component of the chemoreflex at the NTS level may illuminate the mechanisms underlying the sympathetic overactivity observed in pathophysiological conditions such as hypertension, obstructive sleep apnea, and heart failure (De Paula et al., 2004).

In the striatum, extracellular ATP and adenosine are involved in the regulation of the feeding-associated mesolimbic neuronal activity in an antagonistic manner (Kittner et al., 2003). PPADS suppresses the feedingevoked dopamine release in the nucleus accumbens, a brain region regarded as important for the regulation of appetite behavior and reinforcement (Kittner et al., 2000). Adenosine-dopamine interactions in the ventral striatum have been implicated in schizophrenia (Tsai, 2005). A hypothesis in which dysfunction of purinergic signaling (for example, decreased ATPase activity in erythrocytes, leading to increased levels of ATP and decreased adenosine) may lead to schizophrenia has been put forward (Lara and Souza, 2000).

It has been claimed that purinergic signaling dysfunction (perhaps largely reduced adenosinergic activity) is involved in mania and aggressive behavior (MachadoVieira et al., 2002). Endogenous ATP has been claimed to be involved in the regulation of anxiety via stimulation of $\mathrm{P}_{2} \mathrm{Y}_{1}$ receptors in the dorsomedial hypothalamus in rats (Kittner et al., 2003). Chronically administered guanosine has anticonvulsant, amnesic, and anxiolytic effects in mice, perhaps associated with modulation of glutamatergic excitation (Vinade et al., 2003). 
Multiple P2X and P2Y receptors have been identified on single cerebellar granule cells (Hervas et al., 2003). It has been reported that ATP continuously modulates the cerebellar circuit by increasing the inhibitory input to Purkinje neurons, probably via $\mathrm{P}_{2} \mathrm{X}_{5}$ and $\mathrm{P}_{2} \mathrm{Y}_{2}$ and/or $\mathrm{P}_{2} \mathrm{Y}_{4}$ receptor subtypes, thus decreasing the main cerebellar output activity, which contributes to locomotor coordination (Brockhaus et al., 2004).

Spinal cord traumas are a major health problem. ATP$\mathrm{MgCl}_{2}$ has been shown to decrease lipid peroxidation in spinal cord injury and protect the spinal cord from secondary injury after trauma; it was concluded that ATP$\mathrm{MgCl}_{2}$ should be explored for the treatment of spinal cord injuries in conjunction with other treatment modulators (Cakir et al., 2003). In a recent study, topical application of ATP after spinal cord injury significantly improved locomotor function (Shields et al., 2004).

Phenylketonuria is an innervated deficiency of phenylalanine hydroxylase activity in the liver, which causes increased brain levels of phenylalanine and its metabolites, leading to permanent brain damage in the early period of postnatal brain development. Phenylalanine has been shown to inhibit ATP diphosphohydrolase, resulting in increases in ATP levels, perhaps the neurotoxic mechanism underlying brain damage in this disease (Berti et al., 2001).

Acanthamoeba is a protozoan parasite that can cause fatal granulomatous amebic encephalitis. It has been shown recently to hydrolyze ATP, and it was suggested that this ecto-ATPase activity may play a role in the pathogenesis of this disease (Sissons et al., 2004).

Diadenosine tetraphosphate $\left(\mathrm{Ap}_{4} \mathrm{~A}\right)$ protects against injuries induced by ischemia and 6-hydroxytryptamine in rat brain and has been suggested as a potentially useful target molecule in the therapy of stroke (Wang et al., 2003b). Up-regulation of $\mathrm{P} 2 \mathrm{X}_{2}$ and $\mathrm{P} 2 \mathrm{X}_{4}$ receptors in organotypic cultures of hippocampus, cortex, and striatum is associated with ischemic cell death and was prevented by P2 receptor antagonists (Cavaliere et al., 2003).

ATP is an extracellular signaling molecule between neurons and glial cells. ATP released by cellular damage and from astrocytes may be important in triggering cellular responses to trauma and ischemia by initiating and maintaining reactive astrogliosis, which involves striking changes in proliferation and morphology of astrocytes and microglia. Some of the responses to ATP released during brain injury are neuroprotective, but in some cases ATP contributes to the pathophysiology initiated after trauma (Fields and Stevens-Graham, 2002; Murakami et al., 2003; Neary et al., 2003; Meme et al., 2004). It has been claimed that $\mathrm{P}_{2} \mathrm{Y}_{2}$ receptors activate neuroprotective mechanisms in astrocytic cells (Chorna et al., 2004). In contrast, experimental infusion of ATP into nucleus accumbens or cerebral hemisphere of rats suggests that purines might be a signal for induction of malignant brain tumors. It has been claimed recently that ischemic brain injury is regulated by extracellular
ATP-mediated interleukin (IL)-10 expression in microglia (Han et al., 2004). Multiple P2X and P2Y receptor subtypes are expressed by astrocytes, oligodendrocytes, and microglia (James and Butt, 2002). P2Y receptors mediate reactive astrogliosis via induction of COX-2, and $\mathrm{P} 2 \mathrm{Y}$ receptor antagonists might counteract excessive COX-2 activation in both acute and chronic neurological disease (Brambilla et al., 1999). P2 receptors also mediate regulation of COX-2 in microglia (Choi et al., 2003). IL-1 $\beta$-induced astrocyte activation is regulated by purinergic signaling; this is compatible with the hypothesis that nucleotides released under inflammatory conditions activate autocrine or paracrine signaling pathways that modulate inflammation (John et al., 2001).

Recent experiments suggest that astrocytes can sense the severity of damage in the central nervous system (CNS) via ATP release from damaged cells and can modulate the tumor necrosis factor- $\alpha$-mediated inflammatory response, depending on the extracellular ATP concentration and corresponding type of astrocyte P2 receptor activated (Kucher and Neary, 2005). Thus, micromolar ATP/ $\mathrm{P} 2 \mathrm{Y}$ receptor activation may act to boost a moderate inflammatory response, whereas millimolar ATP/P2X receptor activation may prevent the perpetuation of a comparatively large inflammatory response perhaps by induction of apoptosis. Protein kinase B/Akt is a key signaling molecule that regulates cell survival, growth and metabolism and inhibits apoptosis. Traumatic brain injury activates Akt. When cortical astrocytes were subjected to mechanical strain, ATP was released, leading to Akt activation; PPADS attenuated the Akt activation (Neary et al., 2005). ATP can activate $P 2 X_{7}$ receptors in astrocytes to release glutamate, GABA, and ATP, which regulate the excitability of neurons (Wang et al., 2002). ATP release during neuronal excitation or injury can enhance the inflammatory effects of cytokines and prostaglandin $\mathrm{E}_{2}$ in astrocytes and may contribute to the chronic inflammation seen in Alzheimer's disease (Xu et al., 2003). Astrocytic gap junctions are involved in the neuroprotective process, in particular, to protect neurons from oxidative stress and glutamate toxicity (Naus et al., 2001). ATP released from astrocytes is essential in mediating the injury-induced responses of microglial processes (Davalos et al., 2005).

Microglial cells are the major cellular elements with immune functions inside the CNS and play important roles in orchestrating inflammatory brain responses to trauma and hypoxia. They express multiple P2 receptors (Bianco et al., 2005) and are activated by purines and pyrimidines to release inflammatory cytokines such as IL- $1 \beta$ and IL- 6 and tumor necrosis factor- $\alpha$. Activated microglia can also act as scavenger cells that induce apoptosis in damaged neurons by releasing toxic factors, including NO (Sanz and Di Virgilio, 2000; Inoue, 2002). Thus, whereas microglia may play an important role against infection in the CNS, overstimulation of this immune reaction may accelerate the neuronal damage caused by ischemia, trauma, or neurodegenerative dis- 
eases such as Alzheimer's and Parkinson's disease, human immunodeficiency virus encephalopathy, multiple sclerosis, and amyotrophic lateral scoliosis, which exhibit microglial proliferation and activation (Ogata et al., 2003). These authors showed that ATP inhibits cytokine release from lipopolysaccharide-activated microglia via $\mathrm{P} 2 \mathrm{Y}$ receptors and suggested that $\mathrm{P} 2 \mathrm{Y}$ agonists may be a potential treatment for toxic immunoreactions. $\mathrm{P}_{2} \mathrm{X}_{4}$ receptors, induced in spinal microglia, gate tactile allodynia after nerve injury (Tsuda et al., 2003) (see section II.B.). $\mathrm{P}^{2} \mathrm{X}_{7}$ receptors mediate superoxide production in primary microglia and are up-regulated in a transgenic model of Alzheimer's' disease, particularly around $\beta$-amyloid plaques (Parvathenani et al., 2003). Stimulation of microglial $\mathrm{P}_{2} \mathrm{X}_{7}$ receptors also leads to enhancement of interferon- $\gamma$-induced type II nitric oxide synthase activity (Gendron et al., 2003). P2X $\mathrm{X}_{7}$ receptors may therefore provide a therapeutic target for inflammatory responses seen in neurodegenerative disorders.

$\mathrm{P} 2$ receptors are expressed by oligodendrocytes. However, P2 receptors on oligodendrocytic progenitor cells mediate an increase in $\left[\mathrm{Ca}^{2+}\right]_{i}$ and may mediate the formation of myelin, raising the possibility that activation of $\mathrm{P} 2$ receptors may offer new approaches to the treatment of demyelinating diseases in the CNS, such as multiple sclerosis (Stevens et al., 2002; Agresti et al., 2005). P2X receptors expressed by Schwann cells may regulate the synthesis and release of cytokines during pathophysiological events (Colomar and Amedee, 2001; Irnich et al., 2001).

\section{B. Migraine}

Classical migraine is associated with two distinct cerebrovascular phases: an initial vasoconstriction (not associated with pain) followed by vasodilatation (reactive hyperemia) associated with pain. The "purinergic" hypothesis for migraine was originally put forward in 1981 as a basis for the reactive hyperaemia and pain during the headache phase (Burnstock, 1981). It was suggested that ATP and its breakdown products adenosine 5'-monophosphate and adenosine were strong contenders for mediating the vasodilatation following the initial vasospasm and subsequent hypoxia. ATP was also implicated in the pathogenesis of pain during migraine via stimulation of primary afferent nerve terminals located in the cerebral microvasculature. Later studies have shown that the ATP-induced cerebral vasodilatation is endothelium-dependent via activation of P2Y receptors on the endothelial cell surface and subsequent release of endothelium-derived relaxing factor and that the endothelial cells are the main local source of ATP involved, although adenosine 5' -diphosphate and ATP released from aggregating platelets may also contribute to this vasodilatation. These findings have extended the purinergic hypothesis for migraine in two ways. First, they have clarified the mechanism of purinergic vasodilatation during the headache phase of mi- graine. Second, they suggest that a purinergic mechanism may also be involved in the initial local vasospasm, via P2X receptors on smooth muscle cells occupied by ATP released either as a cotransmitter with NA from perivascular sympathetic nerves or from damaged endothelial cells (Burnstock, 1989). The hypothesis has gained further support by the identification of $\mathrm{P}_{2} \mathrm{X}_{3}$ receptors on primary afferent nerve terminals arising from trigeminal, nodose, and spinal ganglia (Chen et al., 1995; Burnstock, 2001b). Thus, $\mathrm{P}_{2} \mathrm{X}_{3}$ receptor antagonists may be candidates for antimigraine drug development (Waeber and Moskowitz, 2003). There is also recent evidence that migraine is a chronic sympathetic nervous system disorder, with which there is an increase in release of sympathetic cotransmitters, including ATP (Peroutka, 2004), which may contribute to the initial vasospasm (Macdonald, 2000).

\section{Pain}

The involvement of ATP in the initiation of pain was recognized early (Collier et al., 1966; Bleehen and Keele, 1977; Burnstock, 1981; Jahr and Jessell, 1983). A major advance was made when the $\mathrm{P}_{2} \mathrm{X}_{3}$ ionotropic receptor was cloned in 1995 (Chen et al., 1995; Lewis et al., 1995) and shown later to be predominantly localized in the subpopulation of small nociceptive sensory nerves that label with isolectin B4 (IB4) in DRG (Bradbury et al., 1998). Burnstock (1996b) put forward a unifying purinergic hypothesis for the initiation of pain by ATP acting via $\mathrm{P} 2 \mathrm{X}_{3}$ and $\mathrm{P} 2 \mathrm{X}_{2 / 3}$ receptors associated with causalgia, reflex sympathetic dystrophy, angina, migraine, and pelvic and cancer pain. This has been followed by an increasing number of papers expanding on this concept for acute, inflammatory, neuropathic, and visceral pain (see reviews by Burnstock and Wood, 1996; Chizh and Illes, 2000; Burnstock, 2001c; Dunn et al., 2001; Cooke et al., 2003; Gu, 2003; Inoue et al., 2003; Jarvis, 2003; Sawynok and Liu, 2003; Ueda and Rashid, 2003; North, 2004). Sensory terminals are sensitive to ATP released from local cells during mechanical stress and to $\alpha, \beta$ meATP in the tongue (Rong et al., 2000), tooth pulp (Alavi et al., 2001; Renton et al., 2003), bladder (Cockayne et al., 2000; Vlaskovska et al., 2001; O'Reilly et al., 2002; Rong et al., 2002), ureter (Knight et al., 2002; Rong and Burnstock, 2004), gut (Wynn et al., 2003, 2004), and uterine cervix (Papka et al., 2005). Both P2X (homomultimer) and $\mathrm{P}_{2 / 3}$ (heteromultimer) receptors mediate nociceptive afferent responses, but the proportions vary in different organs. $\mathrm{P}_{2} \mathrm{Y}_{1}$ receptors have also been demonstrated in a subpopulation of sensory neurons that colocalise with $\mathrm{P}_{2} \mathrm{X}_{3}$ receptors (Ruan and Burnstock, 2003; Gerevich et al., 2004).

The search is on for selective $\mathrm{P}_{2} \mathrm{X}_{3}$ and $\mathrm{P} 2 \mathrm{X}_{2 / 3}$ receptor antagonists that do not degrade in vivo. PPADS is a nonselective P2 antagonist, but has the advantage that it associates and dissociates approximately 100 to 10,000 times more slowly than other known antagonists 
(Spelta et al., 2002). The trinitrophenyl-substituted nucleotide TNP-ATP is a very potent antagonist at both $\mathrm{P}_{2} \mathrm{X}_{3}$ and $\mathrm{P}_{2} \mathrm{X}_{2 / 3}$ receptors (Mockett et al., 1994; King et al., 1997; Virginio et al., 1998; Burgard et al., 2000; Honore et al., 2002). A-317491 is a potent and selective non-nucleotide antagonist of $\mathrm{P} 2 \mathrm{X}_{3}$ and $\mathrm{P} 2 \mathrm{X}_{2 / 3}$ receptors, and it reduces chronic inflammatory and neuropathic pain in the rat (Jarvis et al., 2002, 2004; McGaraughty et al., 2003). Antisense oligonucleotides have been used to down-regulate the $\mathrm{P}_{2} \mathrm{X}_{3}$ receptor, and in models of neuropathic (partial sciatic nerve ligation) and inflammatory (complete Freund's adjuvant) pain, inhibition of the development of mechanical hyperalgesia as well as significant reversal of established hyperalgesia, were observed within 2 days of treatment (Barclay et al., 2002; Honore et al., 2002; Stone and Vulchanova, 2003). $\mathrm{P}_{2} \mathrm{X}_{3}$ antisense oligonucleotides or antagonists appear to be less effective for treating discogenic (lumbar intervertebral disc) than cutaneous tissue pain (Aoki et al., 2003). Combined antisense and RNA interference-mediated treatment for specific inhibition of the recombinant rat $\mathrm{P} 2 \mathrm{X}_{3}$ receptor appears to be promising for pain therapy (Hemmings-Mieszczak et al., 2003). P2X $\mathrm{X}_{3}$ doublestranded short interfering RNA relieves chronic neuropathic pain and opens up new avenues for therapeutic pain strategies in man (Dorn et al., 2004). Cytotoxic targeting using the IB4-saporin conjugate of isolectin IB4-binding nociceptive sensory neurons decreases the severity to noxious stimuli (Vulchanova et al., 2001; Nishiguchi et al., 2004). Antagonism of $\mathrm{P}_{2} \mathrm{X}_{1}$ and $\mathrm{P} 2 \mathrm{X}_{3}$ receptors by phenol red has recently been reported (King et al., 2005) and shown to cause significant increases in the pressure and volume threshold required to initiate the micturition reflex in female urethra-anesthetized rats (King et al., 2004). Modulation of neurotransmission through $\mathrm{P}_{2} \mathrm{X}_{3}$ receptors in central and peripheral nervous systems may contribute to the anesthesia and analgesia produced by barbiturates (Kitahara et al., 2003). Tetramethylpyrazine, a traditional Chinese medicine used as an analgesic for dysmenorrhea, was shown to block $\mathrm{P}_{2} \mathrm{X}_{3}$ receptor signaling, inhibit significantly the first phase of nociceptive behavior induced by $5 \%$ formalin, and attenuate slightly the second phase in the rat hindpaw pain model (Liang et al., 2004, 2005). Interactions between vanilloid and metabotropic P2Y receptors are also being explored in terms of treatments for chronic pain (Premkumar, 2001) and thermal hypersensitivity (Moriyama et al., 2003). It has been reported recently that antagonism of spinal $\mathrm{P}_{2} \mathrm{X}_{3} / \mathrm{P} 2 \mathrm{X}_{2 / 3}$ receptors results in an indirect activation of the opioid system to alleviate inflammatory hyperalgesia and chemogenic nociception (McGaraughty et al., 2005).

For neuropathic pain, the tactile allodynia that follows peripheral nerve injury is reduced by A-134974, a novel adenosine kinase inhibitor acting at spinal sites (Zhu et al., 2001). Endogenous ATP acting on P2X receptors appears to be necessary for the induction of the postoperative pain characterized by mechanical allodynia (Tsuda et al., 2000, 2001). Up-regulation of $\mathrm{P}_{1} \mathrm{Y}_{1}$ receptor expression in the DRG occurs after transection of sciatic nerves (Xiao et al., 2002). P2X $\mathrm{X}_{4}$ receptors are induced in spinal microglia that appear to gate tactile allodynia after nerve injury (Tsuda et al., 2003, 2005; Inoue et al., 2004, 2005). Intraspinal administration of p38 inhibitor suppressed allodynia, which suggests that neuropathic pain hypersensitivity depends on the activation of the p38 signaling pattern in microglia in the dorsal horn following peripheral nerve injury (Inoue et al., 2003). Suramin inhibits spinal cord microglia activation and long-term hyperalgesia induced by inflammation produced by formalin injection (Wu et al., 2004; Guo et al., 2005). Analgesic effects with intrathecal administration of P2Y receptor agonists UTP and UDP in normal and the neuropathic pain rat model have been reported, suggesting that $\mathrm{P}_{2} \mathrm{Y}_{2}$ (and/or $\mathrm{P}_{2} \mathrm{Y}_{4}$ ) and $\mathrm{P} 2 \mathrm{Y}_{6}$ receptors produce inhibitory effects in spinal pain transmission (Okada et al., 2002). Disruption of the $\mathrm{P}_{2} \mathrm{X}_{7}$ receptor gene abolishes chronic inflammatory and neuropathic pain (Chessell et al., 2005). Purinergic mechanisms are also beginning to be explored in relation to cancer pain (Burnstock, 1996; Cain et al., 2001; Mantyh et al., 2002; Gilchrist et al., 2005).

\section{Diseases of Special Senses}

1. Eye. Purinergic signaling is widespread in the eye (Pintor, 2000) and novel therapeutic strategies are being developed for glaucoma, dry eye, and retinal detachment (Pintor et al., 2003a). P2Y receptors on human corneal epithelial cells appear to play a critical role in the injuryrepair process (Klepeis et al., 2004).

ATP, acting via both $\mathrm{P} 2 \mathrm{X}$ and $\mathrm{P} 2 \mathrm{Y}$ receptors, modulates retinal neurotransmission, affecting retinal blood flow and intraocular pressure. The ATP analog $\beta, \gamma-$ methylene ATP is more effective in reducing intraocular pressure $(40 \%)$ than muscarinic agonists such as pilocarpine (25\%) and $\beta$-adrenoceptor blockers (30\%), raising the potential for the use of purinergic agents in glaucoma (Pintor and Peral, 2001). Dinucleoside polyphosphates acting via $\mathrm{P}_{2} \mathrm{Y}_{1}$ receptors on trabecular network cells increase aqueous humor outflow and may be another target for antiglaucomatous drugs (Soto et al., 2005). Suramin, a P2 receptor antagonist, has been shown to inhibit the fibrotic wound healing reactions that sometimes follow trabeculectomies for surgically treating eyes with glaucoma (Mietz et al., 1998). Topical application of $\mathrm{Ap}_{4} \mathrm{~A}$ has been proposed for the lowering of intraocular pressure in glaucoma (Pintor et al., 2003b). The formation of $\mathrm{P}_{2} \mathrm{X}_{7}$ receptor pores and apoptosis is enhanced in retinal microvessels early in the course of experimental diabetes, suggesting that purinergic vasotoxicity may play a role in microvascular cell death, a feature of diabetic retinopathy (Sugiyama et al., 2004). 
$\mathrm{P}_{2} \mathrm{Y}_{2}$ receptor activation increases salt, water, and mucus excretion and thus represents a potential treatment for dry eye conditions (Murakami et al., 2000; Yerxa, 2001). In the pigmented layer of the retina, $\mathrm{P}_{2} \mathrm{Y}_{2}$ receptor activation promotes fluid absorption and may be involved in retinal detachment. INS37217, a longlasting synthetic $\mathrm{P} 2 \mathrm{Y}_{2}$ receptor agonist, stimulates the retinal pigment epithelium by activating $\mathrm{P}_{2} \mathrm{Y}_{2}$ receptors at the apical membrane, and in vivo treatment enhances the rate of subretinal fluid reabsorption in experimentally induced retinal detachments and may be useful for treating a variety of retinal diseases that result in fluid accumulation in the subretinal space (Maminishkis et al., 2002). Reactive responses of Müller cells occur within $24 \mathrm{~h}$ of retinal detachment. Suramin inhibits some of these responses and may provide a therapeutic candidate to limit the detrimental effects of immune cell activation and Müller cell gliosis during retinal detachment (Uhlmann et al., 2003).

ATP and UTP restore the rates of both net $\mathrm{Cl}^{-}$and fluid secretion in adenovirus type 5-infected conjunctival tissues and are considered as potential therapeutic modulators for the treatment of various transport defects encountered in ocular tissues in diseased and/or inflamed states (Kulkarni et al., 2003). UTP and $\mathrm{Ap}_{4} \mathrm{~A}$ accelerate wound healing in the rabbit cornea, by regulating the rate of epithelial cell migration (Pintor et al., 2004).

The UPL rat is a dominant hereditary cataract model derived from Sprague-Dawley rats and has been used to show that $\mathrm{Ca}^{2+}$-ATPase expression increases, whereas ATP control decreases in lenses during the development of the cataract and opacification; disulfiram and aminoguanidine, which inhibit inducible NO and scavenge reactive oxygen species, attenuate the decrease in ATP, resulting in a delay in cataract development (Nabekura et al., 2004).

A recent article has raised the possibility that alterations in sympathetic nerves may underlie some of the complications observed in diabetic retinopathy (Wiley et al., 2005); ATP is well established as a cotransmitter in sympathetic nerves.

2. Ear. In the auditory system ATP, acting via P2Y receptors, depresses sound-evoked gross compound action potentials in the auditory nerve and the distortion produces otoacoustic emission, the latter being a measure of the active process of the outer hair cells (Housley, 2000; Sueta et al., 2003). P2X splice variants are found on the endolymphatic surface of the cochlear endothelium, an area associated with sound transduction. Both P2X and P2Y receptors have been identified in the vestibular system (Xiang et al., 1999). ATP may regulate fluid homeostasis, cochlear blood flow, hearing sensitivity and development, and thus may be useful in the treatment of Ménière's disease, tinnitus, and sensorineural deafness.
Sustained loud noise produces an up-regulation of $\mathrm{P}_{2} \mathrm{X}_{2}$ receptors in the cochlea, particularly at the site of outer hair cell sound transduction. $\mathrm{P}_{2} \mathrm{X}_{2}$ expression is also increased in spiral ganglion neurons, indicating that extracellular ATP acts as a modulator of auditory neurotransmission that is adaptive and dependent on the noise level (Wang et al., 2003a). Excessive noise can irreversibly damage hair cell stereocilia leading to deafness. Data have been presented showing that release of ATP from damaged hair cells is required for $\mathrm{Ca}^{2+}$ wave propagation through the support cells of the organ of Corti, involving $\mathrm{P} 2 \mathrm{Y}$ receptors, and this may constitute the fundamental mechanism to signal the occurrence of hair cell damage (Munoz et al., 2001; Gale et al., 2004). ATP is claimed to mitigate the effects of noise trauma (Jakobi et al., 1977; Sugahara et al., 2004), although the mechanisms involved are not clear.

3. Nasal Organs. Purinergic receptors have been described in the nasal mucosa, including the expression of $\mathrm{P}_{2} \mathrm{X}_{3}$ receptors on olfactory neurones (Gayle and Burnstock, 2005). Enhanced sensitivity to odors in the presence of $\mathrm{P} 2$ purinergic antagonists suggests that lowlevel endogenous ATP normally reduces odor responsiveness (Hegg et al., 2003a). It appears that the induction of heat-shock proteins by noxious odor damage can be prevented by the in vivo administration of $\mathrm{P} 2$ receptor antagonists (Hegg et al., 2003b). The predominantly suppressive effect of ATP in odor responses could play a role in the reduced odor sensitivity that occurs during acute exposure to noxious fumes and may be a novel neuroprotective mechanism.

\section{Immune System and Inflammation}

ATP and adenosine are released at sites of inflammation. ATP is involved in the development of inflammation through a combination of actions: release of histamine from mast cells, provoking production of prostaglandins; and the production and release of cyokines from immune cells (Di Virgilio et al., 1998). In contrast, adenosine exerts anti-inflammatory actions. $\mathrm{P}_{2} \mathrm{X}_{7}$ and $\mathrm{P} 2 \mathrm{Y}_{1}$ and $\mathrm{P} 2 \mathrm{Y}_{2}$ receptors located on inflammatory and immune cells play a pivotal role in inflammation and immunomodulation (Di Virgilio et al., 1998; Luttikhuizen et al., 2004). In addition, NTPDases have effects on immune reactions (Robson et al., 2001). NTPDase1 deficiency appears to have two opposing impacts on nucleotide-mediated signaling, that is, inhibition via desensitization of some, but not all, P2 receptors and augmentation of certain other responses via impaired hydrolysis of their ligands. Consequently, there are defects in dendritic cell function, antigen presentation, T-cell responses to haptens (type IV hypersensitivity reactions), and delayed cellular rejection responses under partial costimulation blockade in NTPDase1-null mice. 
In addition to the roles of purines in inflammation, they have a broad range of functions carried out through purinergic receptors on immune cells, including killing intracellular pathogens by inducing apoptosis of host macrophages, chemoattraction, and cell adhesion (Burnstock, 2001d; Di Virgilio et al., 2001). Purinergic compounds may turn out to be useful for the treatment of neurogenic inflammation, rheumatoid arthritis, and periodontitis (Dubyak and El Moatassim, 1993).

ATP-induced apoptosis in macrophages via $\mathrm{P}_{2} \mathrm{X}_{7}$ receptors, also results in killing of the mycobacteria contained within them, in contrast, to the macrophage apoptosis produced by other agents. Elucidation of the bacterial killing mechanism initiated by the $\mathrm{P}_{2} \mathrm{X}_{7}$ receptor may help to devise new strategies to combat the most potent and enduring of human pathogens (Lammas et al., 1997; Saunders et al., 2003). Infection with Mycobacterium tuberculosis causes macrophages to release ATP, which leads to oxygen radical production, providing antibacterial effects at sites of infection (Sikora et al., 1999). In later studies, it was shown that the ATPinduced bactericidal activity toward virulent $M$. tuberculosis requires an increase in cytosolic $\mathrm{Ca}^{2+}$ in infected macrophages, and it was hypothesized that the $\mathrm{Ca}^{2+}$ dependence was linked to promotion of phagosome-lysosome fusion (Kusner and Barton, 2001; Fairbairn et al., 2001). The $P 2 X_{7}$ receptor plays a fundamental role in lipopolysaccharide signal transduction and activation of macrophages and may therefore represent a therapeutic target for Gram-negative bacterial septicemia (Sommer et al., 1999). Vibrio cholerae, the causative organism of the intestinal disease cholera, secretes enzymes that lead to ATP degradation; this may allow the pathogen to evade the immune system by reducing the apoptotic actions of the $\mathrm{P}_{2} \mathrm{X}_{7}$ receptor (Punj et al., 2000). Evidence has been presented to support the view that, whereas the cytotoxic actions of ATP on macrophages were via $\mathrm{P}_{2 \mathrm{X}}$ receptors, the bacteriocidal effects of ATP (and $\mathrm{UTP}$ ) were probably via $\mathrm{P}_{2} \mathrm{Y}_{2}$ receptors (Stober et al., 2001). It is conceivable that various pathogenic bacteria might secrete adenine nucleotide-interconverting enzymes during host cell infection to modulate host cell purinergic receptors to their own advantage (Yamada and Chakrabarty, 2004). Lesional accumulation of macrophages expressing $\mathrm{P}_{2} \mathrm{X}_{4}$ receptors in rat CNS during experimental autoimmune encephalomyelitis has been described recently, and it was suggested that $\mathrm{P}_{2} \mathrm{X}_{4}$ receptors might be valuable markers to dissect the local monocyte heterogeneity in autoimmune disease (Guo and Schluesener, 2005). ATP moderates anti-IgE-induced release of histamine from lung mast cells and may therefore be mechanistically involved in human allergic/ asthmatic reactions (Schulman et al., 1999). Alveolar macrophages express $\mathrm{P} 2 \mathrm{X}_{7}$ receptors, which upon stimulation trigger proinflammatory responses, including activation of IL-1 to IL-6 cytokines and granulomatous reactions (Lemaire and Leduc, 2004). In contrast, ATP and $\mathrm{ADP}$ inhibit cytokine generation by human mast cells through P2Y receptors and could present a novel therapeutic target for asthma, arthritis and other disorders with a prominent contribution from mast cells and their products (Feng et al., 2004).

Extracellular ATP inhibits the activation of $\mathrm{CD} 4^{+} \mathrm{T}$ lymphocytes via P2Y receptors, which suggests a novel therapeutic target for topical immunosuppression in eye, skin, or airway inflammatory disease (Duhant et al., 2002). In addition to the apoptosis mediated by $\mathrm{P}_{2} \mathrm{X}_{7}$ receptors, a lower level of activation sometimes results in cell proliferation; it has been suggested that the expression and function of $\mathrm{P}_{2} \mathrm{X}_{7}$ receptors on $\mathrm{B}$ lymphocytes may correlate with the severity of B-cell chronic lymphocytic leukemia (Adinolfi et al., 2002).

During the acute phase of Trypanosoma cruzi infection, the etiologic agent of Chagas' disease, thymic atrophy occurs; ATP also induces cell death in $\mathrm{CD} 4^{+} / \mathrm{CD} 8^{+}$ double-positive thymocytes and may play a central role in thymus atrophy during T. cruzi infection (MantuanoBarradas et al., 2003). Infection by the parasitic blood fluke Schistosoma mansoni also leads to thymic atrophy. The cloning and characterization of a P2X receptor (schP2X) from S. mansoni provide the first example of a nonvertebrate ATP-gated ion channel and may provide an alternative drug target for the treatment of schistosomiasis (Agboh et al., 2004).

A novel mechanism by which ATP, probably via P2Y 11 receptors, can regulate the trafficking of specific dendritic cell populations has been described (Schnurr et al., 2003). The migration of dendritic cells from the site of antigen capture to lymphoid tissue is a prerequisite for the induction and regulation of immune responses. Therefore, ATP-mediated inhibition of migration could play an important role in inflammatory disease and cancer. Targeting of $\mathrm{P} 2 \mathrm{Y}_{11}$ receptors may provide a new therapeutic strategy to improve the migration of dendritic cells to induce the trafficking of antigen from the vaccine site to the draining lymph nodes.

Allopurinal and captopril have a therapeutic effect in granulomatous disorders, such as sarcoidosis, by a direct action on monocyte/macrophage lineage cells partly by down-regulation of intracellular adhesion molecular- 1 and $\mathrm{P}_{2} \mathrm{X}_{7}$ receptors (Mizuno et al., 2004). ATP and UTP have been shown to be potent stimulators of human hematopoietic stem cells both in vitro and in vivo (Lemoli et al., 2004). Thus, these extracellular nucleotides may provide a novel and powerful tool to modulate hematopoietic stem cell function to increase the number of transplantable cells in vivo in the event of bone marrow failure. $\mathrm{P}_{2} \mathrm{X}_{7}$ receptors control endocannabinoid production by microglia cells and might constitute promising therapeutics to temper exacerbated microinflammatory responses and allied cell damage (Witting et al., 2004). 


\section{Endocrinology, Diabetes, and Obesity}

Purinoceptors are widely expressed in endocrine glands (Burnstock and Knight, 2004). For example, ATP and UTP increase cytosolic free calcium in human thyrocytes (Schofl et al., 1995), ATP modulates aldosterone production by adrenal cortex (Szalay et al., 1998), ATP regulates prolactin release from the anterior pituitary (Stojilkovic et al., 2000) and vasopressin and oxytocin secretion from the posterior pituitary (Sperlágh et al., 1999); ATP stimulates insulin release from the endocrine pancreas (Coutinho-Silva et al., 2001); ATP and UTP inhibit estradiol and progesterone secretion from the ovary (Tai et al., 2001) and mediate increases in intracellular calcium in Sertoli cells from testis (Ko et al., 2003). Ovariectomy significantly increased the hydrolysis of ATP, ADP, and AMP in rat blood serum, whereas estradiol replacement therapy significantly decreased the hydrolysis of adenine nucleotides, suggesting a relationship between ecto-ATPases and the hormonal system (Pochmann et al., 2004).

A diversity of actions of purines in the pituitary gland have been described, including trophic effects and cytokine production as well as actions in hormone release, with implications for pathological as well as physiological states (Rees et al., 2003). 5'-Nucleotidase activity is increased in synaptosomes from hippocampus and cerebral cortex of hypothyroid rats and may be related to the cognitive disorders found in hypothyroidism (Bruno et al., 2005a). 5'-Nucleotidase activity is also altered in platelets by hypo- and hyperthyroidism and may represent an additional mechanism by which disturbances related to thyroid hormones are associated with some vascular diseases (Bruno et al., 2005b).

\section{A. Diabetes}

Early studies from the laboratory of Loubatière-Mariani et al. (1997) showed that P2Y receptors are present on pancreatic $\beta$-cells and are involved in insulin secretion. ATP stimulates pancreatic insulin release through a glucose-dependent P2Y receptor-mediated mechanism and also modulates insulin secretion through interactions with ATP-sensitive potassium channels in islet $\beta$-cells. Biotin enhances ATP synthesis in pancreatic islets, resulting in reinforcement of glucose-induced insulin secretion (Sone et al., 2004).

P2Y purinoceptors appear to be impaired in fibroblasts from type 2 diabetic patients, which results in reduced glucose uptake via the glucose transporter GLUT 1, suggesting that P2Y receptors may be candidate targets for the design of innovative antidiabetic drugs (Solini et al., 2003). Hormone-specific defects in insulin regulation of ATPase that may contribute to their insulin resistance are seen in non-insulin-dependent diabetic rats (Levy et al., 1994).

A feature of diabetic retinopathy is the apoptotic death of microvascular pericytes and endothelial cells; there appears to be an enhancement of $\mathrm{P} 2 \mathrm{X}_{7}$ receptorinduced pore formation and apoptosis on the retinal microvasculature in early diabetes (Sugiyama et al., 2004). In streptozotocin-induced diabetic animals, $\mathrm{P}_{2} \mathrm{X}_{7}$ receptor expression, located in glucagon-containing $\alpha$-cells in pancreatic islets, increases, and the expression migrates centrally to take the place of the insulin-containing $\beta$-cells, although the functional significance of this is not known (Coutinho-Silva et al., 2003). The potential role of purinergic compounds as novel treatments for diabetes has yet to be explored. Stimulation of insulin secretion and improvement of glucose tolerance in rats and dogs by the $\mathrm{P} 2 \mathrm{Y}$ receptor agonist adenosine5 '-(2-thiodiphosphate) has been claimed (Hillaire-Buys et al., 1993).

\section{B. Obesity}

ATP, released as a cotransmitter from sympathetic nerves, has been shown to stimulate brown adipocytes (Lee and Pappone, 1997; Omatsu-Kanbe et al., 2002). Deficits in receptor regulation, transporter mobilization, and adipocyte hormone secretion are all thought to contribute to the pathology of obesity (Flier, 1995; Schmidt and Loffler, 1998). Stimulation of lipogenesis in rat adipocytes by ATP, which regulates fat stores independently from established hormones has been reported (Schodel et al., 2004). A recent article presents evidence that adipocytes express two different P2Y receptor subtypes and that activation of $\mathrm{P}_{2} \mathrm{Y}_{11}$ receptors might be involved in inhibition of insulin-stimulated lepton production and stimulation of lipolysis (Lee et al., 2005). Some of the effects of ATP are caused by its breakdown product, adenosine, which has been known for a long time to be involved in the activities of adipocytes (see Fredholm, 1981).

\section{Gastroenterology}

Purinergic signaling plays a major role in different activities of the gut (Burnstock, 2001b; Galligan, 2002; Giaroni et al., 2002; Lecci et al., 2002; Nassauw et al., 2002; Poole et al., 2002; Bertrand, 2003; Kadowaki et al., 2003; Xiang and Burnstock, 2004a,b). ATP is a cotransmitter in NANC nerves responsible for the inhibitory phase in peristalsis, it participates in synaptic transmission in the myenteric and submucosal ganglia, and it is involved in vascular control of the gastrointestinal tract and in the control of mucosal secretion. Both glial cells (Kimball and Mulholland, 1996; Vanderwinden et al., 2003) and the interstitial cells of Cajal (Burnstock and Lavin, 2002) express P2 receptors, although their roles have yet to be clarified.

A limited number of studies have been conducted to date on changes in purinergic signaling in the diseased gut. ATP and adenosine have been implicated in the development of gastric ulcers, Hirschsprung's and Chagas' diseases, ischemia and colonic tumors (Burnstock, 
2001c). Extracellular nucleotides and their receptors have been implicated in the pathogenesis of inflammatory bowel disease (IBD) (Somers et al., 1998). T cells are thought to play a primary role in the induction of epithelial cell damage in IBD, and the $\mathrm{P}_{2} \mathrm{Y}_{6}$ receptor was found to be highly expressed on the $\mathrm{T}$ cells infiltrating IBD, but absent in T cells of unaffected bowel. This suggests that the $\mathrm{P} 2 \mathrm{Y}_{6}$ receptor and its selective agonist, UDP, may play a role in the pathogenesis of IBD. Later articles have shown that $\mathrm{P}_{2} \mathrm{Y}_{6}$ receptors are involved in monocytic release of IL-8 and stimulation of $\mathrm{NaCl}$ secretion (Kottgen et al., 2003). During inflammation of the gastrointestinal tract, glial cells proliferate and produce cytokines; thus, $\mathrm{P}_{2} \mathrm{X}_{7}$ receptors may play a role in the response of enteric glia to inflammation (Vanderwinden et al., 2003). $\mathrm{P} 2 \mathrm{X}_{3}$ purinergic signaling enhancement in an animal model of colitis has been described (Wynn et al., 2004). $\mathrm{P} \mathrm{X}_{3}$ receptor expression is increased in the enteric plexuses in human irritable bowel syndrome, suggesting a potential role in dysmotility and pain (Yiangou et al., 2001), and the possibility that P2X receptors are potential targets for the drug treatment of irritable bowel syndrome has been raised (Galligan, 2004). Bile induces ATP depletion and contributes to the early mucosal permeability alteration and barrier lesions that occur during experimental esophageal reflux (Szentpali et al., 2001). P2X $\mathrm{X}_{3}$ immunohistochemistry has been demonstrated in aganglionic bowel in Hirschsprung's disease, suggesting that the sensory nerves may form a significant proportion of its hypertrophic innervation (Facer et al., 2001). P2Y receptors on smooth muscle and ATP production in myenteric neurons increase in postoperative ileus, probably contributing to delayed colonic transit (Wang et al., 2004a). Recent reviews have highlighted the potential of purinergic drugs for the treatment of functional bowel disorders and visceral pain (Holzer, 2001; Kirkup et al., 2001; Galligan, 2004). Intestinal epithelial cells from patients with cystic fibrosis fail to consistently conduct $\mathrm{Cl}^{-}$in response to ATP and UTP that elevate intracellular $\mathrm{Ca}^{2+}$ and this may be of value in the design of treatments to ameliorate gastrointestinal symptoms of cystic fibrosis (Smitham and Barrett, 2001).

Intrinsic sensory neurons in the submucous plexus of the gut, as well as extrinsic sensory nerves, show positive immunoreactivity for $\mathrm{P}_{2} \mathrm{X}_{3}$ receptors (Xiang and Burnstock, 2004b). It has been proposed (Burnstock, 2001b) that during moderate distension, low threshold intrinsic enteric sensory fibers may be activated via $\mathrm{P}_{2} \mathrm{X}_{3}$ receptors by ATP released from mucosal epithelial cells, leading to reflexes concerned with propulsion of material down the gut. Studies showing that peristalsis is impaired in the small intestine of mice lacking the $\mathrm{P}_{2} \mathrm{X}_{3}$ receptor subunit support this view (Bian et al., 2003). In contrast, during substantial (colic) distension associated with pain, higher threshold extrinsic sensory fibers may be activated by ATP released from the mu- cosal epithelia; these fibers pass messages through the DRG to pain centers in the CNS (Wynn et al., 2003, 2004). A recent study suggests that peripheral sensitization of $\mathrm{P} 2 \mathrm{X}_{3}$ receptors on vagal and spinal afferents in the stomach may contribute to dyspeptic symptoms and the development of visceral hyperalgesia (Dang et al., 2005).

In the liver, purinergic receptors have been identified in the plasma membrane of the two principal epithelial cell types that form the bile-secreting unit, namely, hepatocytes, which constitute the liver parenchymal cells, and cholangiocytes, which line the lumen of intrahepatic bile ducts (Nathanson et al., 2001; Feranchac and Fitz, 2003). Activation of the receptors has been linked to several fundamental responses important to cellular metabolism, ion channel activation, cell volume regulation, and bile formation. It is suggested that pharmacological modulation of ATP release and purinergic signaling might provide novel strategies for the management of cholestasis and other disorders characterized by impaired bile flow. Purinergic receptors are present on both quiescent and activated hepatic stellate cells; quiescent cells express $\mathrm{P}_{2} \mathrm{Y}_{2}$ and $\mathrm{P}_{2} \mathrm{Y}_{4}$ receptors activated by UTP and ATP, whereas activated cells express $\mathrm{P}_{2} \mathrm{Y}_{6}$ receptors activated by UDP and ATP (Dranoff et al., 2004). It was speculated by these authors that the P2Y receptors on satellite cells might be an attractive target to prevent or treat liver fibrosis, via regulation of procollagen-1 transcription. ATP has been shown recently to rapidly activate multiple components of the c-Jun $\mathrm{NH}_{2}$-terminal kinase cascade, a central player in hepatocyte proliferation and liver regeneration (Thevananther et al., 2004). This study identifies extracellular ATP as a hepatic mitogen with implications about the regulation of liver growth and repair. Sympathetic nerves using NA and ATP as cotransmitters alleviate immunemediated experimental hepatitis in the mouse; it is speculated that nerve-immune cell interactions may offer novel therapeutic strategies in immune and inflammatory liver diseases (Neuhuber and Tiegs, 2004).

The effect of ATP on salivary glands has been recognized since 1982. Both P2X and P2Y subtypes are expressed and opportunities for utilization of these receptors as pharmaceutical targets for diseases involving salivary gland dysfunction appear promising (Turner et al., 1999; Arreola and Melvin, 2003).

\section{Urogenital Diseases}

\section{A. Kidney and Ureter}

There is a substantial presence of purinoceptors in different regions of the nephron, the glomerulus, and renal vascular system in the kidney, including subtypes involved in the regulation of renin secretion, glomerular filtration, and transport of water, ions, nutrients, and toxins (Chen and Chen, 1998; Unwin et al., 2003; Bailey et al., 2004; Shirley et al., 2005) (Fig. 2). The distribution 


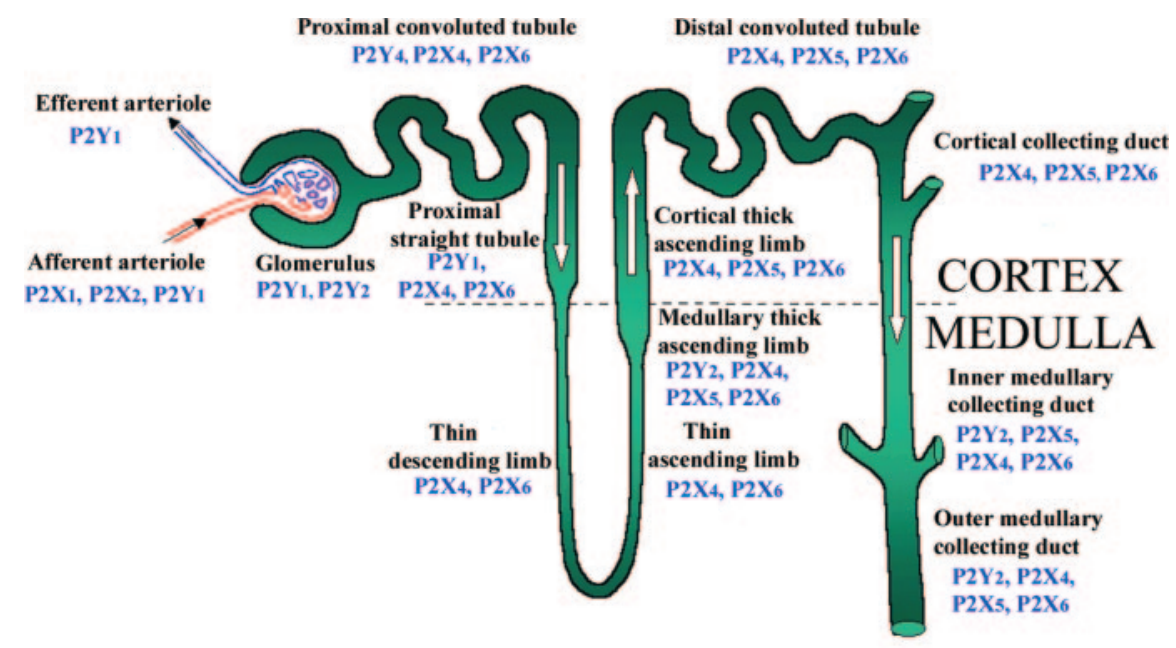

FIG. 2. Summary of the nephron segments and the distribution of P2 receptor subtypes. Based on Turner et al. (2003), with permission from S. Karger AG (Basel, Switzerland).

of NTPDase1 and NTPDase2 parallels the distribution of $\mathrm{P} 2$ receptors in the kidney and is likely to influence physiological as well as pathophysiological events in the kidney (Kishore et al., 2005). ATP and adenosine have been used to protect kidneys from renal ischemic-reperfusion injury, and are being explored for the treatment of chronic renal failure and transplantation-induced erythrocytosis (Jackson, 2001). It has been proposed that luminal P2 receptors in the nephron are part of an epithelial "secretory" defense mechanism against bacteria or harmful particles involved in the regulation of cell volume when transcellular solute transport is out of balance. P2Y receptors mediate renin secretion (Churchill and Ellis, 1993). ATP released from macula densa cells serves as a major paracrine agent, mediating tubuloglomerular feedback signals to regulate afferent arteriolar resistance (Nishiyama and Navar, 2002). ATP exerts a dual effect on mesangial extracellular matrix production, stimulatory probably via $\mathrm{P}_{2} \mathrm{X}_{7}$ receptors and inhibitory via a P2Y receptor (Solini et al., 2005). In the presence of elevated ATP levels in inflammatory or ischemic conditions, extracellular matrix proteins accumulate due to functional predominance of P2X receptors. This mechanism might participate in the pathogenesis of mesangial expression that occurs in diabetes.

Cyclosporine is a potent immunosuppressive agent, but its use has been limited by the side effect of nephrotoxicity; however, ATP treatment after verapamil pretreatment greatly reduces the nephrotoxic potential (Sumpio et al., 1987). The P2 receptor antagonist, PPADS, has been shown to be an effective inhibitor of mesangial cell proliferation in an experimental rat model of mesangial proliferative glomerulonephritis (Rost et al., 2002).

In polycystic kidney disease, tubules are altered, leading to dilated tubules or cysts encapsulated by a single monolayer of renal epithelium. It has been postulated that autocrine purinergic signaling enhances cyst ex- pansion and accelerates disease progression (Schwiebert et al., 2002). An increase in expression of $\mathrm{P}_{2} \mathrm{Y}_{2}, \mathrm{P}_{2} \mathrm{Y}_{6}$, and $\mathrm{P}_{2} \mathrm{X}_{7}$ receptors has been reported in cystic tissue from the Han:SPRD cy/ $/^{+}$rat model of autosomal dominant polycystic kidney disease (Turner et al., 2004a). P2 antagonists and inhibitors of ATP release are being explored as therapeutic agents to treat this disease. A recent article suggests that ATP may inhibit pathological renal cyst growth through $\mathrm{P}_{2} \mathrm{X}_{7}$ signaling (Hillman et al., 2004). There is increased glomerular expression of $\mathrm{P} \mathrm{X}_{7}$ receptors in two rat models of glomerular injury due to diabetes and hypertension (Vonend et al., 2004). A further study of human and experimental glomerulonephritis also shows increase in $\mathrm{P}_{2} \mathrm{X}_{7}$ receptor expression (Turner et al., 2004b).

Administration of ATP complexed with $\mathrm{MgCl}_{2}$ has been used for many years to improve postischemic and drug-induced glomerular and tubular function (Sumpio et al., 1984, 1985). There is convincing evidence that there is increased sympathetic activity in renal disease, especially ischemia (Joles and Koomans, 2004). Because ATP is established as a cotransmitter with NA in sympathetic nerves, this may be a source of enhanced ATP in these conditions.

The potential role of $\mathrm{P} 2 \mathrm{X}_{3}$ receptors in mechanosensory transduction has already been mentioned in relation to the bladder (Burnstock, 2001e). However, there is increasing evidence that this is not an isolated phenomenon and that ATP released from the epithelial lining of other organs including the ureter following distension may act on $\mathrm{P}_{2} \mathrm{X}_{3}$ receptors on afferent nerves in the subepithelial plexuses to provide sensory feedback and, in the case of the ureter, renal colic pain (see Fig. 2 and section II.B.). $\mathrm{P}_{2} \mathrm{X}_{3}$ receptors have been found on the suburothelial nerve plexus, and both the human and guinea pig ureter and urothelial cells have been shown to release ATP in a pressure-dependent fashion when the ureter is distended (Knight et al., 2002). This ATP 
release is abolished when the urothelium is removed, and sensory nerve-recording studies during ureteral distension demonstrate purinergic involvement, suggesting that specific $\mathrm{P}_{2} \mathrm{X}_{3}$ antagonists may have efficacy in alleviating renal colic (Rong and Burnstock, 2004).

\section{B. Lower Urinary Tract}

In the normal human bladder, atropine will block at least $95 \%$ of parasympathetic nerve-mediated contraction, indicating that its innervation is predominantly cholinergic; purinergic signaling is responsible for the atropine-resistant component of contraction (Burnstock, 2001e). There are a number of examples of the purinergic component of cotransmission increasing in pathological conditions (Abbracchio and Burnstock, 1998; Burnstock, 2001e). One is that purinergic nerve-mediated contraction of the human bladder is increased to $40 \%$ in pathophysiological conditions such as interstitial cystitis, outflow obstruction, idiopathic detrusor instability, and probably also neurogenic bladder (Wammack et al., 1995; Andersson, 1997; Andersson and Hedlund, 2002). ATP release from bladder epithelial cells from patients with interstitial cystitis is significantly greater than that from healthy cells (Sun and Chai, 2002), and there is a change in expression of both $\mathrm{P} 2 \mathrm{X}$ and $\mathrm{P} 2 \mathrm{Y}$ receptors in urothelial cells (Birder et al., 2004; Tempest et al., 2004). $\mathrm{P}_{2} \mathrm{X}_{1}$ receptor subtype expression markedly increased in obstructed bladder (Boselli et al., 2001) and in the absence of $\mathrm{P} 2 \mathrm{X}_{3}$ receptors in mouse knockouts, the bladder is hyperactive (Cockayne et al., 2000; Vlaskovska et al., 2001). Botulinum toxin A, which has antinociceptive effects in treating interstitial cystitis, inhibits distension-mediated urothelial release of ATP in conditions of bladder inflammation (Smith et al., 2004).

Purinergic signaling also plays a role in afferent sensation from the bladder (Wyndaele and De Wachter, 2003). ATP is released from urothelial cells when the bladder is distended (Ferguson et al., 1997; Vlaskovska et al., 2001). Sensory nerve recording has indicated that $\mathrm{P}_{2} \mathrm{X}_{3}$ receptors are involved in mediating the nerve responses to bladder distension, providing mechanosensory feedback involving both the micturition reflex and pain (Cockayne et al., 2000; Burnstock, 2001c; Vlaskovska et al., 2001; Rong et al., 2002). Purinergic agonists acting on $\mathrm{P}_{2} \mathrm{X}_{3}$ receptors in the bladder can sensitize bladder afferent nerves, and these effects mimic the sensitizing effect of cystitis induced by cyclophosphamide ( $\mathrm{Yu}$ and de Groat, 2004). Thus, $\mathrm{P} 2 \mathrm{X}_{3}$ receptors are a potential target for pharmacological manipulation in the treatment of both pain and detrusor instability.

In aging rats there is increased sensitivity of the bladder to ATP, but no change in response to acetylcholine or potassium chloride (Ferguson and Christopher, 1996). Comparable results showing increased purinergic, but not cholinergic, neurotransmission to aging human bladder smooth muscle have been found (Yoshida et al., 2001). Activation of $P 2$ receptors in the brain stem (both periaqueductal gray matter and Barrington's nucleus/ locus ceruleus) generates patterns of activity in the parasympathetic innervation of the bladder (Rocha et al., 2001). In patients with idiopathic detrusor instability, there is abnormal purinergic transmission in the bladder; this may account for some of the symptoms and provide a novel therapeutic target for treatment of overactive bladder (Andersson, 2002; O'Reilly et al., 2002). Voiding dysfunction involves $\mathrm{P}_{2} \mathrm{X}_{3}$ receptors in conscious chronic spinal cord-injured rats, which raises the possibility that $\mathrm{P} 2 \mathrm{X}_{3}$ antagonists might be useful for the treatment of neurogenic bladder dysfunction ( $\mathrm{Lu}$ et al., 2002). Drugs that alter ATP release or breakdown might also be therapeutic targets (Harvey et al., 2002; ChessWilliams, 2004). Copper inhibits purinergic transmission in the bladder and the copper(I) chelator, neocuproine, enhances bladder activity by facilitating purinergic excitatory responses (Göçmen et al., 2005). Expression of P2 receptors in bladder urothelium, as well as in nerve and smooth muscle, changes in a cat model of interstitial cystitis and may be linked with painful bladder symptoms (Birder et al., 2004). Recent reviews of management of detrusor dysfunction highlight the potential of therapeutic strategies related to purinergic signaling (Andersson, 2002; Kumar et al., 2003; Fry et al., 2004; Moreland et al., 2004; Nishiguchi et al., 2004; Ouslander, 2004; Yoshida et al., 2004; Birder, 2005; Rapp et al., 2005).

\section{Reproductive System}

Normal penile erectile function is dependent upon a delicate balance between contracting and relaxing factors in the corpus cavernosum smooth muscle, which are modulated by signaling from both nerves and endothelial cells. Evidence has accumulated to support a pivotal role for NANC neurotransmitters. NO plays a central role in mediating cavernosal smooth muscle relaxation, but other neurotransmitters can modulate this action and may play a role in erectile dysfunction. ATP potently relaxes cavernosal smooth muscle strips in vitro, an action pharmacologically consistent with P2Y receptors. Indeed, P2Y receptors are present on both cavernosal smooth muscle cells and endothelial cells, and ATP is released from a subpopulation of the cavernosal nerves. It appears that smooth muscle relaxation is caused by ATP acting directly on the cavernosal smooth muscle cells and indirectly is mediated by NO released from the endothelial cells. ATP-mediated cavernosal relaxation is impaired in diabetes mellitus (independent of $\mathrm{NO}$ ), implying that purinergic signaling may be involved in the pathophysiology of erectile dysfunction (Gür and Öztürk, 2000).

In humans, ATP induces a significant increase in sperm fertilizing potential and this provides a rationale for the use of ATP for treatment of spermatozoa during in vitro fertilization (Rossato et al., 1999). Knockout mice lacking $\mathrm{P}_{2} \mathrm{X}_{1}$ receptors appear normal, but fail to 
breed, and this is associated with loss of the purinergic component of sympathetic cotransmission in the vas deferens; these findings raise the possibility of developing nonhormonal ways of regulating male fertility (Dunn, 2000). Differential, stage-dependent immunostaining for P2X receptors during spermatogenesis in the adult rat testes has been described (Glass et al., 2001) and opens up the possibility of purinergic targets for both fertility and contraception. Evidence has been presented that glycolysis has an unexpectedly important role in providing the ATP required for sperm motility throughout the length of the sperm flagellum (Mukai and Okuno, 2004).

Synergistic effects of ATP and oxytocin in increasing $\left[\mathrm{Ca}^{2+}\right]_{\mathrm{i}}$ in mouse mammary myoepithelial cells suggest that activation of purinergic receptors may facilitate myoepithelial cell contraction in the milk ejection response (Nakano et al., 2001). $\mathrm{P}_{2} \mathrm{Y}_{2}$ receptors on apical and basolateral membranes appear to be involved (Blaug et al., 2003).

Micromolar concentrations of ATP stimulate a biphasic change in transepithelial conductance in the human uterine cervix, with phase 1 mediated by the $\mathrm{P}_{2} \mathrm{Y}_{2}$ receptor and phase II by the $\mathrm{P}_{2} \mathrm{X}_{4}$ receptor (Gorodeski, 2002). Given the potential role of ATP regulation of cervical paracellular permeability for human fertility, contraception, and health, these findings may have clinical significance and may lead to the development of drugs that can target specific signaling pathways in the cervix.

\section{Dermatology}

Purinergic signaling is much involved in keratinocyte turnover in skin epidermis: $\mathrm{P}_{2} \mathrm{Y}_{1}$ and $\mathrm{P} 2 \mathrm{Y}_{2}$ receptors in basal and parabasal layers mediate cell proliferation; $\mathrm{P}_{2} \mathrm{X}_{5}$ receptors in the granular layer mediate cell differentiation; and $\mathrm{P} 2 \mathrm{X}_{7}$ receptors at the stratum granulosum/stratum corneum border mediate apoptosis (Greig et al., 2003c). There are changes in the expression of P2 receptor subtypes in proliferative disorders of the epidermis, including psoriasis and scleroderma (Greig and Burnstock, unpublished data), and $\mathrm{P}_{2} \mathrm{Y}_{2}$ receptors have been proposed as a novel target for therapy of these disorders (Dixon et al., 1999). $\mathrm{P}_{2} \mathrm{Y}_{1}, \mathrm{P}_{2} \mathrm{Y}_{2}$, and $\mathrm{P}_{2} \mathrm{Y}_{4}$ receptors have also been identified on cultured keratinocytes (Cook et al., 1995) and on the HaCaT cell line (Burrell et al., 2003).

There is an increase of $\mathrm{P} 2 \mathrm{X}_{3}$ and $\mathrm{P} 2 \mathrm{X}_{2 / 3}$ nociceptive receptors on sensory nerve endings in inflamed skin (Hamilton et al., 2001), and antagonists are being developed as analgesics (see section II.B.). Data have been presented to support a pathogenic role for keratinocytederived ATP in irritant dermatitis (Mizumoto et al., 2003).

Changes in expression of purinergic receptors in the regenerating epidermis in wound healing have been de- scribed (Greig et al., 2003a). The P2X receptor antagonist, PPADS, has been shown to accelerate skin barrier repair and prevent epidermal hyperplasia induced by skin barrier disruption (Denda et al., 2002).

P2 agonists have significant immunostimulating effects on Langerhans cells, a subclass of dendritic cells in the epidermis (Granstein et al., 2005). The authors suggest that ATP, when released after trauma and infection, may act as an endogenous adjuvant to enhance the immune response and that P2 agonists may augment the efficacy of vaccines. Purinergic signaling involved in skin tumors is discussed in section XI.

\section{Respiratory Diseases}

P2 receptor purinergic compounds are being explored for the treatment of cystic fibrosis, to improve the clearance of secretions from the bronchi in chronic obstructive pulmonary disease, and for sputum expectoration in smokers (Gaba et al., 1986; Stutts and Boucher, 1999; Taylor et al., 1999; Mall et al., 2000; Yerxa, 2001). ATP and UTP stimulate $\mathrm{P}_{2} \mathrm{Y}_{2}$ receptor-mediated surfactant secretion and transepithelial chloride secretion in type II alveolar cells; there are abnormalities in this mechanism in cystic fibrosis (Yerxa, 2001; Bucheimer and Linden, 2004). Nucleotides also increase mucus secretion from goblet cells and increase the ciliary beat frequency of airway epithelial cells (Kemp et al., 2004). The longlasting $\mathrm{P}_{2} \mathrm{Y}_{2}$ receptor analog, INS 37217, increases the duration of mucociliary clearance and therefore has significant advantages over other $\mathrm{P}_{2} \mathrm{Y}_{2}$ agonists for the treatment of cystic fibrosis (Kellerman et al., 2002; Yerxa et al., 2002). P2X ${ }_{4}$ receptors have also been identified on lung epithelial cells and appear to be involved in regulation of ciliary beat, manipulation of which may also be of therapeutic benefit for cystic fibrosis (Zsembery et al., 2003). Recent evidence supports the view that vagal afferent purinergic signaling may be involved in the hyperactivity associated with asthma and chronic obstructive pulmonary disease (Adriaensen and Timmermans, 2004; Undem et al., 2004).

The use of theophylline, an adenosine-receptor antagonist, as an antiasthmatic agent has focused attention on the development of novel P1 receptor antagonists as asthmatic medications (Feoktistov and Biaggioni, 1996; Meade et al., 2001; Fozard and McCarthy, 2002; Polosa et al., 2002; Blackburn, 2003; Lee et al., 2003; Livingston et al., 2004; Zablocki et al., 2005). It has also been suggested that adenosine cooperates with inflammatory cytokines to stimulate mucin production in the asthmatic airway (McNamara et al., 2004).

Erythromycin is a widely used antibiotic for the treatment of upper and lower respiratory tract infections. One of the most conspicuous effects of erythromycin is the suppression of fluid secretion from bronchial epithelial cells in the treatment of bronchitis. Erythromycin has been shown to block the P2X receptor-mediated 
$\mathrm{Ca}^{2+}$ influx and may represent one mechanism by which it exerts its antisecretory effects in the treatment of chronic respirator tract infections (Zhao et al., 2000).

The ventrolateral medulla contains a network of respiratory neurons that are responsible for the generation and shaping of respiratory rhythm; it also functions as a chemoreceptive area mediating the ventilating response to hypercapnia. Evidence has been presented that ATP acting on $\mathrm{P}_{2} \mathrm{X}_{2}$ receptors expressed in ventrolateral medulla neurons influences these functions (Gourine et al., 2003). A potentially important role for P2 receptor synaptic signaling in respiratory motor control is suggested by the multiple physiological effects of ATP in hypoglossal activity associated with the presence of $\mathrm{P} 2 \mathrm{X}_{2}, \mathrm{P} 2 \mathrm{X}_{4}$, and $\mathrm{P}_{2} \mathrm{X}_{6}$ receptor $\mathrm{mRNA}$ in nucleus ambiguous and the hypoglossal nucleus (Collo et al., 1996; Funk et al., 1997) and microinjection of ATP into the caudal NTS of awake rats produces respiratory responses (Antunes et al., 2005).

The pneumovirus respiratory syncytial virus is the most common cause of lower respiratory tract disease in infants and children. It has a detrimental inhibitory effect on alveolar clearance, an effect that appears to be mediated by UTP, perhaps released by the bronchoalveolar epithelium in response to infection (Davis et al., 2004). This suggests that $\mathrm{P}_{2} \mathrm{Y}_{2}$ receptor antagonists may be useful for the treatment of severe respiratory syncytial virus broncheolitis.

Alveolar macrophages play a pivotal role in the development of chronic lung inflammatory reactions such as idiopathic pulmonary fibrosis, silicosis, asbestosis, hypersensitivity pneumonitis, sarcoidosis, and mycobacteria tuberculosis. $\mathrm{P} 2 \mathrm{X}_{7}$ receptors are expressed in alveolar macrophages, which upon stimulation activate the proinflammatory IL- 1 to IL-5 cytokine cascade and the formation of multinucleated giant cells, a hallmark of granulomatous reactions (Lemaire and Leduc, 2004). $\mathrm{P}_{2} \mathrm{X}_{7}$ receptors may be a relevant target for therapeutic intervention in lung hypersensitivity reactions associated with chronic inflammatory responses.

The need to support the failing lung (acute respiratory distress syndrome) with mechanical ventilation is potentially lifesaving, but, unfortunately, alveolar overdistension and pulmonary shear stress may cause lung injury (ventilator-induced lung injury), increasing bronchoalveolar lavage and leading to lung edema. It has been suggested that ventilator-induced lung injury may involve stretch-associated release of ATP from neuroepithelial cell bodies (Brouns et al., 2000, 2003; Rich et al., 2003) and may therefore be a therapeutic target for this condition.

The protective effect of ATP- $\mathrm{MgCl}_{2}$ in ischemia-reperfusion lung injury appears to require the presence of leukocytes (Chen et al., 2003).

\section{Musculoskeletal Diseases}

Several reports implicate purinergic signaling in bone development and remodeling (Bowler et al., 1999; Elfervig et al., 2001; Hoebertz et al., 2003; Costessi et al.,

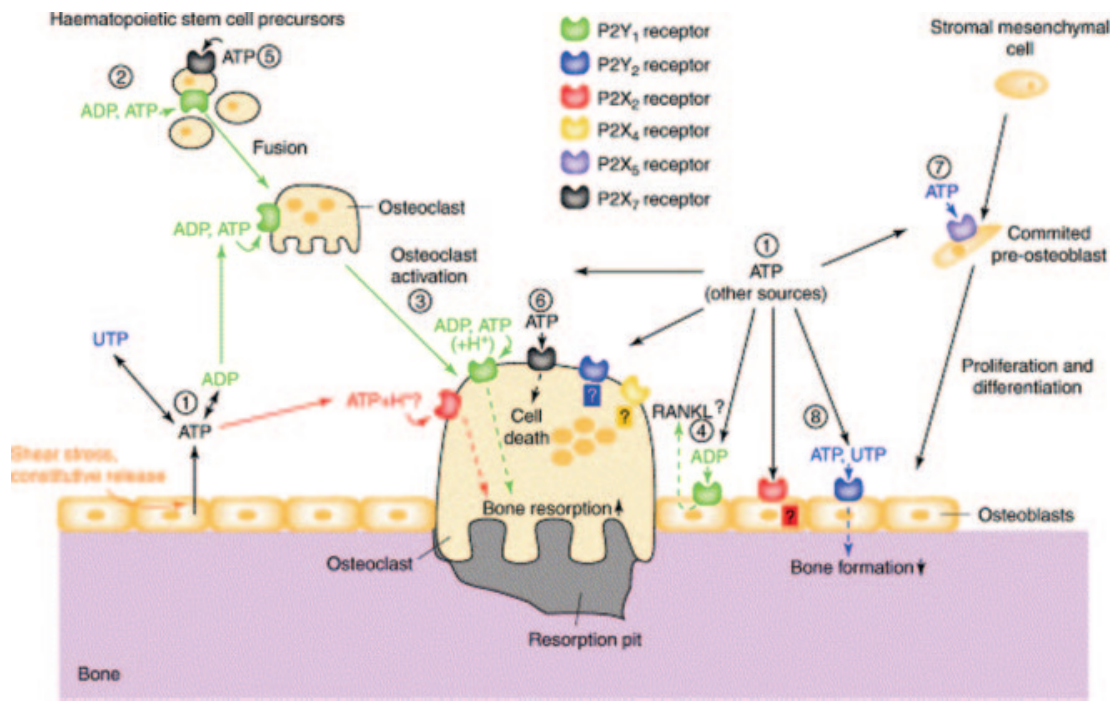

FIG. 3. Schematic diagram illustrating the potential roles played by extracellular nucleotides and P2 receptors in modulating bone cell function. ATP, released from osteoclasts (e.g., through shear stress or constitutively) or from other sources, can be degraded to ADP or converted into UTP via ecto-nucleotidases (1). All three nucleotides can act separately on specific P2 receptor subtypes, as indicated by the color coding. ATP is a universal agonist, whereas UTP is only active at the $\mathrm{P} 2 \mathrm{Y}_{2}$ receptor and ADP is only active at the $\mathrm{P} 2 \mathrm{Y}_{1}$ receptor. ADP via $\mathrm{P} 2 \mathrm{Y}_{1}$ receptors appears to stimulate both the formation (i.e., fusion) of osteoclasts from hematopoietic precursors and the resorptive activity of mature osteoclasts. For the latter, a synergistic action of ATP and protons has been proposed via the $\mathrm{P}_{2} \mathrm{X}_{2}$ receptor. ADP could also stimulate resorption indirectly through actions on osteoclasts, which in turn release proresorptive factors [e.g., receptor activator of nuclear factor- $\kappa \mathrm{B}$ ligand (RANKL)]. ATP at high concentrations might facilitate fusion of osteoclast progenitors through $\mathrm{P}_{2} \mathrm{X}_{7}$ receptor pore formation or induce cell death of mature osteoclasts via $\mathrm{P} 2 \mathrm{X}_{7}$ receptors. In osteoblasts, ATP, via P2X $\mathrm{X}_{5}$ receptors, might enhance proliferation and/or differentiation. By contrast, UTP, via P2Y 2 receptors, is a strong inhibitor of bone formation by osteoblasts. For some receptors (e.g., $\mathrm{P}_{2} \mathrm{X}_{4}$ and $\mathrm{P}_{2} \mathrm{Y}_{2}$ receptors on osteoclasts or $\mathrm{P} 2 \mathrm{X}_{2}$ receptors on osteoblasts), evidence for expression has been found, but their role is still unclear (question marks). Dashed lines indicate signaling events in the cell. Reprinted from Hoebertz et al. (2004), with permission from Elsevier. 
2005). P2X and P2Y receptors are present on osteoclasts, osteoblasts, and chondrocytes (Fig. 3). ATP, but not adenosine, stimulates the formation of osteoclasts and their resorptive actions in vitro and can inhibit osteoblast-dependent bone formation. The bisphosphonate clodronate, which is used in the treatment of Paget's disease and tumor-induced osteolysis, may act through osteoclast P2 receptors. Very low (nanomolar) concentrations of $\mathrm{ADP}$, acting through $\mathrm{P}_{2} \mathrm{Y}_{1}$ receptors, turn on osteoclast activity (Hoebertz et al., 2001).

In a recent study, deletion of the $\mathrm{P}_{2} \mathrm{X}_{7}$ receptor revealed its regulatory roles in bone formation and resorption (Ke et al., 2003). It reduces bone resorption by decreasing osteoclast survival (Korcok et al., 2004), and $\mathrm{P} \mathrm{X}_{7}$ receptors are expressed in a subpopulation of osteoblasts (Gartland et al., 2001). The multiple purinoceptors on bone and cartilage also represent potential targets for the development of novel therapeutics to inhibit bone resorption in diseases such as rheumatoid arthritis, osteoporosis, tumor-induced osteolysis, and periodontitis (Dixon and Sims, 2000; Komarova et al., 2001; Naemsch et al., 2001).

Nucleotide metabolism is tightly controlled in the cartilage extracellular matrix. Apart from modulating purinoceptor activation, ectoenzymes can regulate the levels of extracellular phosphate and pyrophosphate, the components involved in crystal deposition (Graff et al., 2003). Mechanical stimulation, which is critical for the maintenance of healthy articular cartilage, can influence the rate of nucleotide release and metabolism. The repair of fetal, but not adult, articular cartilage involves the intercellular transfer of ATP, an increase of $\left[\mathrm{Ca}^{2+}\right]_{\mathrm{i}}$, and expression of c-fos in cartilage (Kumahashi et al., 2004).

Tendinosis is a disorder characterized by acute or chronic pain and degenerative changes in the matrix. Mechanical loading induces ATP release from tendon cells and stimulates expression of IL- $1 \beta$, COX-2, and metalloproteinases as a negative feedback mechanism to limit activation of the injurious pathway. Attenuation of the feedback mechanism may result in the progression of tendinosis (Tsuzaki et al., 2003).

Ultrasound is often used to accelerate fracture healing. It has been shown recently that osteoblasts respond to ultrasound stimulation by increasing ATP release, which appears to mediate stimulation of osteoblast gene expression and cell proliferation (Hayton et al., 2005).

A role for purinergic signaling in rheumatic diseases has been considered for some time. Quinacrine (Atabrine), a drug that binds strongly to ATP, has been used for the treatment of patients with rheumatoid arthritis for many years (Wallace, 1989). One of its mechanisms of action is to decrease levels of prostaglandin $\mathrm{E}_{2}$ and COX-2, which are known to be produced following occupation of P2Y receptors by ATP (Needleman et al., 1974; Brambilla et al., 1999). The articular fluid removed from arthritic joints contains high levels of ATP (Ryan et al.,
1991). Purinergic regulation of bradykinin-induced plasma extravasation and adjuvant-induced arthritis has been reported (Green et al., 1991). ATP and UTP activate calcium-mobilizing $\mathrm{P}_{2} \mathrm{Y}_{2}$ or $\mathrm{P}_{2} \mathrm{Y}_{4}$ receptors and act synergistically with IL-1 to stimulate prostaglandin $\mathrm{E}_{2}$ release from human rheumatoid synovial cells (Loredo and Benton, 1998). When monoarthritis was induced by the injection of complete Freund's adjuvant into the unilateral temporomandibular joint of the rat, the pain produced was associated with an increase in $\mathrm{P}_{2} \mathrm{X}_{3}$ receptor-positive small neurons in the trigeminal ganglion (Shinoda et al., 2005). Relief of inflammatory pain by the $\mathrm{P}_{2} \mathrm{X}_{7}$ receptor antagonist, oxidized ATP, in arthritic rats has been reported (Dell'Antonio et al., 2002a,b). Spinal P1 receptor activation has been claimed to inhibit inflammation and joint destruction in rat adjuvant-induced arthritis, supporting the view that therapeutic strategies, which target the CNS, might be useful in arthritis (Boyle et al., 2002; Sorkin et al., 2003). Suppression of experimental zymosan-induced arthritis by intraperitoneal administration of adenosine has also been described (Baharav et al., 2002).

Lymphoblastoid cells isolated from patients with Duchenne muscular dystrophy are highly sensitive to stimulation by extracellular ATP (Ferrari et al., 1994). A recent study provides the first evidence for a role for purinergic signaling in muscle regeneration using the mdx mouse model of muscular dystrophy and raises the possibility of new therapeutic strategies for the treatment of muscle disease (Ryten et al., 2004). Pain related to the musculoskeletal system (myofascial pain) is very common, and ATP has been claimed to excite or sensitize myofascial nociceptors (Kennedy and Leff, 1995; BlandWard and Humphrey, 1997; Mork et al., 2003).

\section{Oncology}

The anticancer activity of adenine nucleotides was first described by Rapaport in 1983. Intraperitoneal injection of ATP into tumor-bearing mice resulted in significant anticancer activity against several fast-growing aggressive carcinomas (Agteresch et al., 2003). ATP inhibits the growth of murine colonic adenocarcinoma and human pancreatic carcinoma in mice as well as inhibiting the associated weight loss. In a recent comprehensive review about the use of ATP for the treatment of advanced cancer (Abraham et al., 2003), evidence was presented that 1) extracellular ATP inhibits the growth of a variety of human tumors, including prostate, breast, colon, liver, ovarian, colorectal, esophageal, and melanoma cancer cells, partly by mediating apoptotic cancer cell death; 2) ATP administration induces resistance of nonmalignant tissue to chemo- and radiation therapy, and 3) ATP has pronounced anticachexia effects, particularly in older patients, reducing weight loss, anorexia, and hormonal aberrations, largely via its ability to expand blood plasma ATP pools. It was concluded that 
preclinical data support utilization of ATP in the treatment of advanced cancers confirmed by phase I and II human trials indicating that ATP has a future place as a useful anticancer agent. The combination of ATP administration with other anticancer modalities is beginning to be explored.

Growth of prostate cancer cells in vitro is inhibited by up to $90 \%$ by ATP via P2 receptors, although it is not yet clear which subtype mediates this effect and whether it is a directly antiproliferative effect or a proapoptotic effect (Janssens and Boeynaems, 2001; Vanoverberghe et al., 2003; Calvert et al., 2004; Chen et al., 2004). Phase 1 clinical trials have shown that ATP infusion in patients with advanced cancer is feasible, but it is limited by chest tightness and dyspnea, probably due to conversion to adenosine (Agteresch et al., 1999). $\mathrm{P}_{2} \mathrm{Y}_{2}$ receptors are expressed in human colon carcinoma cells (Höpfner et al., 1998; Nylund et al., 2004).

A phase II trial has been carried out in patients with non-small-cell lung cancer, showing that intravenous ATP administered for $96 \mathrm{~h}$ at 4-week intervals reduced weight loss and improved muscle strength and quality of life (Agteresch et al., 2000; Dagnelie and Agteresch, 2004), as well as inducing cancer cell death (Agteresch et al., 2003). The combined use of ATP and the antitumor agent, etoposide, appears to improve the therapeutic index in human lung carcinoma (Hatta et al., 2004). Exposure of human lung cancer cells to 8-chloroadenosine, a potent therapeutic agent, induces mitotic catastrophe (Zhang et al., 2004a).

A combination of interferon- $\gamma$ and ATP is being explored for the treatment of acute myeloid leukemia. ATP induced irreversible damage of leukemic cells without injuring normal hemopoietic stem cells, and it was suggested that it could be useful for purging the residual leukemic cells in autologous bone marrow transplantation (Hatta et al., 1994). Extracellular ATP suppresses proliferation and induction of differentiation of human HL-60 leukemia cells, partly mediated by adenosine (after breakdown of ATP) and partly by ATP (Conigrave et al., 2000). $\mathrm{P} \mathrm{X}_{7}$ receptor expression in the evolutive form of chronic $\beta$-lymphocyte leukemia has been identified; ATP decreased proliferation of lymphocytes in this form of leukemia (Adinolfi et al., 2002). $\beta$-Cell chronic lymphocyte leukemia is unique in showing a 3-fold increased incidence in closely related family members compared with other lymphoproliferative diseases; a candidate gene for this familial incidence is the $\mathrm{P}_{2} \mathrm{X}_{7}$ gene (Dao-Ung et al., 2004). Expression of P2X $\mathrm{X}_{7}$ receptor mRNA is higher in most types of leukemia, although there is loss of $\mathrm{P} 2 \mathrm{X}_{7}$ receptor function (Zhang et al., 2004c).

Recent studies from our laboratory have analyzed the P2 receptor subtypes that contribute to ATP suppression of malignant melanomas (White et al., 2005a,b) in basal and squamous cell tumors (Greig et al., 2003b) and prostate and bladder cancers (Shabbir et al., 2003, 2004; Calvert et al., 2004). In general, $\mathrm{P} 2 \mathrm{Y}_{1}$ and $\mathrm{P} 2 \mathrm{Y}_{2}$ receptors mediate proliferation or antiproliferation, $\mathrm{P}_{2} \mathrm{X}_{5}$ receptors mediate cell differentiation, which in effect is antiproliferative, and $\mathrm{P}_{2} \mathrm{X}_{7}$ receptors mediate apoptotic cell death. ATP administration is particularly effective in treating bladder tumors when combined with the more commonly used anticancer drug mitomycin (Shabbir et al., 2004).

Intracarotid administration of ATP selectively increases blood flow in transplanted, malignant gliomas and suggests that this might enhance the delivery of anticancer agents to malignant brain tumors (Baba et al., 1989). $\mathrm{P}_{4} \mathrm{Y}_{4}$ receptors have been shown recently to participate in the commitment to differentiation and cell death of human neuroblastoma cells (Cavaliere et al., 2005).

For years, surgeons have washed the abdominal cavity with distilled water to lyse isolated cancer cells left after surgery. A recent study has shown that the hypotonicity produced by the water leads to cell swelling and release of ATP, which then acts on $\mathrm{P}_{2} \mathrm{X}_{7}$ receptors on cancer cells, leading to death (Selzner et al., 2004). 17 $\beta$ Estradiol has been shown to block the apoptosis induced by $\mathrm{P}_{2} \mathrm{X}_{7}$ receptor occupation of human cervical cancer cells (Wang et al., 2004b).

\section{Future Developments}

Although in its infancy, the clinical manipulation of purinergic signaling has begun. Several clinically relevant pharmacological interventions are already part of day-to-day practice. However, one of the main reasons that we do not yet have more purinergic therapies in our formularies is the current scarcity of receptor subtypespecific agonists and antagonists that are stable and effective in vivo. In addition to the development of selective agonists and antagonists for the different $\mathrm{P} 2$ receptor subtypes, therapeutic strategies are likely to include agents that control the expression of $\mathrm{P} 2$ receptors, inhibitors of extracellular breakdown of ATP, and enhancers or inhibitors of ATP transport. Investigating the interactions of purinergic signaling with other established signaling systems will also be very important.

\section{REFERENCES}

Abbracchio MP and Burnstock G (1994) Purinoceptors: are there families of $\mathrm{P}_{2 \mathrm{X}}$ and $\mathrm{P}_{2 \mathrm{Y}}$ purinoceptors? Pharmacol Ther 64:445-475.

Abbracchio MP and Burnstock G (1998) Purinergic signalling: pathophysiological roles. Jpn J Pharmacol 78:113-145.

Abraham EH, Salikhova AY, and Rapaport E (2003) ATP in the treatment of advanced cancer. Curr Top Membr 54:415-452.

Adair TH (2005) Growth regulation of the vascular system: an emerging role for adenosine. Am J Physiol 289:R283-R296.

Adinolfi E, Melchiorri L, Falzoni S, Chiozzi P, Morelli A, Tieghi A, Cuneo A, Castoldi G, Di Virgilio F, and Baricordi OR (2002) P2X $\mathrm{X}_{7}$ receptor expression in evolutive and indolent forms of chronic B lymphocytic leukemia. Blood 99:706-708.

Adriaensen D and Timmermans JP (2004) Purinergic signalling in the lung: important in asthma and COPD? Curr Opin Pharmacol 4:207-214.

Agboh KC, Webb TE, Evans RJ, and Ennion SJ (2004) Functional characterization of a P2X receptor from Schistosoma mansoni. J Biol Chem 279:41650-41657.

Agresti C, Meomartini ME, Amadio S, Ambrosini E, Volonté C, Aloisi F, and Visentin $\mathrm{S}$ (2005) ATP regulates oligodendrocyte progenitor migration, proliferation and differentiation: involvement of metabotropic P2 receptors. Brain Res Brain Res Rev 48:157-165.

Agteresch HJ, Dagnelie PC, van den Berg JWO, and Wilson JH (1999) Adenosine triphosphate: established and potential clinical applications. Drugs 58:211-232.

Agteresch HJ, Dagnelie PC, van der Gaast A, Stijnen T, and Wilson JH (2000)

Randomized clinical trial of adenosine 5 '-triphosphate in patients with advanced non-small-cell lung cancer. J Natl Cancer Inst 92:321-328.

Agteresch HJ, van Rooijen MHC, van den Berg JWO, Minderman-Voortman GJ, 
Wilson JHP, and Dagnelie PC (2003) Growth inhibition of lung cancer cells by adenosine 5-triphosphate. Drug Dev Res 60:196-203.

Alavi AM, Dubyak GR, and Burnstock G (2001) Immunohistochemical evidence for ATP receptors in human dental pulp. J Dental Res 80:476-483.

Almeida T, Rodrigues RJ, de Mendonca A, Ribeiro JA, and Cunha RA (2003) Purinergic $\mathrm{P} 2$ receptors trigger adenosine release leading to adenosine A2a receptor activation and facilitation of long-term potentiation in rat hippocampal slices. Neuroscience 122:111-121.

Andersson K-E (1997) Emptying against outflow obstruction-pharmacological aspects. Scand J Urol Nephrol Suppl 184:77-84.

Andersson K-E (2002) Overactive bladder-pharmacological aspects. Scand J Urol Nephrol Suppl 210:72-81.

Andersson K-E and Hedlund P (2002) Pharmacologic perspective on the physiology of the lower urinary tract. Urology 60:13-20.

Antunes VR, Bonagamba LG, and Machado BH (2005) Hemodynamic and respiratory responses to microinjection of ATP into the intermediate and caudal NTS of awake rats. Brain Res. 1032:85-93.

Aoki Y, Ohtori S, Takahashi K, Ino H, Ozawa T, Douya H, Chiba T, and Moriya H (2003) $\mathrm{P}_{2} \mathrm{X}_{3}$-immunoreactive primary sensory neurons innervating lumbar intervertebral disc in rats. Brain Res 989:214-220.

Arreola J and Melvin JE (2003) A novel chloride conductance activated by extracellular ATP in mouse parotid acinar cells. J Physiol 547:197-208.

Baba T, Fukui M, Sakata S, Tashima T, Takeshita I, Nakamura T, and Inoue T (1989) Selective enhancement of intratumoural blood flow in malignant gliomas: experimental study in rats by intracarotid administration of adenosine or adenosine triphosphate. Acta Neurochir (Wien) 101:66-74

Baharav E, Dubrosin A, Fishman P, Bar-Yehuda S, Halpren M, and Weinberger A (2002) Suppression of experimental zymosan-induced arthritis by intraperitoneal administration of adenosine. Drug Dev Res 57:182-186.

Bailey MA, Turner C, Hus-Citharel A, Marchetti J, Imbert-Teboul M, Milner P, Burnstock G, and Unwin R (2004) P2Y receptors present in the native and isolated rat glomerulus. Nephron Physiology 96:P79-P90.

Barclay J, Patel S, Dorn G, Wotherspoon G, Moffatt S, Eunson L, Abdel'al S, Natt F, Hall J, Winter J, et al. (2002) Functional downregulation of $\mathrm{P} 2 \mathrm{X}_{3}$ receptor subunit in rat sensory neurons reveals a significant role in chronic neuropathic and inflammatory pain. J Neurosci 22:8139-8147.

Beinart SC, Kolm P, Veledar E, Zhang Z, Mahoney EM, Bouin O, Gabriel S, Jackson J, Chen R, Caro J, et al. (2005) Long-term cost effectiveness of early and sustained dual oral antiplatelet therapy with clopidogrel given for up to one year after percutaneous coronary intervention: results from the clopidogrel for the reduction of events during observation (CREDO) trial. J Am Coll Cardiol 46:761-769.

Belhassen B, Fish R, Viskin S, Glick A, Glikson M, and Eldar M (2000) Adenosine$5^{\prime}$-triphosphate test for the noninvasive diagnosis of concealed accessory pathway. J Am Coll Cardiol 36:803-810.

Belhassen B and Pelleg A (1985) Adenosine triphosphate and adenosine: perspectives in the acute management of paroxysmal supraventricular tachycardia. Clin Cardiol 8:460-464.

Berry DA, Barden JA, Balcar VJ, and dos Remedios CG (1999) Increase in expression of $\mathrm{P}_{2}$ receptors in the atria of patients suffering from dilated cardiomyopathy. Electrophoresis 20:2059-2064.

Berti SL, Bonan CD, da Silva FL, Battastini AM, Sarkis JJ, and Wannmacher CM (2001) Phenylalanine and phenylpyruvate inhibit ATP diphosphohydrolase from rat brain cortex. Int J Dev Neurosci 19:649-653.

Bertrand PP (2003) ATP and sensory transduction in the enteric nervous system. Neuroscientist 9:243-260.

Bian X, Ren J, DeVries M, Schnegelsberg B, Cockayne DA, Ford AP, and Galligan JJ (2003) Peristalsis is impaired in the small intestine of mice lacking the $\mathrm{P}_{2} \mathrm{X}_{3}$ subunit. J Physiol 551:309-322.

Bianco F, Fumagalli M, Pravettoni E, D’Ambrosi N, Volonte C, Matteoli M, Abbracchio MP, and Verderio C (2005) Pathophysiological roles of extracellular nucleotides in glial cells: differential expression of purinergic receptors in resting and activated microglia. Brain Res Brain Res Rev 48:144-156.

Birder LA (2005) More than just a barrier: urothelium as a drug target for urinary bladder pain. Am J Physiol 289:F489-F495.

Birder LA, Ruan H-Z, Chopra B, Xiang Z, Barrick S, Buffington CA, Roppolo JR, Ford APDW, de Groat WC, and Burnstock G (2004) Alterations in P2X and P2Y purinergic receptor expression in urinary bladder from normal cats and cats with interstitial cystitis. Am J Physiol 287:F1084-F1091.

Birk AV, Leno E, Robertson HD, Bolotina VM, and Szeto HH (2003) Interaction between ATP and catecholamines in stimulation of platelet aggregation. Am J Physiol 284:H619-H625.

Blackburn MR (2003) Too much of a good thing: adenosine overload in adenosinedeaminase-deficient mice. Trends Pharmacol Sci 24:66-70.

Bland-Ward PA and Humphrey PPA (1997) Acute nociception mediated by hindpaw $\mathrm{P} 2 \mathrm{X}$ receptor activation in the rat. Br J Pharmacol 122:365-371.

Blaug S, Rymer J, Jalickee S, and Miller SS (2003) P2 purinoceptors regulate calcium-activated chloride and fluid transport in 31eg4 mammary epithelia. Am $J$ Physiol 284:C897-C909.

Bleehen T and Keele CA (1977) Observations on the algogenic actions of adenosine compounds on human blister base preparation. Pain 3:367-377.

Boeynaems JM, van Giezen H, Savi P, and Herbert JM (2005) P2Y receptor antagonists in thrombosis. Curr Opin Investig Drugs 6:275-282.

Boeynaems J-M, Robaye B, Janssens R, Suarez-Huerta N, and Communi D (2001) Overview of P2Y receptors as therapeutic targets. Drug Dev Res 52:187-189.

Bonan CD, Roesler R, Quevedo J, Battastini AM, Izquierdo I, and Sarkis JJ (1999) Effects of suramin on hippocampal apyrase activity and inhibitory avoidance learning of rats. Pharmacol Biochem Behav 63:153-158.

Borna C, Wang L, Gudbjartsson T, Karlsson L, Jern S, Malmsjo M, and Erlinge D (2003) Contractions in human coronary bypass vessels stimulated by extracellular nucleotides. Ann Thorac Surg 76:50-57.

Boselli C, Govoni S, Condino AM, and D’Agostino G (2001) Bladder instability: a re-appraisal of classical experimental approaches and development of new therapeutic strategies. J Auton Pharmacol 21:219-229.

Bowler WB, Dixon C.J, Halleux C, Maier R, Bilbe G, Fraser WD, Gallagher JA, and Hipskind RA (1999) Signaling in human osteoblasts by extracellular nucleotides. Their weak induction of the c-fos proto-oncogene via $\mathrm{Ca}^{2+}$ mobilization is strongly potentiated by a parathyroid hormone/cAMP-dependent protein kinase pathway independently of mitogen-activated protein kinase. J Biol Chem 274:14315-14324.

Bowser DN and Khakh BS (2004) ATP excites interneurons and astrocytes to increase synaptic inhibition in neuronal networks. J Neurosci 24:8606-8620.

Boyle DL, Moore J, Yang L, Sorkin LS, and Firestein GS (2002) Spinal adenosine receptor activation inhibits inflammation and joint destruction in rat adjuvantinduced arthritis. Arthritis Rheum 46:3076-3082.

Bradbury EJ, Burnstock G, and McMahon SB (1998) The expression of P2X $\mathrm{X}_{3}$ purinoceptors in sensory neurons: effects of axotomy and glial-derived neurotrophic factor. Mol Cell Neurosci 12:256-268.

Brambilla R, Burnstock G, Bonazzi A, Ceruti S, Cattabeni F, and Abbracchio MP (1999) Cyclooxygenase-2 mediates P2Y receptor-induced reactive astrogliosis: special report. Br J Pharmacol 126:563-567.

Broadley KJ (2000) Drugs modulating adenosine receptors as potential therapeutic agents for cardiovascular diseases. Exp Opin Ther Patents 10:1169-1692.

Brockhaus J, Dressel D, Herold S, and Deitmer JW (2004) Purinergic modulation of synaptic input to Purkinje neurons in rat cerebellar brain slices. Eur J Neurosci 19:2221-2230.

Brook MM, Fineman JR, Bolinger AM, Wong AF, Heymann MA, and Soifer SJ (1994) Use of ATP- $\mathrm{MgCl}_{2}$ in the evaluation and treatment of children with pulmonary hypertension secondary to congenital heart defects. Circulation 90:1287-1293.

Brouns I, Adriaensen DD, Burnstock G, and Timmermans J-P (2000) Intraepithelial vagal sensory nerve terminals in rat pulmonary neuroepithelial bodies express $\mathrm{P}_{3} \mathrm{X}_{3}$ receptors. Am J Respir Cell Mol Biol 23:52-61.

Brouns I, Van Genechten J, Hayashi H, Gajda M, Gomi T, Burnstock G, Timmermans J-P, and Adriaensen D (2003) Dual sensory innervation of pulmonary neuroepithelial bodies. Am J Respir Cell Mol Biol 28:275-285.

Bruno AN, Pochmann D, Riacachenevsky FK, Bonan CD, Barreto-Chaves MLM, and Sarkis JJF (2005a) 5'-Nucleotidase activity is altered by hypo-hyperthyroidism in platelets from adult rats. Platelets 16:25-30.

Bruno AN, Riacachenevsky FK, Pochmann D, Bonan CD, Battastini AMO, BarretoChaves MLM, and Sarkis JJF (2005b) Hypothyroidism changes adenine nucleotide hydrolysis in synaptosomes from hippocampus and cerebral cortex of rats in different phases of development. Int J Dev Neurosci 23:37-44.

Bucheimer RE and Linden J (2004) Purinergic regulation of epithelial transport. J Physiol 555:311-321.

Burgard EC, Niforatos W, van Biesen T, Lynch KJ, Kage KL, Touma E, Kowaluk EA and Jarvis MF (2000) Competitive antagonism of recombinant $\mathrm{P} 2 \mathrm{X}_{2 / 3}$ receptors by $2^{\prime}, 3^{\prime}-O$-(2,4,6-trinitrophenyl) adenosine $5^{\prime}$-triphosphate (TNP-ATP). Mol Pharmacol 58:1502-1510.

Burnstock G (1972) Purinergic nerves. Pharmacol Rev 24:509-581.

Burnstock G (1978) A basis for distinguishing two types of purinergic receptor, in Cell Membrane Receptors for Drugs and Hormones: A Multidisciplinary Approach (Straub RW and Bolis L eds) pp 107-118, Raven Press, New York.

Burnstock G (1981) Pathophysiology of migraine: a new hypothesis. Lancet i:13971399.

Burnstock G (1989) The role of adenosine triphosphate in migraine. Biomed Pharmacother 43:727-736.

Burnstock G (1996a) Purinoceptors: ontogeny and phylogeny. Drug Dev Res 39:204242

Burnstock G (1996b) A unifying purinergic hypothesis for the initiation of pain Lancet 347:1604-1605.

Burnstock G (1999) Release of vasoactive substances from endothelial cells by shear stress and purinergic mechanosensory transduction. $J$ Anat 194:335-342.

Burnstock G (2001a) Purinergic signalling in development, in Handbook of Experimental Pharmacology, Purinergic and Pyrimidinergic Signalling I-Molecular, Nervous and Urinogenitary System Function (Abbracchio MP and Williams M eds) vol 151, part I, pp 89-127, Springer-Verlag, Berlin.

Burnstock G (2001b) Purinergic signalling in gut, in Handbook of Experimental Pharmacology, Purinergic and Pyrimidinergic Signalling II-Cardiovascular, Re spiratory, Immune, Metabolic and Gastrointestinal Tract Function (Abbracchio MP and Williams M eds), vol 151, part II, pp 141-238, Springer-Verlag, Berlin.

Burnstock G (2001c) Purine-mediated signalling in pain and visceral perception. Trends Pharmacol Sci 22:182-188.

Burnstock G (2001d) Overview of P2 receptors: possible functions in immune cells. Drug Dev Res 53:53-59.

Burnstock G (2001e) Purinergic signalling in lower urinary tract, in Handbook of Experimental Pharmacology, Purinergic and Pyrimidinergic Signalling I-Molec ular, Nervous and Urinogenitary System Function (Abbracchio MP and Williams M eds) vol 151, part I, pp 423-515, Springer-Verlag, Berlin.

Burnstock G (2002a) Purinergic signalling and vascular cell proliferation and death Arterioscler Thromb Vasc Biol 22:364-373.

Burnstock G (2002b) Potential therapeutic targets in the rapidly expanding field of purinergic signalling. Clin Med 2:45-53.

Burnstock G (2003a) Introduction: ATP and its metabolites as potent extracellular agents. Curr Top Membr 54:1-27.

Burnstock G (2003b) Purinergic receptors in the nervous system. Curr Top Membr 54:307-368.

Burnstock G (2004) Cotransmission. Curr Opin Pharmacol 4:47-52.

Burnstock G, Campbell G, Satchell D, and Smythe A (1970) Evidence that adenosine triphosphate or a related nucleotide is the transmitter substance released by non-adrenergic inhibitory nerves in the gut. $\mathrm{Br} J$ Pharmacol 40:668-688.

Burnstock G and Kennedy C (1985) Is there a basis for distinguishing two types of $\mathrm{P}_{2}$-purinoceptor? Gen Pharmacol 16:433-440.

Burnstock G and Knight GE (2004) Cellular distribution and functions of P2 receptor subtypes in different systems. Int Rev Cytol 240:31-304. 
Burnstock G and Lavin S (2002) Interstitial cells of cajal and purinergic signalling. Auton Neurosci 97:68-72.

Burnstock G and Ralevic V (1994) New insights into the local regulation of blood flow by perivascular nerves and endothelium. Br J Plast Surg 47:527-543.

Burnstock G and Williams M (2000) P2 purinergic receptors: modulation of cell function and therapeutic potential. J Pharmacol Exp Ther 295:862-869.

Burnstock G and Wood JN (1996) Purinergic receptors: their role in nociception and primary afferent neurotransmission. Curr Opin Neurobiol 6:526-532.

Burrell HE, Bowler WB, Gallagher JA, and Sharpe GR (2003) Human keratinocytes express multiple $\mathrm{P} 2 \mathrm{Y}$-receptors: evidence for functional $\mathrm{P}_{1} \mathrm{Y}_{1}, \mathrm{P}_{2} \mathrm{Y}_{2}$ and $\mathrm{P} 2 \mathrm{Y}_{4}$ receptors. J Investig Dermatol 120:440-447.

Cain DM, Wacnik PW, Eikmeier L, Beitz A, Wilcox GL, and Simone DA (2001) Functional interactions between tumor and peripheral nerve in a model of cancer pain in the mouse. Pain Med 2:15-23.

Cakir E, Baykal S, Karahan SC, Kuzeyli K, and Uydu H (2003) Acute phase effects of ATP- $\mathrm{MgCl}_{2}$ on experimental spinal cord injury. Neurosurg Rev 26:67-70.

Calvert RC, Shabbir M, Thompson CS, Mikhailidis DP, Morgan R, and Burnstock G (2004) Immunocytochemical and pharmacological characterisation of P2purinoceptor-mediated cell growth and death in PC-3 hormone refractory prostate cancer cells. Anticancer Research 24:2853-2859.

CAPRIE Steering Committee (2001) A randomised, blinded, trial of clopidogrel versus aspirin in patients at risk of ischaemic events. Lancet 348:1329-1339.

Cario-Toumaniantz C, Loirand G, Ladoux A, and Pacaud P (1998) P2X 7 receptor activation-induced contraction and lysis in human saphenous vein smooth muscle. Circ Res 83:196-203.

Cattaneo M, Lecchi A, Ohno M, Joshi BV, Besada P, Tchilinbon S, Lombardi R Bischofberger N, Harden TK, and Jacobson KA (2004) Antiaggregatory activity in human platelets of potent antagonists of the $\mathrm{P}_{2} \mathrm{Y}_{1}$ receptor. Biochem Pharmacol 68:1995-2002.

Cavaliere F, Florenzano F, Amadio S, Fusco FR, Viscomi MT, D'Ambrosi N, Vacca F, Sancesario G, Bernardi G, Molinari M, et al. (2003) Up-regulation of P2X $\mathrm{X}_{2}, \mathrm{P}_{2} \mathrm{X}_{4}$ receptor and ischemic cell death: prevention by P2 antagonists. Neuroscience 120:85-98.

Cavaliere F, Nestola V, Amadio S, D'Ambrosi N, Angelini DF, Sancesario G, Bernardi G, and Volonte C (2005) The metabotropic $\mathrm{P}_{2} \mathrm{Y}_{4}$ receptor participates in the commitment to differentiation and cell death of human neuroblastoma SH-SY5Y cells. Neurobiol Dis 18:100-109.

Chen CC, Akopian AN, Sivilotti L, Colquhoun D, Burnstock G, and Wood JN (1995) A P2X purinoceptor expressed by a subset of sensory neurons. Nature (Lond) 377:428-431.

Chen L, He H-Y, Li H-M, Zheng J, Heng W-J, You J-F and Fang W-G (2004) ERK1/2 and p38 pathways are required for P2Y receptor-mediated prostate cancer invasion. Cancer Letts 215:239-247.

Chen WC and Chen CC (1998) ATP-induced arachidonic acid release in cultured astrocytes is mediated by $\mathrm{Gi}$ protein coupled $\mathrm{P}_{2} \mathrm{Y}_{1}$ and $\mathrm{P}_{2} \mathrm{Y}_{2}$ receptors. Glic 22:360-370.

Chen WT, Huang WH, Wang D, Yu FC, Chi YC, Wu JC, Wu K, Perng WC, Wu CP, and Yan $\mathrm{HC}$ (2003) The protective effect of adenosine triphosphate- $\mathrm{MgCl}_{2}$ on ischemia-reperfusion lung injury is leukocyte dependent. J Biomed Sci 10:725730 .

Chessell IP, Hatcher JP, Bountra C, Michel AD, Hughes JP, Green P, Egerton J, Murfin M, Richardson J, Peck WL, et al. (2005) Disruption of the P2X purinoceptor gene abolishes chronic inflammatory and neuropathic pain. Pain 114:386396

Chess-Williams R (2004) Potential therapeutic targets for the treatment of detrusor overactivity. Expert Opin Ther Targets 8:95-106.

Chizh BA and Illes P (2000) P2X receptors and nociception. Pharmacol Rev 53:553568

Choi HB, Hong SH, Ryu JK, Kim SU, and McLarnon JG (2003) Differential activation of subtype purinergic receptors modulates $\mathrm{Ca}^{2+}$ mobilization and COX-2 in human microglia. Glia 43:95-103.

Chorna NE, Santiago-Perez LI, Erb L, Seye CI, Neary JT, Sun GY, Weisman GA, and Gonzalez FA (2004) $\mathrm{P}_{2} \mathrm{Y}_{2}$ receptors activate neuroprotective mechanisms in astrocytic cells. J Neurochem 91:119-132.

Churchill PC and Ellis VR (1993) Purinergic P2y receptors stimulate renin secretion by rat renal cortical slices. J Pharmacol Exp Ther 266:160-163.

Cockayne DA, Hamilton SG, Zhu Q-M, Dunn PM, Zhong Y, Novakovic S, Malmberg AB, Cain G, Berson A, Kassotakis L, et al. (2000) Urinary bladder hyporeflexia and reduced pain-related behaviour in $\mathrm{P}_{2} \mathrm{X}_{3}$-deficient mice. Nature (Lond) 407:1011-1015

Collier HO, James GWL, and Schneider C (1966) Antagonism by aspirin and fenamates of bronchoconstriction and nociception induced by adenosine-5' triphosphate. Nature (Lond) 212:411-412.

Collo G, North RA, Kawashima E, Merlo-Pich E, Neidhart S, Surprenant A, and Buell $\mathrm{G}$ (1996) Cloning of $\mathrm{P} 2 \mathrm{X}_{5}$ and $\mathrm{P} 2 \mathrm{X}_{6}$ receptors and the distribution and properties of an extended family of ATP-gated ion channels. J Neurosci 16:2495-2507.

Colomar A and Amedee T (2001) ATP stimulation of $\mathrm{P}_{2} \mathrm{X}_{7}$ receptors activates three different ionic conductances on cultured mouse Schwann cells. Eur J Neurosci 14:927-936.

Conigrave $\mathrm{AD}$, van der Weyden L, Holt L, Jiang L, Wilson P, Christopherson RI, and Morris MB (2000) Extracellular ATP-dependent suppression of proliferation and induction of differentiation of human HL-60 leukemia cells by distinct mechanisms. Biochem Pharmacol 60:1585-1591.

Cook PW, Ashton NM, and Pittelkow MR (1995) Adenosine and adenine nucleotides inhibit the autonomous and epidermal growth factor-mediated proliferation of cultured human keratinocytes. J Investig Dermatol 104:976-981.

Cooke HJ, Wunderlich J, and Christofi FL (2003) "The force be with you": ATP in gut mechanosensory transduction. News Physiol Sci 18:43-49.

Costessi A, Pines A, D’Andrea P, Romanello M, Damante G, Cesaratto L, Quadrifoglio F, Moro L, and Tell G (2005) Extracellular nucleotides activate Runx2 in the osteoblast-like HOBIT cell line: a possible molecular link between mechanical stress and osteoblasts' response. Bone 36:418-432.
Coutinho-Silva R, Parsons M, Robson T, and Burnstock G (2001) Changes in expression of $\mathrm{P} 2$ receptors in rat and mouse pancreas during development and aging. Cell Tissue Res 306:373-383.

Coutinho-Silva R, Parsons M, Robson T, Lincoln J, and Burnstock G (2003) P2X and $\mathrm{P} 2 \mathrm{Y}$ purinoceptor expression in pancreas from streptozotocin-diabetic rats. $\mathrm{Mo}$ Cell Endocrinol 204:141-154.

Dagnelie PC and Agteresch HJ (2004) Promising effects of adenosine triphosphate infusion on nutritional status and quality of life in advanced non-small-cell lung cancer: a randomized clinical trial. Drug Dev Res 59:146-151.

Dang K, Bielfeldt K, Lamb K, and Gebhart GF (2005) Gastric ulcers evoke hyper excitability and enhance $\mathrm{P} 2 \mathrm{X}$ receptor function in rat gastric sensory neurons. $J$ Neurophysiol 93:3112-3119.

Dao-Ung LP, Fuller SJ, Sluyter R, SkarRatt KK, Thunberg U, Tobin G, Byth K, Ban M, Rosenquist R, Stewart GJ, et al. (2004) Association of the $1513 \mathrm{C}$ polymorphism in the $\mathrm{P}_{2} \mathrm{X}_{7}$ gene with familial forms of chronic lymphocytic leukaemia. $\mathrm{Br} J$ Haematol 125:815-817.

Davalos D, Grutzendler J, Yang G, Kim JV, Zuo Y, Jung S, Littman DR, Dustin ML, and Gan WB (2005) ATP mediates rapid microglial response to local brain injury in vivo. Nat Neurosci 8:752-758.

Davis IC, Sullender WM, Hickman-Davis JM, Lindsey JR, and Matalon S (2004) Nucleotide-mediated inhibition of alveolar fluid clearance in BALB/c mice after respiratory syncytial virus infection. Am J Physiol 286:L112-L120.

De Paula PM, Antunes VR, Bonagamba LG, and Machado BH (2004) Cardiovascular responses to microinjection of ATP into the nucleus tractus solitarii of awake rats. Am J Physiol 287:R1164-R1171.

Dell'Antonio G, Quattrini A, Dal Cin E, Fulgenzi A, and Ferrero ME (2002a) Relief of inflammatory pain in rats by local use of the selective $\mathrm{P}_{2} \mathrm{X}_{7}$ ATP receptor inhibitor, oxidized ATP. Arthritis Rheum 46:3378-3385.

Dell'Antonio G, Quattrini A, Dal Cin E, Fulgenzi A, and Ferrero ME (2002b) Antinociceptive effect of a new $\mathrm{P}_{27} / \mathrm{P} \mathrm{X}_{7}$ antagonist, oxidized ATP, in arthritic rats. Neurosci Lett 327:87-90.

Denda M, Inoue K, Fuziwara S, and Denda S (2002) P2X purinergic receptor antagonist accelerates skin barrier repair and prevents epidermal hyperplasia induced by skin barrier disruption. J Investig Dermatol 119:1034-1040.

Dhalla AK, Shryock JC, Shreeniwas R, and Belardinelli L (2003) Pharmacology and therapeutic applications of A1 adenosine receptor ligands. Curr Top Med Chem 3:369-385.

Di Virgilio F, Chiozzi P, Ferrari D, Falzoni S, Sanz JM, Morelli A, Torboli M, Bolognesi G, and Baricordi OR (2001) Nucleotide receptors: an emerging family of regulatory molecules in blood cells. Blood 97:587-600.

Di Virgilio F, Falzoni S, Mutini C, Sanz JM, and Chiozzi P (1998) Purinergic P2X receptor: a pivotal role in inflammation and immunomodulation. Drug Dev Res 45:207-213.

Di Virgilio F and Solini A (2002) P2 receptors: new potential players in atherosclerosis. Br J Pharmacol 135:831-842.

Dixon CJ, Bowler WB, Littlewood-Evans A, Dillon JP, Bilbe G, Sharpe GR, and Gallagher JA (1999) Regulation of epidermal homeostasis through $\mathrm{P}_{2} \mathrm{Y}_{2}$ receptors. Br J Pharmacol 127:1680-1686.

Dixon SJ and Sims SM (2000) P2 purinergic receptors on osteoblasts and osteoclasts: potential targets for drug development. Drug Dev Res 49:187-200.

Dorn G, Patel S, Wotherspoon G, Hemmings-Mieszczak M, Barclay J, Natt FJ, Martin P, Bevan S, Fox A, Ganju P, et al. (2004) SiRNA relieves chronic neuropathic pain. Nucleic Acids Res 32:e49.

Dranoff JA, Ogawa M, Kruglov EA, Gaca MD, Sevigny J, Robson SC, and Wells RG (2004) Expression of P2Y nucleotide receptors and ectonucleotidases in quiescent and activated rat hepatic stellate cells. Am J Physiol 287:G417-G424.

Drury AN and Szent-Györgyi A (1929) The physiological activity of adenine com pounds with special reference to their action upon the mammalian heart. J Physiol (Lond) 68:213-237.

Dubyak GR and El Moatassim C (1993) Signal transduction via P2-purinergic receptors for extracellular ATP and other nucleotides. Am J Physiol 265:C577-C606.

Duhant X, Schandene L, Bruyns C, Gonzalez NS, Goldman M, Boeynaems JM, and Communi D (2002) Extracellular adenine nucleotides inhibit the activation of human $\mathrm{CD}^{+}{ }^{+} \mathrm{T}$ lymphocytes. J Immunol 169:15-21.

Dunn PM (2000) Fertility: purinergic receptors and the male contraceptive pill. Curr Biol 10:R305-R307.

Dunn PM, Zhong Y, and Burnstock G (2001) P2X receptors in peripheral neurones. Prog Neurobiol 65:107-134.

Edwards FA, Gibb AJ, and Colquhoun D (1992) ATP receptor-mediated synaptic currents in the central nervous system. Nature (Lond) 359:144-147.

Elfervig MK, Graff RD, Lee GM, Kelley SS, Sood A, and Banes AJ (2001) ATP induces $\mathrm{Ca}^{2+}$ signaling in human chondrons cultured in three-dimensional agarose films. Osteoarthritis Cartilage 9:518-526.

Eltzschig HK, Ibla JC, Furuta GT, Leonard MO, Jacobson KA, Enjyoji K, Robson SC, and Colgan SP (2003) Coordinated adenine nucleotide phosphohydrolysis and nucleoside signaling in posthypoxic endothelium: role of ectonucleotidases and adenosine A2B receptors. J Exp Med 198:783-796.

Enjyoji K, Sevigny J, Lin Y, Frenette PS, Christie PD, Esch JS 2nd, Imai M, Edelberg JM, Rayburn H, Lech M, et al. (1999) Targeted disruption of cd39/ATP diphosphohydrolase results in disordered hemostasis and thromboregulation. Nat Med 5:1010-1017.

Erlinge D, Hou M, Webb TE, Barnard EA, and Moller S (1998) Phenotype changes of the vascular smooth muscle cell regulate $\mathrm{P} 2$ receptor expression as measured by quantitative RT-PCR. Biochem Biophys Res Commun 248:864-870.

Essien EM and White AG (1998) Elevated plasma adenosine triphosphate (ATP concentration in human acute malaria infection. Thromb Haemost 80:867-868.

Evans RJ, Derkach V, and Surprenant A (1992) ATP mediates fast synaptic transmission in mammalian neurons. Nature (Lond) 357:503-505.

Exley C and Korchazhkina OV (2001) Promotion of formation of amyloid fibrils by aluminium adenosine triphosphate (AlATP). J Inorg Biochem 84:215-224.

Facer P, Knowles CH, Tam PK, Ford AP, Dyer N, Baecker PA, and Anand P (2001) 
Novel capsaicin (VR1) and purinergic $\left(\mathrm{P}_{2} \mathrm{X}_{3}\right)$ receptors in Hirschsprung's intestine. J Pediatr Surg 36:1679-1684.

Fairbairn IP, Stober CB, Kumararatne DS, and Lammas DA (2001) ATP-mediated killing of intracellular mycobacteria by macrophages is a $\mathrm{P} 2 \mathrm{X}_{7}$-dependent process inducing bacterial death by phagosome-lysosome fusion. J Immunol 167:33003307.

Feng C, Mery AG, Beller EM, Favot C, and Boyce JA (2004) Adenine nucleotides inhibit cytokine generation by human mast cells through a $\mathrm{G}_{\mathrm{s}}$-coupled receptor. $J$ Immunol 173:7539-7547.

Feoktistov I and Biaggioni I (1996) Role of adenosine in asthma. Drug Dev Res 39:333-336.

Feranchac AP and Fitz JG (2003) Purinergic receptors and hepatobiliary function. Curr Top Membr 54:395-414.

Ferguson DR and Christopher N (1996) Urinary bladder function and drug development. Trends Pharmacol Sci 17:161-165.

Ferguson DR, Kennedy I, and Christopher N (1997) ATP is released from rabbit urinary bladder epithelial cells by hydrostatic pressure changes-a possible sensory mechanism? J Physiol (Lond) 505:503-511.

Ferrari D, Munerati M, Melchiorri L, Hanau S, Di Virgillio F, and Baricordi OR (1994) Responses to extracellular ATP of lymphoblastoid cell lines from Duchenne muscular dystrophy patients. Am J Physiol 267:C886-C892.

Fields RD and Stevens B (2000) ATP: an extracellular signaling molecule between neurons and glia. Trends Neurosci 23:625-633.

Fields RD and Stevens-Graham B (2002) New insights into neuron-glia communication. Science (Wash DC) 298:556-562.

Flier JS (1995) The adipocyte: storage depot or node on the energy information superhighway? Cell 80:15-18.

Florenzano F, Viscomi MT, Cavaliere F, Volonte C, and Molinari M (2002) Cerebellar lesion up-regulates $\mathrm{P} 2 \mathrm{X}_{1}$ and $\mathrm{P} 2 \mathrm{X}_{2}$ purinergic receptors in precerebellar nuclei. Neuroscience 115:425-434.

Fontana P, Dupont A, Gandrille S, Bachelot-Loza C, Reny JL, Aiach M, and Gaussem P (2003) Adenosine diphosphate-induced platelet aggregation is associated with $\mathrm{P}_{2} \mathrm{Y}_{12}$ gene sequence variations in healthy subjects. Circulation 108:989995.

Fozard JR and McCarthy C (2002) Adenosine receptor ligands as potential therapeutics in asthma. Curr Opin Investig Drugs 3:69-77.

Fredholm BB (1981) Adenosine and lipolysis. Int J Obes 5:643-649.

Fredholm BB, Abbracchio MP, Burnstock G, Daly JW, Harden TK, Jacobson KA, Leff $\mathrm{P}$, and Williams M (1994) Nomenclature and classification of purinoceptors. Phar macol Rev 46:143-156.

Fredholm BB, Chen JF, Masino SA, and Vaugeois JM (2005) Actions of adenosine at its receptors in the CNS: insights from knockouts and drugs. Ann Rev Pharmacol Toxicol 45:385-412.

Fredholm BB, Cunha RA, and Svenningsson P (2002) Pharmacology of adenosine $\mathrm{A}_{2 \mathrm{~A}}$ receptors and therapeutic applications. Curr Topics Med Chem 3:413-426.

Fry CH, Ikeda Y, Harvey R, Wu C, and Sui GP (2004) Control of bladder function by peripheral nerves: avenues for novel drug targets. Urology 63:24-31.

Fujii S, Kato H, and Kuroda Y (1999) Extracellular adenosine 5'-triphosphate plus activation of glutamatergic receptors induces long-term potentiation in CA1 neurons of guinea pig hippocampal slices. Neurosci Lett 276:21-24.

Fujii S, Kato H, and Kuroda Y (2002) Cooperativity between extracellular adenosine $5^{\prime}$-triphosphate and activation of $N$-methyl-D-aspartate receptors in long-term potentiation induction in hippocampal CA1 neurons. Neuroscience 113:617-628.

Funk GD, Kanjhan R, Walsh C, Lipski J, Comer AM, Parkis MA, and Housley GD (1997) P2 receptor excitation of rodent hypoglossal motoneuron activity in vitro and in vivo: a molecular physiological analysis. J Neurosci 17:6325-6337.

Gaba SJ, Bourgouin-Karaouni D, Dujols P, Michel FB, and Prefaut C (1986) Effects of adenosine triphosphate on pulmonary circulation in chronic obstructive pulmonary disease. ATP: a pulmonary vasoregulator? Am Rev Respir Dis 134:1140 1144.

Gachet C (2001) ADP receptors of platelets and their inhibition. Thromb Haemost 86:222-232.

Gale JE, Piazza V, Ciubotaru CD, and Mammano F (2004) A mechanism for sensing noise damage in the inner ear. Curr Biol 14:526-529.

Galligan JJ (2002) Pharmacology of synaptic transmission in the enteric nervous system. Curr Opin Pharmacol 2:623-629.

Galligan JJ (2004) Enteric P2X receptors as potential targets for drug treatment of the irritable bowel syndrome. Br J Pharmacol 141:1294-1302.

Gartland A, Hipskind RA, Gallagher JA, and Bowler WB (2001) Expression of a P2X receptor by a subpopulation of human osteoblasts. J Bone Miner Res 16:846-856

Gayle S and Burnstock G (2005) Immunolocalisation of P2X and P2Y nucleotide receptors in the rat nasal mucosa. Cell Tissue Res 319:27-36.

Gendron FP, Chalimoniuk M, Strosznajder J, Shen S, Gonzalez FA, Weisman GA, and Sun GY (2003) P2X $\mathrm{X}_{7}$ nucleotide receptor activation enhances IFN $\gamma$-induced type II nitric oxide synthase activity in BV-2 microglial cells. J Neurochem 87: $344-352$.

Gerevich Z, Borvendeg SJ, Schroder W, Franke H, Wirkner K, Norenberg W, Furst S, Gillen C, and Illes P (2004) Inhibition of N-type voltage-activated calcium channels in rat dorsal root ganglion neurons by $\mathrm{P} 2 \mathrm{Y}$ receptors is a possible mechanism of ADP-induced analgesia. J Neurosci 24:797-807.

Giaroni C, Knight GE, Ruan H-Z, Glass R, Bardini M, Lecchini S, Frigo G, and Burnstock G (2002) P2 receptors in the murine gastrointestinal tract. Neuropharmacology 43:1313-1323.

Gilchrist LS, Cain DM, Harding-Rose C, Kov AN, Wendelschafer-Crabb G, Kennedy WR, and Simone DA (2005) Re-organization of $\mathrm{P}_{2} \mathrm{X}_{3}$ receptor localization on epidermal nerve fibers in a murine model of cancer pain. Brain Res 1044:197-205.

Glass R, Bardini M, Robson T, and Burnstock G (2001) Expression of nucleotide P2X receptor subtypes during spermatogenesis in the adult rat testis. Cells Tissues Org 169:377-387.

Göçmen C, Giesselman B, and de Groat WC (2005) Effect of neocuproine, a copper(I) chelator, on rat bladder function. J Pharmacol Exp Ther 312:1138-1143.
Goepfert C, Sundberg C, Sevigny J, Enjyoji K, Hoshi T, Csizmadia E, and Robson S (2001) Disordered cellular migration and angiogenesis in cd39-null mice. Circulation 104:3109-3115.

Gorodeski GI (2002) Regulation of transcervical permeability by two distinct P2 purinergic receptor mechanisms. Am J Physiol 282:C75-C83.

Gourine AV, Atkinson L, Deuchars J, and Spyer KM (2003) Purinergic signalling in the medullary mechanisms of respiratory control in the rat: respiratory neurones express the $\mathrm{P}_{2} \mathrm{X}_{2}$ receptor subunit. J Physiol 552:197-211.

Gourine AV, Dale N, Gourine VN, and Spyer KM (2004) Fever in systemic inflammation: roles of purines. Front Biosci 9:1011-1022.

Gourine AV, Melenchuk EV, Poputnikov DM, Gourine VN, and Spyer KM (2002) Involvement of purinergic signalling in central mechanisms of body temperature regulation in rats. $\mathrm{Br}$ J Pharmacol 135:2047-2055.

Gourine AV and Spyer KM (2003) Chemosensitivity of medullary respiratory neurones: a role for ionotropic $\mathrm{P} 2 \mathrm{x}$ and GABA receptors, in Chemoreception (Gonzalez G, Prabhakar JM, Pequignot JM, Nurse CA and Dalmaz Y eds) pp 375-387, Kluwer Academic/Plenum Publishers, New York.

Graff RD, Picher M, and Lee GM (2003) Extracellular nucleotides, cartilage stress and calcium crystal formation. Curr Opin Rheumatol 15:315-320.

Granstein RD, Ding W, Huang J, Holzer A, Gallo RL, Di Nardo A, and Wagner JA (2005) Augmentation of cutaneous immune responses by ATP $\gamma \mathrm{S}$ : purinergic agonists define a novel class of immunologic adjuvants. J Immunol 174:7725-7731.

Green PG, Basbaum AI, Helms C, and Levine JD (1991) Purinergic regulation of bradykinin-induced plasma extravasation and adjuvant-induced arthritis in the rat. Proc Natl Acad Sci USA 88:4162-4165.

Greig AVH, James SE, McGrouther DA, Terenghi G, and Burnstock G (2003a) Purinergic receptor expression in the regenerating epidermis in a rat model of normal and delayed wound healing. Exp Dermatol 12:860-871.

Greig AVH, Linge C, Healy V, Lim P, Clayton E, Rustin MH, McGrouther DA, and Burnstock G (2003b) Expression of purinergic receptors in non-melanoma skin cancers and their functional roles in A431 cells. J Investig Dermatol 121:315-327.

Greig AVH, Linge C, Terenghi G, McGrouther DA, and Burnstock G (2003c) Purinergic receptors are part of a functional signalling system for proliferation and differentiation of human epidermal keratinocytes. J Investig Dermatol 120:10071015.

Gu JG (2003) P2X receptor-mediated modulation of sensory transmission to the spinal cord dorsal horn. Neuroscientist 9:370-378.

Guo LH and Schluesener HJ (2005) Lesional accumulation of $\mathrm{P}_{2} \mathrm{X}_{4}$ receptor ${ }^{+}$macrophages in rat CNS during experimental autoimmune encephalomyelitis. Neuro science 132:199-205.

Guo LH, Trautmann K, and Schluesener HJ (2005) Expression of $\mathrm{P}_{2} \mathrm{X}_{4}$ receptor by lesional activated microglia during formalin-induced inflammatory pain. $J \mathrm{Neu}$ roimmunol 163:120-127.

Gür S and Öztürk B (2000) Altered relaxant responses to adenosine and adenosine 5 -triphosphate in the corpus cavernosum from men and rats with diabetes. Pharmacology 60:105-112.

Hamilton SG, McMahon SB, and Lewin GR (2001) Selective activation of nociceptors by $\mathrm{P} 2 \mathrm{X}$ receptor agonists in normal and inflamed rat skin. $J$ Physiol (Lond) 534:437-445.

Han WJ, Kim SY, and Lee YB (2004) Neuroprotective effect of extracellular ATPinduced interleukin-10 expression in an in vitro model of brain ischemia, in 2004 Abstract Viewer/Itinerary Planner; Program no. 100.1. Society for Neuroscience, Washington, DC.

Harkema JM and Chaudry IH (1992) Magnesium-adenosine triphosphate in the treatment of shock, ischemia and sepsis. Crit Care Med 20:263-275.

Harvey RA, Skennerton DE, Newgreen D, and Fry CH (2002) The contractile potency of adenosine triphosphate and ecto-adenosine triphosphatase activity in guinea pig detrusor and detrusor from patients with a stable, unstable or obstructed bladder. J. Urol. 168:1235-1239.

Hase H, Joki N, Ishikawa H, Fukuda H, Imamura Y, Saijyo T, Tanaka Y, Takahashi Y, Inishi Y, Nakamura M, et al. (2004) Prognostic value of stress myocardial perfusion imaging using adenosine triphosphate at the beginning of haemodialysis treatment in patients with end-stage renal disease. Nephrol Dial Transplant 19:1161-1167.

Hashimoto M, Shinozuka K, Shahdat HM, Kwon YM, Tanabe Y, Kunitomo M, and Masumura S (1998) Antihypertensive effect of all-cis-5,8,11,14,17-icosapentaenoate of aged rats is associated with an increase in the release of ATP from the caudal artery. J Vasc Res 35:55-62.

Hatta Y, Aizawa S, Itoh T, Baba M, and Horie T (1994) Cytotoxic effect of extracellular ATP on L1210 leukemic cells and normal hemopoietic stem cells. Leuk Res 18:637-641.

Hatta Y, Takahashi M, Enomoto Y, Takahashi N, Sawada U, and Horie T (2004) Adenosine triphosphate (ATP) enhances the antitumor effect of etoposide (VP16) in lung cancer cells. Oncol Rep 12:1139-1142.

Hayes PD, Box H, Tull S, Bell PR, Goodall A, and Naylor AR (2003) Patients' thromboembolic potential after carotid endarterectomy is related to the platelets sensitivity to adenosine diphosphate. J Vasc Surg 38:1226-1231.

Hayton MJ, Dillon JP, Glynn D, Curran JM, Gallagher JA, and Buckley KA (2005) Involvement of adenosine 5 '-triphosphate in ultrasound-induced fracture repair. Ultrasound Med Biol 31:1131-1138.

Hegg CC, Davis K, and Lucero MT (2003a) Inhibition of heat-shock protein induction in mouse $\mathrm{OE}$ by in vivo administration of purinergic receptor antagonists. Chem Senses 28:A110.

Hegg CC, Greenwood D, Huang W, Han P, and Lucero MT (2003b) Activation of purinergic receptor subtypes modulates odor sensitivity. J Neurosci 23:82918301.

Hemmings-Mieszczak M, Dorn G, Natt FJ, Hall J, and Wishart WL (2003) Independent combinatorial effect of antisense oligonucleotides and RNAi-mediated specific inhibition of the recombinant rat $\mathrm{P}_{2} \mathrm{X}_{3}$ receptor. Nucleic Acids Res 31:2117-2126 Hervas C, Perez-Sen R, and Miras-Portugal MT (2003) Coexpression of functional 
P2X and P2Y nucleotide receptors in single cerebellar granule cells. J Neurosci Res 73:384-399.

Hetherington SL, Singh RK, Ladwick D, Thompson JR, Goodall AH, and Samani NJ (2004) Genetic regulation of the platelet adenosine diphosphate (ADP) response. Heart 90:A54.

Hillaire-Buys D, Bertrand G, Chapal J, Puech R, Ribes G, and Loubatières-Mariani MM (1993) Stimulation of insulin secretion and improvement of glucose tolerance in rat and dog by the P2y-purinoceptor agonist, adenosine-5'-O-(2-thiodiphosphate). Br J Pharmacol 109:183-187.

Hillman KA, Woolf AS, Johnson TM, Wade A, Unwin RJ, and Winyard PJ (2004) The $\mathrm{P}_{7}$ ATP receptor modulates renal cyst development in vitro. Biochem Biophys Res Commun 322:434-439.

Hoebertz A, Arnett TR, and Burnstock G (2003) Regulation of bone resorption and formation by purines and pyrimidines. Trends Pharmacol Sci 24:290-297.

Hoebertz A, Meghji S, Burnstock G, and Arnett TR (2001) Extracellular ADP is a powerful osteolytic agent: evidence for signaling through the $\mathrm{P}_{2} \mathrm{Y}_{1}$ receptor on bone cells. FASEB J 15:1139-1148.

Hollopeter G, Jantzen H-M, Vincent D, Li G, England L, Ramakrishnan V, Yang R-B, Nurden P, Nurden A, Julius D, et al. (2001) Identification of the platelet ADP receptor targeted by antithrombotic drugs. Nature (Lond) 409:202-207.

Holzer P (2001) Gastrointestinal afferents as targets of novel drugs for the treatment of functional bowel disorders and visceral pain. Eur J Pharmacol 429:177-193.

Honore P, Mikusa J, Bianchi B, McDonald H, Cartmell J, Faltynek C, and Jarvis MF (2002) TNP-ATP, a potent $\mathrm{P}_{2} \mathrm{X}_{3}$ receptor antagonist, blocks acetic acid-induced abdominal constriction in mice: comparison with reference analgesics. Pain 96: 99-105.

Höpfner M, Lemmer K, Jansen A, Hanski C, Riecken EO, Gavish M, Mann B, Buhr $\mathrm{H}$, Glassmeier G, and Scherübl $\mathrm{H}$ (1998) Expression of functional $\mathrm{P}_{2}$-purinergic receptors in primary cultures of human colorectal carcinoma cells. Biochem Biophys Res Commun 251:811-817.

Hou M, Harden TK, Kuhn CM, Baldetorp B, Lazarowski E, Pendergast W, Moller S, Edvinsson L, and Erlinge D (2002) UDP acts as a growth factor for vascular smooth muscle cells by activation of $\mathrm{P}_{2} \mathrm{Y}_{6}$ receptors. Am J Physiol 282:H784H792.

Hou M, Malmsjo M, Moller S, Pantev E, Bergdahl A, Zhao XH, Sun XY, Hedner T, Edvinsson L, and Erlinge D (1999) Increase in cardiac P2X $\mathrm{X}^{-}$and $\mathrm{P}_{2} \mathrm{Y}_{2}$-receptor mRNA levels in congestive heart failure. Life Sci 65:1195-1206.

Housley GD (2000) Physiological effects of extracellular nucleotides in the inner ear. Clin Exp Pharmacol Physiol 27:575-580.

Hutchinson SA and Scammells PJ (2004) $\mathrm{A}_{1}$ adenosine receptor agonists: medicinal chemistry and therapeutic potential. Curr Pharm Des 10:2021-2039.

Imai M, Takigami K, Guckelberger O, Kaczmarek E, Csizmadia E, Bach FH, and Robson SC (2000) Recombinant adenoviral mediated CD39 gene transfer prolongs cardiac xenograft survival. Transplantation 70:864-870.

Inoue K (1998) ATP receptors for the protection of hippocampal functions. Jpn $J$ Pharmacol 78:405-410.

Inoue K (2002) Microglial activation by purines and pyrimidines. Glia 40:156-163. Inoue K, Tsuda M, and Koizumi K (2003) ATP induced three types of pain behaviors, including allodynia. Drug Dev Res 59:56-63.

Inoue K, Tsuda M, and Koizumi S (2004) ATP- and adenosine-mediated signaling in the central nervous system: chronic pain and microglia: involvement of the ATP receptor P2X . J Pharmacol Sci 94:112-114.

Inoue K, Tsuda M, and Koizumi S (2005) ATP receptors in pain sensation: involvement of spinal microglia and $\mathrm{P}_{2} \mathrm{X}_{4}$ receptors. Purinergic Signal 1:95-100.

Irnich D, Burgstahler R, and Grafe P (2001) P2 Nucleotide receptors in peripheral nerve trunk. Drug Dev Res 52:83-88.

Jackson EK (2001) P1 and P2 receptors in the renal system, in Purinergic and Pyrimidinergic Signalling II: Cardiovascular, Respiratory, Immune, Metabolic and Gastrointestinal Tract Function (Abbracchio MP and Williams M eds) pp 33-71, Springer-Verlag, Berlin.

Jacobson KA, Jarvis MF, and Williams M (2002) Purine and pyrimidine (P2) receptors as drug targets. J Med Chem 45:4057-4093.

Jahr CE and Jessell TM (1983) ATP excites a subpopulation of rat dorsal horn neurones. Nature (Lond) 304:730-733.

Jakobi H, Spinar H, Kuhl KD, Lotz P, and Haberland EJ (1977) Clinical and experimental use of ATP in internal ear diseases. Acta Otolaryngol 83:195-199.

James G and Butt AM (2002) P2Y and P2X purinoceptor mediated $\mathrm{Ca}^{2+}$ signalling in glial cell pathology in the central nervous system. Eur J Pharmacol 447:247260.

Janssens R and Boeynaems JM (2001) Effects of extracellular nucleotides and nucleosides on prostate carcinoma cells. Br J Pharmacol 132:536-546.

Jarvis MF (2003) Contributions of $\mathrm{P}_{2} \mathrm{X}_{3}$ homomeric and heteromeric channels to acute and chronic pain. Expert Opin Ther Targets 7:513-522.

Jarvis MF, Bianchi B, Uchic JT, Cartmell J, Lee CH, Williams M, and Faltynek C (2004) $\left[{ }^{3} \mathrm{H}\right] \mathrm{A}-317491$, a novel high-affinity non-nucleotide antagonist that specifically labels human $\mathrm{P}_{2 / 3}$ and $\mathrm{P}_{2} \mathrm{X}_{3}$ receptors. J Pharmacol Exp Ther 310:407416.

Jarvis MF, Burgard EC, McGaraughty S, Honore P, Lynch K, Brennan TJ, Subieta A, van Biesen T, Cartmell J, Bianchi B, et al. (2002) A-317491, a novel potent and selective non-nucleotide antagonist of $\mathrm{P}_{2} \mathrm{X}_{3}$ and $\mathrm{P} 2 \mathrm{X}_{2 / 3}$ receptors, reduces chronic inflammatory and neuropathic pain in the rat. Proc Natl Acad Sci USA 99:1717917184.

John GR, Simpson JE, Woodroofe MN, Lee SC, and Brosnan CF (2001) Extracellular nucleotides differentially regulate interleukin- $1 \beta$ signaling in primary human astrocytes: implications for inflammatory gene expression. J Neurosci 21:41344142

Joles JA and Koomans HA (2004) Causes and consequences of increased sympathetic activity in renal disease. Hypertension 43:699-706.

Jonzon B, Nilsson J, and Fredholm BB (1985) Adenosine receptor-mediated changes in cyclic AMP production and DNA synthesis in cultured arterial smooth muscle cells. J Cell Physiol 124:451-456.
Julius S and Nesbitt S (1996) Sympathetic overactivity in hypertension: a moving target. Am J Hypertens 9:113S-120S.

Jun D and Kim K (2004) ATP-mediated necrotic volume increase (NVI) in substantia nigra pars compacta dopaminergic neuron, 2004 Abstract Viewer/Itinerary Planner; Program no. 222.18. Society for Neuroscience, Washington, DC.

Kääpä P, Jahnukainen T, Gronlund J, Rautanen M, Halkola L, and Valimaki (1997) Adenosine triphosphate treatment for meconium aspiration-induced pulmonary hypertension in pigs. Acta Physiol Scand 160:283-289.

Kadowaki M, Yoneda S, and Takaki M (2003) Involvement of a purinergic pathway in the sympathetic regulation of motility in rat ileum. Auton Neurosci 104:10-16 Kam PC and Nethery CM (2003) The thienopyridine derivatives (platelet adenosine diphosphate receptor antagonists), pharmacology and clinical developments. Anaesthesia 58:28-35.

Kapoor JR and Sladek CD (2000) Purinergic and adrenergic agonists synergize in stimulating vasopressin and oxytocin release. J Neurosci 20:8868-8875.

Katircioglu SF, Ulus AT, and Saritas Z (2000) ATP- $\mathrm{MgCl}_{2}$ treatment after experimental acute myocardial ischemia and reperfusion. Panminerva Med 42:11-15.

Ke HZ, Qi H, Weidema AF, Zhang Q, Panupinthu N, Crawford DT, Grasser WA, Paralkar VM, Li M, Audoly LP, et al. (2003) Deletion of the P2X $\mathrm{X}_{7}$ nucleotide receptor reveals its regulatory roles in bone formation and resorption. Mol Endocrinol 17:1356-1367.

Kellerman D, Evans R, Mathews D, and Shaffer C (2002) Inhaled P2Y 2 receptor agonists as a treatment for patients with cystic fibrosis lung disease. Adv Drug Deliv Rev 54:1463-1474.

Kemp PA, Sugar RA, and Jackson AD (2004) Nucleotide-mediated mucin secretion from differentiated human bronchial epithelial cells. Am J Respir Cell Biol 31: $446-455$.

Kennedy C and Leff P (1995) Painful connection for ATP. Nature (Lond) 377:385386.

Khakh BS, Humphrey PP, and Henderson G (1997) ATP-gated cation channels (P2X purinoceptors) in trigeminal mesencephalic nucleus neurons of the rat. $J$ Physiol (Lond) 498:709-715.

Khakh BS, Gittermann D, Cockayne DA, and Jones A (2003) ATP modulation of excitatory synapses onto interneurons. $J$ Neurosci 23:7426-7437.

Kien ND, White DA, Reitan JA, and Eisele JH (1987) Cardiovascular function during controlled hypotension induced by adenosine triphosphate or sodium nitroprusside in the anesthetized dog. Anesth Analg 66:103-110.

Kimball BC and Mulholland MW (1996) Enteric glia exhibit $\mathrm{P}_{2 \mathrm{U}}$ receptors that increase cytosolic calcium by a phospholipase C-dependent mechanism. J Neurochem 66:604-612.

King BF, Wildman SS, Ziganshina LE, Pintor J, and Burnstock G (1997) Effects of extracellular $\mathrm{pH}$ on agonism and antagonism at a recombinant $\mathrm{P} 2 \mathrm{X}_{2}$ receptor. $\mathrm{Br} J$ Pharmacol 121:1445-1453.

King BF, Knowles I, Burnstock G, and Ramage A (2004) Investigation of the effects of P2 purinoceptor ligands on the micturition reflex in female urethaneanaesthetised rats. $\mathrm{Br}$ J Pharmacol 142:519-530.

King BF, Liu M, Townsend-Nicholson A, Pfister J, Padilla F, Ford APDW, Gever J, Oglesby IB, Schorge S, and Burnstock G (2005) Antagonism of ATP responses at $\mathrm{P} 2 \mathrm{X}$ receptor subtypes by the $\mathrm{pH}$ indicator dye, phenol red. $\mathrm{Br} J$ Pharmacol 145:313-322.

Kirkup AJ, Brunsden M, and Grundy D (2001) Receptors and transmission in the brain-gut axis: potential for novel therapies. I. Receptors on visceral afferents. Am J Physiol 280:G787-G794.

Kishore BK, Isaac J, Fausther M, Tripp SR, Shi H, Gill PS, Braun N, Zimmermann H, Sévigny J, and Robson SC (2005) Expression of NTPDase1 and NTPDase2 in murine kidney: relevance to regulation of $\mathrm{P} 2$ receptor signaling. Am $J$ Physiol 288:F1032-F1043

Kitahara S, Yamashita M, and Ikemoto Y (2003) Effects of pentobarbital on purinergic P2X receptors of rat dorsal root ganglion neurons. Can J Physiol Pharmacol 81:1085-1091.

Kitchen AM, Collins HL, DiCarlo SE, Scislo TJ, and O'Leary DS (2001) Mechanisms mediating NTS P2X receptor-evoked hypotension: cardiac output vs. total peripheral resistance. Am J Physiol 281:H2198-H2203.

Kittner H, Franke H, Fischer W, Schultheis N, Krugel U, and Illes P (2003) Stimulation of $\mathrm{P} 2 \mathrm{Y}_{1}$ receptors causes anxiolytic-like effects in the rat elevated plusmaze: implications for the involvement of $\mathrm{P}_{2} \mathrm{Y}_{1}$ receptor-mediated nitric oxide production. Neuropsychopharmacology 28:435-444.

Kittner H, Krugel U, El-Ashmawy IM, and Illes P (2000) Suppression of feedingevoked dopamine release in the rat nucleus accumbens by the blockade of $\mathrm{P}_{2}$ purinoceptors. Eur J Pharmacol 406:R13-R14.

Klepeis VE, Weinger I, Kaczmarek E, and Trinkaus-Randall V (2004) P2Y receptors play a critical role in epithelial cell communication and migration. J Cell Biochem 93:1115-1133.

Knight GE, Bodin P, de Groat WC, and Burnstock G (2002) ATP is released from guinea pig ureter epithelium on distension. Am J Physiol 282:F281-F288.

Knutsen LJS and Murray TF (1997) Adenosine and ATP in epilepsy, in Purinergic Approaches in Experimental Therapeutics (Jacobson KA and Jarvis MF eds) pp 423-447, Wiley-Liss, New York.

Ko WH, Au CL, and Yip CY (2003) Multiple purinergic receptors lead to intracellular calcium increases in cultured rat sertoli cells. Life Sci 72:1519-1535.

Köles L, Fürst S, and Illes P (2005) P2X and P2Y receptors as possible targets of therapeutic manipulators in CNS illnesses. Drug News Perspect 18:1-17.

Komarova SV, Dixon SJ, and Sims SM (2001) Osteoclast ion channels: potential targets for antiresorptive drugs. Curr Pharm Des 7:637-654.

Korcok J, Raimundo LN, Ke HZ, Sims SM, and Dixon SJ (2004) Extracellular nucleotides act through $\mathrm{P} 2 \mathrm{X}_{7}$ receptors to activate NF- $\kappa \mathrm{B}$ in osteoclasts. $J$ Bone Miner Res 19:642-651.

Kottgen M, Loffler T, Jacobi C, Nitschke R, Pavenstadt H, Schreiber R, Frische S, Nielsen S, and Leipziger J (2003) $\mathrm{P}_{2} \mathrm{Y}_{6}$ receptor mediates colonic $\mathrm{NaCl}$ secretion via differential activation of cAMP-mediated transport. J Clin Investig 111:371379 . 
Kouakam C, Lauwerier B, Klug D, Jarwe M, Marquie C, Lacroix D, and Kacet S (2003) Effect of elevated heart rate preceding the onset of ventricular tachycardia on antitachycardia pacing effectiveness in patients with implantable cardioverter defibrillators. Am J Cardiol 92:26-32.

Kowaluk EA and Jarvis MF (2000) Therapeutic potential of adenosine kinase inhibitors. Expert Opin Investig Drugs 9:551-564.

Kucher BM and Neary JT (2005) Bi-functional effects of ATP/P2 receptor activation on tumour necrosis factor- $\alpha$ release in lipopolysaccharide-stimulated astrocytes. $J$ Neurochem 92:525-535.

Kulkarni AA, Trousdale MD, Stevenson D, Gukasyan HJ, Shiue MH, Kim KJ, Read RW, and Lee VH (2003) Nucleotide-induced restoration of conjunctival chloride and fluid secretion in adenovirus type 5-infected pigmented rabbit eyes. $J$ Pharmacol Exp Ther 305:1206-1211.

Kumahashi N, Ochi M, Kataoka H, Uchio Y, Kakimaru H, Sugawara K, and Enomoto K (2004) Involvement of ATP, increase of intracellular calcium and the early expression of c-fos in the repair of rat fetal articular cartilage. Cell Tissue Res 317:117-128.

Kumar V, Templeman L, Chapple CR, and Chess-Williams R (2003) Recent developments in the management of detrusor overactivity. Curr Opin Urol 13:285-291.

Kunapuli SP, Ding Z, Dorsam RT, Kim S, Murugappan S, and Quinton TM (2003) ADP receptors-targets for developing antithrombotic agents. Curr Pharmacol Des 9:2303-2316.

Kusner DJ and Barton JA (2001) ATP stimulates human macrophages to kill intracellular virulent mycobacterium tuberculosis via calcium-dependent phagosome-lysosome fusion. J Immunol 167:3308-3315.

Lammas DA, Stober C, Harvey CJ, Kendrick N, Panchalingam S, and Kumararatne DS (1997) ATP-induced killing of mycobacteria by human macrophages is mediated by purinergic P2Z(P2X7) receptors. Immunity 7:433-444.

Lara DR and Souza DO (2000) Schizophrenia: a purinergic hypothesis. Med Hypotheses 54:157-166.

Lecci A, Santicioli P, and Maggi CA (2002) Pharmacology of transmission to gastrointestinal muscle. Curr Opin Pharmacol 2:630-641.

Lee DK, Gray RD, and Lipworth BJ (2003) Adenosine monophosphate bronchia provocation and the actions of asthma therapy. Clin Exp Allergy 33:287-294.

Lee H, Jun DJ, Suh BC, Choi BH, Lee JH, Do MS, Suh BS, Ha H, and Kim KT (2005 Dual roles of P2 purinergic receptors in insulin-stimulated leptin production and lipolysis in differentiated rat white adipocytes. J Biol Chem 280:28556-28563.

Lee SC and Pappone PA (1997) Effects of P2 purinergic receptor stimulation in brown adipocytes. Am J Physiol 273:C679-C686.

Lee YJ and Han HJ (2005) Effect of adenosine triphosphate in renal ischemic injury: involvement of NF- $\kappa$ B. J Cell Physiol 204:792-799.

Lemaire I and Leduc N (2004) Purinergic P2X $\mathrm{X}_{7}$ receptor function in lung alveolar macrophages: pharmacologic characterization and bidirectional regulation by $\mathrm{Th} 1$ and Th2 cytokines. Drug Dev Res 59:118-127.

Lemoli RM, Ferrari D, Fogli M, Rossi L, Pizzirani C, Forchap S, Chiozzi P, Vaselli D, Bertolini F, Foutz T, et al. (2004) Extracellular nucleotides are potent stimulator of human hematopoietic stem cells in vitro and in vivo. Blood 104:1662-1670.

Levy J, Rempinski D, and Kuo TH (1994) Hormone-specific defect in insulin regulation of $\left(\mathrm{Ca}^{2+}+\mathrm{Mg}^{2+}\right)$-adenosine triphosphatase activity in kidney membranes from streptozocin non-insulin-dependent diabetic rats. Metabolism 43:604-613.

Lewis C, Neidhart S, Holy C, North RA, Buell G, and Surprenant A (1995) Coexpression of $\mathrm{P}_{2} \mathrm{X}_{2}$ and $\mathrm{P} 2 \mathrm{X}_{3}$ receptor subunits can account for ATP-gated currents in sensory neurons. Nature (Lond) 377:432-435.

Liang BT and Jacobson KA (1999) Adenosine and ischemic preconditioning. Curr Pharm Des 5:1029-1041.

Liang SD, Gao Y, Xu CS, Xu BH, and Mu SN (2004) Effect of tetramethylpyrazine on acute nociception mediated by signaling of $\mathrm{P} 2 \mathrm{X}$ receptor activation in rat. Brain Res 995:247-252.

Liang SD, Xu CS, Zhou HQ, Liu Y, GaoY and Li GL (2005) Tetramethylpyrazine inhibits ATP-activated currents in rat dorsal root ganglion neurons. Brain Res 1040:92-97.

Livingston M, Heaney LG, and Ennis M (2004) Adenosine, inflammation and asthma-a review. Inflamm Res 53:171-178.

Loredo GA and Benton HP (1998) ATP and UTP activate calcium-mobilizing P2Ulike receptors and act synergistically with interleukin-1 to stimulate prostaglandin $\mathrm{E}_{2}$ release from human rheumatoid synovial cells. Arthritis Rheum 41:246-255.

Loubatières-Mariani MM, Hillaire-Buys D, Chapal J, Bertrand G, and Petit P (1997) P2 purinoceptor agonists: new insulin secretagogues potentially useful in the treatment of non-insulin-dependent diabetes mellitus, in Purinergic Approaches in Experimental Therapeutics (Jacobson KA and Jarvis MF eds) pp 253-260, WileyLiss, New York

Lu SH, Fraser MO, Chancellor MB, Cheng CL, and de Groat WC (2002) Voiding dysfunction and purinergic mechanisms in awake chronic spinal cord injured (SCI) rats, in 2004 Abstract Viewer/Itinerary Planner; Program no. 68.6. Society for Neuroscience, Washington, DC.

Luttikhuizen DT, Harmsen MC, de Leij LF, and van Luyn MJ (2004) Expression of P2 receptors at sites of chronic inflammation. Cell Tissue Res 317:289-298.

Macdonald RL (2000) Editorial comment. Stroke 31:1384-1385.

Machado-Vieira R, Lara DR, Souza DO, and Kapczinski F (2002) Purinergic dysfunction in mania: an integrative model. Med Hypotheses 58:297-304

Mall M, Wissner A, Gonska T, Calenborn D, Kuehr J, Brandis M, and Kunzelmann $\mathrm{K}$ (2000) Inhibition of amiloride-sensitive epithelial $\mathrm{Na}^{+}$absorption by extracellular nucleotides in human normal and cystic fibrosis airways. Am J Respir Cell Mol Biol 23:755-761.

Maminishkis A, Jalickee S, Blaug SA, Rymer J, Yerxa BR, Peterson WM, and Miller SS (2002) The $\mathrm{P}_{2} \mathrm{Y}_{2}$ receptor agonist INS37217 stimulates RPE fluid transport in vitro and retinal reattachment in rat. Investig Ophthalmol Vis Sci 43:3555-3566.

Mantuano-Barradas M, Henriques-Pons A, Araujo-Jorge TC, Di Virgillio F, Coutinho-Silva R, and Persechini PM (2003) Extracellular ATP induces cell death in $\mathrm{CD}^{+} / \mathrm{CD}^{+}$double-positive thymocytes in mice infected with Trypanosoma cruzi. Microbes Infect 5:1363-1371.
Mantyh PW, Clohisy DR, Koltzenburg M, and Hunt SP (2002) Molecular mechanisms of cancer pain. Nat Rev Cancer 2:201-209.

Marcus AJ, Broekman MJ, Drosopoulos JH, Islam N, Pinsky DJ, Sesti C, and Levi R (2003) Metabolic control of excessive extracellular nucleotide accumulation by CD39/ecto-nucleotidase-1: implications for ischemic vascular diseases. J Pharmacol Exp Ther 305:9-16.

Matsagas M, Jagroop IA, Geroulakos G, and Mikhailidis DP (2003) The effect of a loading dose $(300 \mathrm{mg})$ of clopidogrel on platelet function in patients with peripheral arterial disease. Clin Appl Thromb Hemost 9:115-120.

Matsumoto N, Sorimachi M, and Akaike N (2004) Excitatory effects of ATP on rat dorsomedial hypothalamic neurons. Brain Res 1009:234-237.

McCallion K, Harkin DW, and Gardiner KR (2004) Role of adenosine in immunomodulation: review of the literature. Crit Care Med 32:273-277.

McGaraughty S, Honore P, Wismer CT, Mikusa J, Zhu CZ, McDonald HA, Bianchi B, Faltynek CR, and Jarvis MF (2005) Endogenous opioid mechanisms partially mediate $\mathrm{P}_{2} \mathrm{X}_{3} / \mathrm{P} 2 \mathrm{X}_{2 / 3}$-related antinociception in rat models of inflammatory and chemogenic pain but not neuropathic pain. Br J Pharmacol 146:180-188.

McGaraughty S, Wismer CT, Zhu CZ, Mikusa J, Honore P, Chu KL, Lee CH, Faltynek CR, and Jarvis MF (2003) Effects of A-317491, a novel and selective $\mathrm{P} 2 \mathrm{X}_{3} / \mathrm{P} 2 \mathrm{X}_{2 / 3}$ receptor antagonist, on neuropathic, inflammatory and chemogenic nociception following intrathecal and intraplantar administration. $\mathrm{Br} J$ Pharmacol 140:1381-1388.

McNamara N, Gallup M, Khong A, Sucher A, Maltseva I, Fahy JV, and Basbaum C (2004) Adenosine up-regulation of the mucin gene, MU2, in asthma. FASEB $J$ 18:1770-1772.

Meade CJ, Dumont I, and Worrall L (2001) Why do asthmatic subjects respond so strongly to inhaled adenosine? Life Sci 69:1225-1240.

Meme W, Ezan P, Venance L, Glowinski J, and Giaume C (2004) ATP-induced inhibition of gap junctional communication is enhanced by interleukin- $1 \beta$ treatment in cultured astrocytes. Neuroscience 126:95-104.

Mietz H, Chevez-Barrios P, Feldman RM, and Lieberman MW (1998) Suramin inhibits wound healing following filtering procedures for glaucoma. Br J Ophthal mol 82:816-820.

Mizumoto N, Mummert ME, Shalhevet D, and Takashima A (2003) Keratinocyte ATP release assay for testing skin-irritating potentials of structurally diverse chemicals. J Investig Dermatol 121:1066-1072.

Mizuno K, Okamoto H, and Horio T (2004) Inhibitory influences of xanthine oxidase inhibitor and angiotensin I-converting enzyme inhibitor on multinucleated giant cell formation from monocytes by downregulation of adhesion molecules and purinergic receptors. Br J Dermatol 150:205-210

Mockett BG, Housley GD, and Thorne PR (1994) Fluorescence imaging of extracel lular purinergic receptor sites and putative ecto-ATPase sites on isolated cochlear hair cells. $J$ Neurosci 14:6992-7007.

Morciano M, Ortinau S, and Zimmermann H (2004) Guanine nucleotides inhibit NMDA and kainate-induced neurotoxicity in cultured rat hippocampal and neocortical neurons. Neurochem Int 45:95-101.

Moreland RB, Brioni JD, and Sullivan JP (2004) Emerging pharmacologic approaches for the treatment of lower urinary tract disorders. J Pharmacol Exp Ther 308:797-804.

Mori M, Heuss C, Gahwiler BH, and Gerber U (2001) Fast synaptic transmission mediated by P2X receptors in CA3 pyramidal cells of rat hippocampal slice cultures. I Physiol (Lond) 535:115-123.

Mori M, Tsushima H, and Matsuda T (1994) Antidiuretic effects of ATP induced by microinjection into the hypothalamic supraoptic nucleus in water-loaded and ethanol-anesthetized rats. Jpn J Pharmacol 66:445-450.

Moriyama T, Iida T, Kobayashi K, Higashi T, Fukuoka T, Tsumura H, Leon C, Suzuki N, Inoue K, Gachet C, et al. (2003) Possible involvement of $\mathrm{P}_{2} \mathrm{Y}_{2}$ metabotropic receptors in ATP-induced transient receptor potential vanilloid receptor 1-mediated thermal hypersensitivity. J Neurosci 23:6058-6062.

Mork H, Ashina M, Bendtsen L, Olesen J, and Jensen R (2003) Experimental muscle pain and tenderness following infusion of endogenous substances in humans. Eur $J$ Pain 7:145-153

Mukai C and Okuno M (2004) Glycolysis plays a major role for adenosine triphosphate supplementation in mouse sperm flagellar movement. Biol Reprod 71:540 547.

Mulligan SJ and MacVicar BA (2004) Calcium transients in astrocyte endfeet cause cerebrovascular constrictions. Nature (Lond) 431:195-199.

Munoz DJ, Kendrick IS, Rassam M, and Thorne PR (2001) Vesicular storage of adenosine triphosphate in the guinea-pig cochlear lateral wall and concentrations of ATP in the endolymph during sound exposure and hypoxia. Acta Otolaryngol 121:10-15

Murakami K, Nakamura Y, and Yoneda Y (2003) Potentiation by ATP of lipopolysaccharide-stimulated nitric oxide production in cultured astrocytes. Neuroscience 117:37-42.

Murakami T, Fujihara T, Nakamura M, and Nakata K (2000) $\mathrm{P}_{2} \mathrm{Y}_{2}$ receptor stimulation increases tear fluid secretion in rabbits. Curr Eye Res 21:782-787.

Nabekura T, Tomohiro M, Ito Y, and Kitagawa S (2004) Changes in plasma membrane $\mathrm{Ca}^{2+}$-ATPase expression and ATP content in lenses of hereditary cataract UPL rats. Toxicology 197:177-183.

Naemsch LN, Du X, Sims SM, and Dixon SJ (2001) P2 nucleotide receptors in osteoclasts. Drug Dev Res 53:130-139.

Nakano H, Furuya K, and Yamagishi S (2001) Synergistic effects of ATP on oxytocininduced intracellular $\mathrm{Ca}^{2+}$ response in mouse mammary myoepithelial cells. Pflueg Arch Eur J Physiol 442:57-63.

Nalos M, Asfar P, Ichai C, Radermacher P, Leverve XM, and Froba G (2003) Adenosine triphosphate-magnesium chloride: relevance for intensive care. Intensive Care Med 29:10-18.

Nathanson MH, Burgstahler AD, Masyuk A, and LaRusso NF (2001) Stimulation of ATP secretion in the liver by therapeutic bile acids. Biochem $J$ 358:1-5.

Naus CC, Ozog MA, Bechberger JF, and Nakase T (2001) A neuroprotective role for gap junctions. Cell Commun Adhes 8:325-328. 
Neary JT, Kang Y, and Shi YF (2004) Signaling from nucleotide receptors to protein kinase cascades in astrocytes. Neurochem Res 29:2037-2042.

Neary JT, Kang Y, Tran M, and Feld J (2005) Traumatic injury activates protein kinase B/Akt in cultured astrocytes: role of extracellular ATP and P2 purinergic receptors. J Neurotrauma 22:491-500.

Neary JT, Kang Y, Willoughby KA, and Ellis EF (2003) Activation of extracellular signal-regulated kinase by stretch-induced injury in astrocytes involves extracellular ATP and P2 purinergic receptors. J Neurosci 23:2348-2356.

Neary JT, McCarthy M, Cornell-Bell A, and Kang Y (1999) Trophic signaling pathways activated by purinergic receptors in rat and human astroglia. Prog Brain Res 120:323-332.

Needleman P, Minkes MS, and Douglas JR (1974) Stimulation of prostaglandin biosynthesis by adenine nucleotides. Profile of prostaglandin release by perfused organs. Circ Res 34:455-460.

Neuhuber WL and Tiegs G (2004) Innervation of immune cells: evidence for neuroimmunomodulation in the liver. Anat Rec 280A:884-892.

Newman EA (2003) Glial cell inhibition of neurons by release of ATP. J Neurosci 23:1659-1666

Nishiguchi J, Sasaki K, Seki S, Chancellor MB, Erickson KA, de Groat WC, Kumon $\mathrm{H}$, and Yoshimura N (2004) Effects of isolectin B4-conjugated saporin, a targeting cytotoxin, on bladder overactivity induced by bladder irritation. Eur J Neurosci 20:474-482.

Nishiyama A and Navar LG (2002) ATP mediates tubuloglomerular feedback. Am J Physiol 283:R273-R275.

North RA (2004) $\mathrm{P}_{3} \mathrm{X}_{3}$ receptors and peripheral pain mechanisms. J Physiol (Lond) 554:301-308

Nylander S, Mattsson C, Ramstrom S, and Lindahl TL (2004) Synergistic action between inhibition of $\mathrm{P} 2 \mathrm{Y}_{12} / \mathrm{P} 2 \mathrm{Y}_{1}$ and $\mathrm{P} 2 \mathrm{Y}_{12} /$ thrombin in ADP- and thrombininduced human platelet activation. Br J Pharmacol 142:1325-1331.

Nylund G, Nordgren S, and Delbro DS (2004) Expression of $\mathrm{P}_{2} \mathrm{Y}_{2}$ purinoceptors in MCG 101 murine sarcoma cells and HT-29 human colon carcinoma cells. Auton Neurosci 112:69-79.

Ogata T, Chuai M, Morino T, Yamamoto H, Nakamura Y, and Schubert P (2003) Adenosine triphosphate inhibits cytokine release from lipopolysaccharideactivated microglia via P2Y receptors. Brain Res 981:174-183.

Okada M, Nakagawa T, Minami M, and Satoh M (2002) Analgesic effects of intrathecal administration of P2Y nucleotide receptor agonists UTP and UDP in normal and neuropathic pain model rats. J Pharmacol Exp Ther 303:66-73.

Okusa MD (2002) $\mathrm{A}_{2 \mathrm{~A}}$ adenosine receptor: a novel therapeutic target in renal disease. Am J Physiol 282:F10-F18.

Omatsu-Kanbe M, Isono T, and Matsuura H (2002) Multiple P2 receptors contribute to a transient increase in intracellular $\mathrm{Ca}^{2+}$ concentration in ATP-stimulated rat brown adipocytes. Exp Physiol 87:643-652.

O'Reilly BA, Kosaka AH, Knight GE, Chang TK, Ford APDW, Rymer JM, Popert R, Burnstock G, and McMahon SB (2002) P2X receptors and their role in female idiopathic detrusor instability. J Urol 167:157-164.

Ouslander JG (2004) Management of overactive bladder. N Engl J Med 350:786799.

Pankratov YV, Lalo UV, and Krishtal OA (2002) Role for P2X receptors in long-term potentiation. J Neurosci 22:8363-8369.

Papka RE, Hafemeister J, and Storey-Workley M (2005) P2X receptors in the rat uterine cervix, lumbosacral dorsal root ganglia and spinal cord during pregnancy. Cell Tissue Res 321:35-44.

Parvathenani LK, Tertyshnikova S, Greco CR, Roberts SB, Robertson B, and Posmantur R (2003) $\mathrm{P} 2 \mathrm{X}_{7}$ mediates superoxide production in primary microglia and is up-regulated in a transgenic mouse model of Alzheimer's disease. J Biol Chem 278:13309-13317.

Pascual O and Haydon PG (2003) Synaptic inhibition mediated by glia. Neuron 40:873-875.

Pelleg A, Pennock RS, and Kutalek SP (2002). Proarrhythmic effects of adenosine: one decade of clinical data. Am J Ther 9:141-147.

Peroutka SJ (2004) Migraine: a chronic sympathetic nervous system disorder. Headache 44:53-64

Pintor J (2000) Purinergic signalling in the eye. in Nervous Control of the Eye (Burnstock G and Sillito A eds) pp 171-210, Harwood Academic Publishers, London.

Pintor J, Bautista A, Carracedo G, and Peral A (2004) UTP and diadenosine tetraphosphate accelerate wound healing in the rabbit cornea. Ophthalmic Physiol Opt 24:186-193.

Pintor J and Peral A (2001) Therapeutic potential of nucleotides in the eye. Drug Dev Res 52:190-195.

Pintor J, Peral A, Pelaez T, Carracedo G, Bautista A, and Hoyle CH (2003a) Nucleotides and dinucleotides in ocular physiology: new possibilities of nucleotides as therapeutic agents in the eye. Drug Dev Res 59:136-145

Pintor J, Peral A, Pelaez T, Martin S, and Hoyle CH (2003b) Presence of diadenosine polyphosphates in the aqueous humor: their effect on intraocular pressure. J Phar macol Exp Ther 304:342-348.

Pochmann D, Rücker B, Battastini AMO, and Sarkis JJF (2004) Ovariectomy and estrodiol replacement therapy alters the adenine nucleotide hydrolysis in rat blood serum. Thromb Res 114:275-281.

Polosa R, Rorke S, and Holgate ST (2002) Evolving concepts on the value of adenosine hyperresponsiveness in asthma and chronic obstructive pulmonary disease. Thorax 57:649-654

Poole DP, Castelucci P, Robbins HL, Chiocchetti R, and Furness JB (2002) The distribution of $\mathrm{P}_{2} \mathrm{X}_{3}$ purine receptor subunits in the guinea pig enteric nervous system. Auton Neurosci 101:39-47.

Premkumar LS (2001) Interaction between vanilloid receptors and purinergic metabotropic receptors: pain perception and beyond. Proc Natl Acad Sci USA 98:6537-6539.

Punj V, Zaborina O, Dhiman N, Falzari K, Bagdasarian M, and Chakrabarty AM
(2000) Phagocytic cell killing mediated by secreted cytotoxic factors of Vibrio cholerae. Infect Immun 68:4930-4937.

Ralevic V and Burnstock G (1998) Receptors for purines and pyrimidines. Pharmacol Rev 50:413-492.

Ralevic V and Burnstock G (2003) Involvement of purinergic signalling in cardiovascular diseases. Drug News Perspect 16:133-140.

Rapaport E (1983) Treatment of human tumor cells with ADP or ATP yields arrest of growth in the S phase of the cell cycle. J Cell Physiol 114:279-283.

Rapp DE, Lyon MB, Bales GT, and Cook SP (2005) A role for the P2X receptor in urinary tract physiology and in the pathophysiology of urinary dysfunction. Eur Urol 48:303-308.

Rathbone MP, Middlemiss PJ, Gysbers JW, Andrew C, Herman MA, Reed JK, Ciccarelli R, Di Iorio P, and Caciagli F (1999) Trophic effects of purines in neurons and glial cells. Prog Neurobiol 59:663-690.

Ray FR, Huang W, Slater M, and Barden JA (2002) Purinergic receptor distribution in endothelial cells in blood vessels: a basis for selection of coronary artery grafts. Atherosclerosis 162:55-61.

Rees DA, Scanlon MF, and Ham J (2003) Novel insights into how purines regulate pituitary cell function. Clin Sci (Lond) 104:467-481.

Regnier M, Rivera AJ, Chen Y, and Chase PB (2000) 2-Deoxy-ATP enhances contractility of rat cardiac muscle. Circ Res 86:1211-1217.

Renton T, Yiangou Y, Baecker PA, Ford AP, and Anand P (2003) Capsaicin receptor VR1 and ATP purinoceptor $\mathrm{P}_{2} \mathrm{X}_{3}$ in painful and nonpainful human tooth pulp. $J$ Orofac Pain 17:245-250.

Ribeiro JA, Sebastião AM, and de Mendonça A (2003) Adenosine receptors in the nervous system: pathophysiological implications. Prog Neurobiol 68:377-392.

Rich PB, Douillet CD, Mahler SA, Husain SA, and Boucher RC (2003) Adenosine triphosphate is released during injurious mechanical ventilation and contributes to lung edema. J Trauma 55:290-297.

Roberts VHJ, Brockman DE, Pitzer BA, Webster R, and Myatt L (2005) P2X purinergic receptor protein expression is upregulated in placenta from preeclamptic pregnancies. J Soc Gynecol Investig 12:P363A.

Robson SC, Enjyoji K, Goepfert C, Imai M, Kaczmarek E, Lin Y, Sevigny J, and Warny M (2001) Modulation of extracellular nucleotide-mediated signaling by CD39/nucleoside triphosphate diphosphohydrolase-1. Drug Dev Res 53:193-207.

Rocha I, Burnstock G, and Spyer KM (2001) Effect on urinary bladder function and arterial blood pressure of the activation of putative purine receptors in brainstem areas. Auton Neurosci 88:6-15.

Rong W and Burnstock G (2004) Activation of ureter nociceptors by exogenous and endogenous ATP in guinea pig. Neuropharmacology 47:1093-1101.

Rong W, Burnstock G, and Spyer KM (2000) P2X purinoceptor-mediated excitation of trigeminal lingual nerve terminals in an in vitro intra-arterially perfused rat tongue preparation. J Physiol (Lond) 524:891-902.

Rong W, Spyer M, and Burnstock G (2002) Activation and sensitisation of low and high threshold afferent fibres mediated by P2X receptors in the mouse urinary bladder. J Physiol (Lond) 541:591-600.

Rossato M, La Sala GB, Balasini M, Taricco F, Galeazzi C, Ferlin A, and Foresta C (1999) Sperm treatment with extracellular ATP increases fertilization rates in in-vitro fertilization for male factor infertility. Hum Reprod 14:694-697.

Rost S, Daniel C, Schulze-Lohoff E, Baumert HG, Lambrecht G, and Hugo C (2002) $\mathrm{P} 2$ receptor antagonist PPADS inhibits mesangial cell proliferation in experimental mesangial proliferative glomerulonephritis. Kidney Int 62:1659-1671.

Ruan HZ and Burnstock G (2003) Localisation of $\mathrm{P}_{2} \mathrm{Y}_{1}$ and $\mathrm{P}_{2} \mathrm{Y}_{4}$ receptors in dorsal root, nodose and trigeminal ganglia of the rat. Histochem Cell Biol 120:415-426. Ryan LM, Rachow JW, and McCarty DJ (1991) Synovial fluid ATP: a potential substrate for the production of inorganic pyrophosphate. J Rheumatol 18:716-720.

Ryten M, Yang SY, Dunn PM, Goldspink G, and Burnstock G (2004) Purinoceptor expression in regenerating skeletal muscle in the $\mathrm{mdx}$ mouse model of muscular dystrophy and in satellite cell cultures. FASEB $J$ 18:1404-1406.

Saini HK, Shao Q, Musat S, Takeda N, Tappia PS, and Dhalla NS (2005) Imidapril treatment improves the attenuated inotropic and intracellular calcium responses to ATP in heart failure due to myocardial infarction. Br J Pharmacol 144:202-211. Sanz JM and Di Virgilio F (2000) Kinetics and mechanism of ATP-dependent IL-1 $\beta$ release from microglial cells. J Immunol 164:4893-4898.

Saunders BM, Fernando SL, Sluyter R, Britton WJ, and Wiley JS (2003) A loss-offunction polymorphism in the human $\mathrm{P}_{2} \mathrm{X}_{7}$ receptor abolishes ATP-mediated killing of mycobacteria. J Immunol 171:5442-5446.

Sawynok J and Liu XJ (2003) Adenosine in the spinal cord and periphery: release and regulation of pain. Prog Neurobiol 69:313-340.

Schmidt M and Loffler G (1998) Induction of aromatase activity in human adipose tissue stromal cells by extracellular nucleotides-evidence for P2-purinoceptors in adipose tissue. Eur J Biochem 252:147-154.

Schnurr M, Toy T, Stoitzner P, Cameron P, Shin A, Beecroft T, Davis ID, Cebon J, and Maraskovsky E (2003) ATP gradients inhibit the migratory capacity of specific human dendritic cell types: implications for $\mathrm{P}_{2} \mathrm{Y}_{11}$ receptor signaling. Blood 102: $613-620$.

Schodel J, Weise I, Klinger R, and Schmidt M (2004) Stimulation of lipogenesis in rat adipocytes by ATP, a ligand for P2-receptors. Biochem Biophys Res Commun 321:767-773.

Schofl C, Rossig L, Potter E, von zur Muhlen A and Brabant G (1995) Extracellular ATP and UTP increase cytosolic free calcium by activating a common P2u-receptor in single human thyrocytes. Biochem Biophys Res Commun 213:928-934.

Schulman ES, Glaum MC, Post T, Wang Y, Raible DG, Mohanty J, Butterfield JH, and Pelleg A (1999) ATP modulates anti-IgE-induced release of histamine from human lung mast cells. Am J Respir Cell Mol Biol 20:530-537.

Schwiebert EM (2003) Cellular mechanisms and physiology of nucleotide and nucleoside release from cells: current knowledge, novel assays to detect purinergic agonists, and future directions. Curr Top Membr 54:31-58.

Schwiebert EM, Wallace DP, Braunstein GM, King SR, Peti-Peterdi J, Hanaoka K, Guggino WB, Guay-Woodford LM, Bell PD, Sullivan LP, et al. (2002) Autocrine 
extracellular purinergic signaling in epithelial cells derived from polycystic kidneys. Am J Physiol 282:F763-F775.

Scislo TJ, Kitchen AM, Augustyniak RA, and O'Leary DS (2001) Differential patterns of sympathetic responses to selective stimulation of nucleus tractus solitarius purinergic receptor subtypes. Clin Exp Pharmacol Physiol 28:120-124.

Selzner N, Selzner M, Graf R, Ungethuem U, Fitz JG, and Clavien P-A (2004) Water induces autocrine stimulation of tumour cell killing through ATP release and P2 receptor binding. Cell Death Differ 11:S172-S180.

Sesti C, Broekman MJ, Drosopoulos JH, Islam N, Marcus AJ, and Levi R (2002) Ectonucleotidase in cardiac sympathetic nerve endings modulates ATP-mediated feedback of norepinephrine release. J Pharmacol Exp Ther 300:605-611.

Sevigny J, Sundberg C, Braun N, Guckelberger O, Csizmadia E, Qawi I, Imai M, Zimmermann H, and Robson SC (2002) Differential catalytic properties and vascular topography of murine nucleoside triphosphate diphosphohydrolase 1 (NTP Dase1) and NTPDase2 have implications for thromboregulation. Blood 99:28012809

Seye CI, Yu N, Jain R, Kong Q, Minor T, Newton J, Erb L, Gonzalez FA, and Weisman GA (2003) The P2Y $\mathrm{Y}_{2}$ nucleotide receptor mediates UTP-induced vascular cell adhesion molecule-1 expression in coronary artery endothelial cells. $J$ Bio Chem 278:24960-24965.

Shabbir M, Thompson CS, Mikhailidis DP, Morgan RJ, and Burnstock G (2003) Extracellular ATP attenuates the growth of hormone refractory prostate cancer in vivo, in 5th World Congress of Urological Research; 2003 Sep 24-27; Kensington, London, UK.

Shabbir M, Thompson CS, Mikhailidis DP, Morgan RJ, and Burnstock G (2004) Adenosine 5'-triphosphate (ATP) increases the cytotoxic effect of mitomycin C in the treatment of high-grade bladder cancer. J Urol 171 (Suppl 4):260.

Shields CB, Zhang YP, Chen S, Han Y, Shields LBE, Chiang B, Burke DA, and Haskins R (2004) Treatment of spinal cord injury via topical perfusion with an ATP solution, in 2004 Abstract Viewer/Itinerary Planner; Program no. 418.8 Society for Neuroscience, Washington, DC.. Program no. 418.8.

Shinoda M, Ozaki N, Asai H, Nagamine K, and Sugiura Y (2005) Changes in P2X receptor expression in the trigeminal ganglion following monoarthritis of the temporomandibular joint in rats. Pain 116:42-51.

Shirley DG, Bailey MA, and Unwin RJ (2005) In vivo stimulation of apical P2 receptors in collecting ducts: evidence for inhibition of sodium reabsorption. Am J Physiol 288:F1243-F1248.

Sikora A, Liu J, Brosnan C, Buell G, Chessel I, and Bloom BR (1999) Cutting edge: purinergic signaling regulates radical-mediated bacterial killing mechanisms in macrophages through a $\mathrm{P}_{2} \mathrm{X}_{7}$-independent mechanism. J Immunol 163:558-561.

Silinsky EM, Gerzanich V, and Vanner SM (1992) ATP mediates excitatory synaptic transmission in mammalian neurones. Br J Pharmacol 106:762-763.

Simola N, Fenu S, Baraldi PG, Tabrizi MA, and Morelli M (2004) Blockade of adenosine $\mathrm{A} 2 \mathrm{~A}$ receptors antagonizes parkinsonian tremor in the rat tacrine model by an action on specific striatal regions. Exp Neurol 189:182-188.

Sinoway LI and Li J (2005) A perspective on the muscle reflex: implications for congestive heart failure. J Appl Physiol 99:5-22.

Sissons J, Alsam S, Jayasekera S, and Khan NA (2004) Ecto-ATPases of clinical and non-clinical isolates of Acanthamoeba. Microb Pathog 37:231-239.

Smith CP, Radziszewski P, Borkowski A, Somogyi GT, Boone TB, and Chancellor MB (2004) Botulinum toxin A has antinociceptive effects in treating interstitia cystitis. Urology 64:871-875

Smitham JE and Barrett KE (2001) Differential effects of apical and basolateral uridine triphosphate on intestinal epithelial chloride secretion. Am J Physiol 280:C1431-C1439.

Solini A, Chiozzi P, Morelli A, Passaro A, Fellin R, and Di Virgilio F (2003) Defective $\mathrm{P} 2 \mathrm{Y}$ purinergic receptor function: a possible novel mechanism for impaired glucose transport. J Cell Physiol 197:435-444.

Solini A, Iacobini C, Ricci C, Chiozzi P, Amadio L, Pricci F, Di Mario U, Di Virgilio F, and Pugliese G (2005) Purinergic modulation of mesangial extracellular matrix production: role in diabetic and other glomerular diseases. Kidney Int 67:875-885.

Somers GR, Hammet FM, Trute L, Southey MC, and Venter DJ (1998) Expression of the $\mathrm{P}_{2} \mathrm{Y}_{6}$ purinergic receptor in human $\mathrm{T}$ cells infiltrating inflammatory bowel disease. Lab Investig 78:1375-1383.

Sommer JA, Fisette PL, Hu Y, Denlinger LC, Guerra AN, Bertics PJ, and Proctor RA (1999) Purinergic receptor modulation of LPS-stimulated signaling events and nitric oxide release in RAW 264.7 macrophages. J Endotoxin Res 5:70-74.

Sommerschild HT and Kirkeboen KA (2000) Adenosine and cardioprotection during ischaemia and reperfusion-an overview. Acta Anaesthesiol Scand 44:1038-1055.

Sone H, Sasaki Y, Komai M, Toyomizu M, Kagawa Y, and Furukawa Y (2004) Biotin enhances ATP synthesis in pancreatic islets of the rat, resulting in reinforcement of glucose-induced insulin secretion. Biochem Biophys Res Commun 314:824-829.

Sorkin LS, Maruyama K, Boyle DL, Yang L, Marsala M, and Firestein GS (2003) Spinal adenosine agonist reduces c-fos and astrocyte activation in dorsal horn of rats with adjuvant-induced arthritis. Neurosci Lett 340:119-122.

Soto D, Pintor J, Peral A, Gual A, and Gasull X (2005) Effects of dinucleoside polyphosphates on trabecular meshwork cells and aqueous humor outflow facility. $J$ Pharmacol Exp Ther 314:1042-1051.

Spelta V, Jiang LH, Surprenant A, and North RA (2002) Kinetics of antagonist actions at rat $\mathrm{P} 2 \mathrm{X}_{2 / 3}$ heteromeric receptors. $\mathrm{Br} J$ Pharmacol 135:1524-1530.

Sperlágh B, Mergl Z, Jurányi Z, Vizi ES, and Makara GB (1999) Local regulation of vasopressin and oxytocin secretion by extracellular ATP in the isolated posterior lobe of the rat hypophysis. $J$ Endocrinol 160:343-350.

Sprague RS, Ellsworth ML, and Detrich HH (2003) Nucleotide release and purinergic signaling in the vasculature driven by the red blood cell. Curr Top Membr 54:243-268.

Sprague RS, Stephenson AH, Ellsworth ML, Keller C, and Lonigro AJ (2001) Impaired release of ATP from red blood cells of humans with primary pulmonary hypertension. Exp Biol Med (Maywood) 226:434-439.

Stevens B, Porta S, Haak LL, Gallo V, and Fields RD (2002) Adenosine: a neuron- glial transmitter promoting myelination in the CNS in response to action potentials. Neuron 36:855-868

Stober CB, Lammas DA, Li CM, Kumararatne DS, Lightman SL, and McArdle CA (2001) ATP-Mediated killing of Mycobacterium bovis bacille Calmette-Guérin within human macrophages is calcium dependent and associated with the acidification of mycobacteria-containing phagosomes. J Immunol 166:6276-6286.

Stojilkovic SS, Tomic M, Van GF, and Koshimizu T (2000) Expression of purinergic $\mathrm{P}_{2} \mathrm{X}_{2}$ receptor-channels and their role in calcium signaling in pituitary cells. Biochem Cell Biol 78:393-404

Stone LS and Vulchanova L (2003) The pain of antisense: in vivo application of antisense oligonucleotides for functional genomics in pain and analgesia. $A d v$ Drug Deliv Rev 55:1081-1112.

Stutts MJ and Boucher RC (1999) Cystic fibrosis gene and functions of CFTR implications of dysfunctional ion transport for pulmonary pathogenesis, in Cystic Fibrosis in Adults (Yankaskas JR and Knowles MR eds) pp 3-25, LippincottRaven, Philadelphia.

Sueta T, Paki B, Everett AW, and Robertson D (2003) Purinergic receptors in auditory neurotransmission. Hear Res 183:97-108

Sugahara K, Shimogori H, Okuda T, Takemoto T, Hashimoto M, and Yamashita H (2004) Cochlear administration of adenosine triphosphate facilitates recovery from acoustic trauma (temporary threshold shift). ORL J Otorhinolaryngol Relat Spec 66:80-84

Sugiyama T, Kobayashi M, Kawamura H, Li Q, Puro DG, and Kobayshi M (2004) Enhancement of $\mathrm{P}_{2} \mathrm{X}_{7}$-induced pore formation and apoptosis: an early effect of diabetes on the retinal microvasculature. Investig Ophthalmol Vis Sci 45:10261032.

Sumpio B, Baue AE, and Chaudry IH (1987) Treatment with verapamil and adenosine triphosphate- $\mathrm{MgCl}_{2}$ reduces cyclosporine nephrotoxicity. Surgery 101:315322

Sumpio BE, Chaudry IH, and Baue AE (1985) Reduction of the drug-induced nephrotoxicity by ATP- $\mathrm{MgCl}_{2}$. 1 . Effects on the cis-diamminedichloroplatinum-treated isolated perfused kidneys. J Surg Res 38:429-437.

Sumpio BE, Chaudry IH, Clemens MG, and Baue AE (1984) Accelerated functional recovery of isolated rat kidney with $\mathrm{ATP}-\mathrm{MgCl}_{2}$ after warm ischemia. $\mathrm{Am} J$ Physiol 247:R1047-R1053.

Sun Y and Chai TC (2002) Effects of dimethyl sulphoxide and heparin on stretchactivated ATP release by bladder urothelial cells from patients with interstitial cystitis. BJU Int 90:381-385.

Szalay KS, Orso E, Juranyi Z, Vinson GP, and Vizi ES (1998) Local non-synaptic modulation of aldosterone production by catecholamines and ATP in rat: implications for a direct neuronal fine tuning. Horm Metab Res 30:323-328.

Szentpali K, Kaszaki J, Tiszlavicz L, Lazar G, Balogh A, and Boros M (2001) Bile-induced adenosine triphosphate depletion and mucosal damage during reflux esophagitis. Scand J Gastroenterol 36:459-466.

Tai CJ, Kang SK, Choi KC, Tzeng CR, and Leung PC (2001) Antigonadotropic action of adenosine triphosphate in human granulosa-luteal cells: involvement of protein kinase $\mathrm{C} \alpha$. J Clin Endocrinol Metab 86:3237-3242.

Tan B-H, Shimizu H, Furukawa Y, Kanemori T, and Ohyanagi M (2004) Sinus slowing caused by adenosine-5'-triphosphate in patients with and without sick sinus syndrome under various autonomic states. J Endocrinol 37:305-309

Taylor AL, Schwiebert LM, Smith JJ, King C, Jones JR, Sorscher EJ, and Schwiebert EM (1999) Epithelial P2X purinergic receptor channel expression and function. $J$ Clin Investig 104:875-884

Tempest HV, Dixon AK, Turner WH, Elneil S, Sellers LA, and Ferguson DR (2004) $\mathrm{P}_{2} \mathrm{X}_{2}$ and $\mathrm{P}_{2} \mathrm{X}_{3}$ receptor expression in human bladder urothelium and changes in interstitial cystitis. BJU Int 93:1344-1348.

Thevananther S, Sun H, Li D, Arjunan V, Awad SS, Wyllie S, Zimmerman TL, Goss JA, and Karpen SJ (2004) Extracellular ATP activates C-jun N-terminal kinase signaling and cell cycle progression in hepatocytes. Hepatology 39:393-402.

Thompson GW, Horackova M, and Armour JA (2002) Role of $\mathrm{P}_{1}$ purinergic receptors in myocardial ischemia sensory transduction. Cardiovasc Res 53:888-901.

Tsai S-J (2005) Adenosine A2a receptor/dopamine D2 receptor hetero-oligomerization: a hypothesis that may explain behavioural sensitization to psychostimulant and schizophrenia. Med Hypotheses 64:197-200.

Tsuda M, Inoue K, and Salter MW (2005) Neuropathic pain and spinal microglia: a big problem from molecules in "small" glia. Trends Neurosci 28:101-107.

Tsuda M, Koizumi S, and Inoue K (2001) Role of endogenous ATP at the incision area in a rat model of postoperative pain. Neuroreport 12:1701-1704.

Tsuda M, Koizumi S, Kita A, Shigemoto Y, Ueno S, and Inoue K (2000) Mechanical allodynia caused by intraplantar injection of $\mathrm{P} 2 \mathrm{X}$ receptor agonist in rats: involvement of heteromeric $\mathrm{P}_{2 / 3}$ receptor signaling in capsaicin-insensitive primary afferent neurons. J Neurosci 20:RC90

Tsuda M, Shigemoto-Mogami Y, Koizumi S, Mizokoshi A, Kohsaka S, Salter MW, and Inoue K (2003) P2X receptors induced in spinal microglia gate tactile allodynia after nerve injury. Nature (Lond) 424:778-783.

Tsuzaki M, Bynum D, Almekinders L, Yang X, Faber J, and Banes AJ (2003) ATP modulates load-inducible IL-1 $\beta$, COX 2 and MMP-3 gene expression in human tendon cells. J Cell Biochem 89:556-562.

Turner C, Ramesh B, Srai SKS, Burnstock G, and Unwin R (2004a) Altered P2 receptor expression in the Han:SPRD cy/+ rat, a model of autosomal dominant polycystic kidney disease. Cell Tissues Organs 178:168-179.

Turner C, Tam FWK, Lai P-C, Tarzi RM, Burnstock G, Pusey CD, Cook HT, and Unwin R (2004b) Glomerular expression of the ATP-sensitive $\mathrm{P}_{2} \mathrm{X}_{7}$ receptor is increased in proliferative glomerulonephritis (Abstract). Society of Nephrology, Renal Week; 2004 Oct 27-Nov 1; St. Louis, MO

Turner JT, Landon LA, Gibbons SJ, and Talamo BR (1999) Salivary gland P2 nucleotide receptors. Crit Rev Oral Biol Med 10:210-224.

Ueda H and Rashid MH (2003) Molecular mechanism of neuropathic pain. Drug News Perspect 16:605-613.

Uhlmann S, Bringmann A, Uckermann O, Pannicke T, Weick M, Ulbricht E, Goczalik I, Reichenbach A, Wiedemann P, and Francke M (2003) Early glial cell 
reactivity in experimental retinal detachment: effect of suramin. Investig Ophthalmol Vis Sci 44:4114-4122.

Undem BJ, Chuaychoo B, Lee MG, Weinreich D, Myers AC, and Kollarik M (2004) Subtypes of vagal afferent C-fibres in guinea-pig lungs. J Physiol 556:905-917.

Unwin RJ, Bailey MA, and Burnstock G (2003) Purinergic signaling along the renal tubule: the current state of play. News Physiol Sci 18:237-241.

Van Nassauw L, Brouns I, Adriaensen D, Burnstock G, and Timmermans J-P (2002) Neurochemical identification of enteric neurons expressing $\mathrm{P} 2 \mathrm{X}_{3}$ receptors in the guinea-pig ileum. Histochem Cell Biol 118:193-203.

Vanderwinden JM, Timmermans JP, and Schiffmann SN (2003) Glial cells, but not interstitial cells, express $\mathrm{P}_{2} \mathrm{X}_{7}$, an ionotropic purinergic receptor, in rat gastrointestinal musculature. Cell Tissue Res 312:149-154.

Vanoverberghe K, Mariot P, Vanden AF, Delcourt P, Parys JB, and Prevarskaya N (2003) Mechanisms of ATP-induced calcium signaling and growth arrest in human prostate cancer cells. Cell Calcium 34:75-85.

Vassort G (2001) Adenosine 5'-triphosphate: a P2-purinergic agonist in the myocardium. Physiol Rev 81:767-806.

Vianna EP, Ferreira AT, Naffah-Mazzacoratti MG, Sanabria ER, Funke M, Cavalheiro EA and Fernandes MJ (2002) Evidence that ATP participates in the pathophysiology of pilocarpine-induced temporal lobe epilepsy: fluorimetric, immunohistochemical and western blot studies. Epilepsia 43 (Suppl 5):227-229.

Vinade ER, Schmidt AP, Frizzo ME, Izquierdo I, Elisabetsky E, and Souza DO (2003) Chronically administered guanosine is anticonvulsant, amnesic and anxiolytic in mice. Brain Res 977:97-102.

Virginio C, Robertson G, Surprenant A, and North RA (1998) Trinitrophenylsubstituted nucleotides are potent antagonists selective for $\mathrm{P}_{2} \mathrm{X}_{1}, \mathrm{P}_{2} \mathrm{X}_{3}$ and heteromeric $\mathrm{P}_{2 \mathrm{X}}$ receptors. Mol Pharmacol 53:969-973.

Vlaskovska M, Kasakov L, Rong W, Bodin P, Bardini M, Cockayne DA, Ford APDW, and Burnstock G (2001) P2X $\mathrm{X}_{3}$ knockout mice reveal a major sensory role for urothelially released ATP. J Neurosci 21:5670-5677.

Volonte C, Amadio S, Cavaliere F, D'Ambrosi N, Vacca F, and Bernardi G (2003) Extracellular ATP and neurodegeneration. Curr Drug Targets CNS Neurol Disord 2:403-412.

Volonte C, Ciotti MT, D’Ambrosi N, Lockhart B, and Spedding M (1999) Neuroprotective effects of modulators of P2 receptors in primary culture of CNS neurones. Neuropharmacology 38:1335-1342.

Vonend O, Turner C, Chan CM, Loesch A, Dell'Anna GC, Srai SK, Burnstock G, and Unwin R (2004) Glomerular expression of the ATP-sensitive $\mathrm{P}_{2} \mathrm{X}_{7}$ receptor in diabetic and hypertensive rat models. Kidney Int 66:157-166.

Vorhoff T, Zimmermann H, Pelletier J, Sévigny J, and Braun N (2005) Cloning and characterization of the ecto-nucleotidase NTPDase3 from rat brain: predicted secondary structure and relation to other members of the E-NTPDase family and actin. Purinergic Signalling 1:259-270.

Vulchanova L, Olson TH, Stone LS, Riedl MS, Elde R, and Honda CN (2001) Cytotoxic targeting of isolectin IB4-binding sensory neurons. Neuroscience 108:143-155.

Waeber C and Moskowitz MA (2003) Therapeutic implications of central and peripheral neurologic mechanisms in migraine. Neurology 61:S9-S20.

Wallace DJ (1989) The use of quinacrine (atabrine) in rheumatic diseases: a reexamination. Semin Arthritis Rheum 18:282-296.

Wammack R, Weihe E, Dienes HP, and Hohenfeller R (1995) Die neurogene blase in vitro. Akt Urol 26:16-18.

Wang CM, Chang YY, Kuo JS, and Sun SH (2002) Activation of P2X receptors induced $\left[{ }^{3} \mathrm{H}\right] \mathrm{GABA}$ release from the RBA-2 type-2 astrocyte cell line through a $\mathrm{Cl}^{-} / \mathrm{HCO}_{3}{ }^{-}$-dependent mechanism. Glia 37:8-18.

Wang JC-C, Raybould NP, Luo L, Ryan AF, Cannell MB, Thorne PR, and Housley GC (2003a) Noise induces up-regulation of P2X $\mathrm{X}_{2}$ receptor subunit of ATP-gated ion channels in the rat cochlea. Neuroreport 14:817-823.

Wang L, Andersson M, Karlsson L, Watson MA, Cousens DJ, Jern S, and Erlinge D (2003b) Increased mitogenic and decreased contractile P2 receptors in smooth muscle cells by shear stress in human vessels with intact endothelium. Arterioscler Thromb Vasc Biol 23:1370-1376.

Wang L, Yao H, Yang Y-E, Song I, and Owyang C (2004a) Enhanced purinergic pathway occurs in postoperative ileus: reversal by orphanin FQ. Gastroenterology 126:75

Wang Q, Li X, Wang L, Febg Y-H, Zeng R, and Gorodeski G (2004b) Antiapoptotic effects of estrogen in normal and cancer human cervical epithelial cells. Endocrinology 145:5568-5579.

Watanabe S, Kono Y, Oishi-Tobinaga Y, Yamada S, Hara M, and Kano T (2002) A Comparison of the chronotropic and dromotropic actions between adenosine triphosphate and edrophonium in patients undergoing coronary artery bypass graft surgery. $J$ Cardiothorac Vasc Anesth 16:598-602.

Watanabe S, Yoshimi Y, and Ikekita M (2003) Neuroprotective effect of adenine on Purkinje cell survival in rat cerebellar primary cultures. J Neurosci Res 74:754-759

White N, Ryten M, Clayton E, Butler P, and Burnstock G (2005a) 2Y purinergic receptors regulate the growth of human melanomas. Cancer Lett 224:81-91.

White N, Butler P, and Burnstock G (2005b) Human melanomas express functional $\mathrm{P}_{2} \mathrm{X}_{7}$ receptors. Cell Tissue Res 321:411-418.

Wiley LA, Rupp GR, and Steinle JJ (2005) Sympathetic innervation regulates basement membrane thickening and pericytes number in rat retina. Investig Ophthalmol Vis Sci 46:744-748.

Wirkner K, Koles L, Furst S, and Illes P (2003) Modulation of voltage- and ligandgated ion channels by neuronal P2Y receptors. Drug Dev Res 59:49-55.

Witting A, Walter L, Wacker J, Moller T, and Stella N (2004) P2X 7 receptors control 2-arachidonoylglycerol production by microglial cells. Proc Natl Acad Sci USA 101:3214-3219.

Wu Y, Willcockson HH, Maixner W, and Light AR (2004) Suramin inhibits spinal cord microglia activation and long-term hyperalgesia induced by formalin injection. J Pain 5:48-55.

Wyndaele JJ and De Wachter S (2003) The basics behind bladder pain: a review of data on lower urinary tract sensations. Int J Urol 10 (Suppl):S49-S55.

Wynn G, Bei M, Ruan H-Z, and Burnstock G (2004) Purinergic component of mechanosensory transduction is increased in a rat model of colitis. Am J Physiol 287:G647-G657.

Wynn G, Rong W, Xiang Z, and Burnstock G (2003) Purinergic mechanisms contribute to mechanosensory transduction in the rat colorectum. Gastroenterology 125: 1398-1409.

Xiang Z, Bo X, and Burnstock G (1999) P2X receptor immunoreactivity in the rat cochlea, vestibular ganglion and cochlear nucleus. Hear Res 128:190-196.

Xiang Z and Burnstock G (2004a) Development of nerves expressing P2X $\mathrm{X}_{3}$ receptors in the myenteric plexus of rat stomach. Histochem Cell Biol 122:111-119.

Xiang Z and Burnstock G (2004b) P2X $\mathrm{X}_{2}$ and P2X $\mathrm{X}_{3}$ purinoceptors in the rat enteric nervous system. Histochem Cell Biol 121:169-179.

Xiao HS, Huang QH, Zhang FX, Bao L, Lu YJ, Guo C, Yang L, Huang WJ, Fu G, Xu $\mathrm{SH}$, et al. (2002) Identification of gene expression profile of dorsal root ganglion in the rat peripheral axotomy model of neuropathic pain. Proc Natl Acad Sci USA 99:8360-8365.

Xu J, Chalimoniuk M, Shu Y, Simonyi A, Sun AY, Gonzalez FA, Weisman GA, Wood WG, and Sun GY (2003) Prostaglandin $\mathrm{E}_{2}$ production in astrocytes: regulation by cytokines, extracellular ATP and oxidative agents. Prostaglandins Leukot Essent Fatty Acids 69:437-448.

Xu K, Bastia E, and Schwarzschild M (2005) Therapeutic potential of adenosine $\mathrm{A}_{2 \mathrm{~A}}$ receptor antagonists in Parkinson's disease. Pharmacol Ther 105:267-310.

Yamada T and Chakrabarty AM (2004) ATP-utilizing enzymes, purinergic recerptor modulation, cupredoxins and mammalian cell death, in Pseudomonas (Ramos J-L ed) pp 47-67, Kluwer Academic, New York.

Yamazaki Y, Fujii S, Nakamura T, Miyakawa H, Kudo Y, Kato H, and Ito K (2002) Changes in $\left[\mathrm{Ca}^{2+}\right]_{\mathrm{i}}$ during adenosine triphosphate-induced synaptic plasticity in hippocampal CA1 neurons of the guinea pig. Neurosci Lett 324:65-68.

Yang A, Sonin D, Jones L, Barry WH, and Liang BT (2004) A beneficial role of cardiac $\mathrm{P}_{2} \mathrm{X}_{4}$ receptors in heart failure: rescue of the calsequestrin overexpression model of cardiomyopathy. Am J Physiol 287:H1096-H1103.

Yao ST, Gourine AV, Spyer KM, Barden JA, and Lawrence AJ (2003) Localisation of $\mathrm{P} 2 \mathrm{X}_{2}$ receptor subunit immunoreactivity on nitric oxide synthase expressing neurones in the brain stem and hypothalamus of the rat: a fluorescence immunohistochemical study. Neuroscience 121:411-419.

Yerxa BR (2001) Therapeutic use of nucleotides in respiratory and ophthalmic diseases. Drug Dev Res 52:196-201.

Yerxa BR, Sabater JR, Davis CW, Stutts MJ, Lang-Furr M, Picher M, Jones AC, Cowlen M, Dougherty R, Boyer J, et al. (2002) Pharmacology of INS37217 $\left[\mathrm{P}^{1}\right.$ (uridine $\left.5^{\prime}\right)-\mathrm{P}^{4}-\left(2^{\prime}\right.$-deoxycytidine $\left.5^{\prime}\right)$ tetraphosphate, tetrasodium salt], a nextgeneration $\mathrm{P}_{2} \mathrm{Y}_{2}$ receptor agonist for the treatment of cystic fibrosis. $J$ Pharmacol Exp Ther 302:871-880.

Yiangou Y, Facer P, Baecker PA, Ford AP, Knowles CH, Chan CL, Williams NS, and Anand P (2001) ATP-gated ion channel $\mathrm{P}_{2} \mathrm{X}_{3}$ is increased in human inflammatory bowel disease. Neurogastroenterol Motil 13:365-369.

Yoshida M, Homma Y, Inadome A, Yono M, Seshita H, Miyamoto Y, Murakami S, Kawabe K, and Ueda S (2001) Age-related changes in cholinergic and purinergic neurotransmission in human isolated bladder smooth muscles. Exp Gerontol 36: 99-109.

Yoshida M, Miyamae K, Iwashita H, Otani M, and Inadome A (2004) Management of detrusor dysfunction in the elderly: changes in acetylcholine and adenosine triphosphate release during aging. Urology 63:17-23.

Yu Y and de Groat WC (2004) Sensitization of pelvic afferent nerves in the in vitro urinary bladder-pelvic nerve preparation of the rat by purinergic agonists or by cyclophosphamide (CYP) pre-treatment, in 2004 Abstract Viewer/Itinerary Planner; Program no. 541.3. Society for Neuroscience, Washington, DC

Yusuf S, Zhao F, Mehta SR, Chrolavicius S, Tognoni G, and Fox KK (2001) Effects of clopidogrel in addition to aspirin in patients with acute coronary syndromes without ST-segment elevation. $N$ Engl J Med 345:494-502.

Zablocki J, Kalla R, Perry T, Palle V, Varkhedkar V, Xiao D, Piscopio A, Maa T, Gimbel A, Hao J, et al. (2005) The discovery of a selective, high affinity $\mathrm{A}_{2}$ adenosine receptor antagonist for the potential treatment of asthma. Bioorg Med Chem Lett 15:609-612.

Zhang H-Y, Gu Y-Y, Li Z-G, Jia Y-H, Yuan L, Li S-Y, An G-S, Ni J-H, and Jia H-T (2004a) Exposure of human lung cancer cells to 8-chloro-adenosine induces $\mathrm{G}_{2} / \mathrm{M}$ arrest and mitotic catastrophe. Neoplasia 6:802-812.

Zhang JM, Wang HK, Ye CQ, Ge W, Chen Y, Jiang ZL, Wu CP, Poo MM, and Duan $\mathrm{S}$ (2003) ATP released by astrocytes mediates glutamatergic activity-dependent heterosynaptic suppression. Neuron 40:971-982.

Zhang S, Remillard CV, Fantozzi I, and Yuan JX-J (2004b) ATP-induced mitogenesis is mediated by cyclic AMP response element-binding protein-enhanced TRPC4 expression and activity in human pulmonary artery smooth muscle cells. Am J Physiol 287:C1192-C1201.

Zhang X-J, Zheng G-G, Ma X-T, Yang Y-H, Li G, Rao Q, Nie K, and Wu K-F (2004c) Expression of $\mathrm{P}_{2} \mathrm{X}_{7}$ in human hematpoietic cell lines and leukaemia patients. Leuk Res 28:1313-1322.

Zhao DM, Xue HH, Chida K, Suda T, Oki Y, Kanai M, Uchida C, Ichiyama A, and Nakamura H (2000) Effect of erythromycin on ATP-induced intracellular calcium response in A549 cells. Am J Physiol 278:L726-L736.

Zhu CZ, Mikusa J, Chu KL, Cowart M, Kowaluk EA, Jarvis MF, and McGaraughty S (2001) A-134974: a novel adenosine kinase inhibitor, relieves tactile allodynia via spinal sites of action in peripheral nerve injured rats. Brain Res 905:104-110

Zimmermann H (2001) Ectonucleotidases: some recent developments and a note on nomenclature. Drug Dev Res 52:44-56.

Zona C, Marchetti C, Volontè C, Mercuri NB, and Bernardi G (2000) Effect of P2 purinoceptor antagonists on kainate-induced currents in rat cultured neurons. Brain Res 882:26-35.

Zsembery A, Boyce AT, Liang L, Peti-Peterdi J, Bell PD, and Schwiebert EM (2003) Sustained calcium entry through P2X nucleotide receptor channels in human airway epithelial cells. J Biol Chem 278:13398-13408. 